\title{
Phytoplankton response to fish-induced environmental changes in a temperate shallow pond-type lake
}

\author{
Agnieszka Napiórkowska-Krzebietke
}

Received - 24 August 2017/Accepted - 26 November 2017. Published online: 31 December 2017; @Inland Fisheries Institute in Olsztyn, Poland Citation: Napiórkowska-Krzebietke A. 2017 - Phytoplankton response to fish-induced environmental changes in a temperate shallow pond-type lake - Arch. Pol. Fish. 25: 211-264.

\begin{abstract}
Since 1967, the temperate, shallow, pond-type Lake Warniak has been subjected to different biomanipulation methods including the introduction of common carp, Cyprinus carpio L., grass carp, Ctenopharyngodon idella (Val.), silver carp, Hypophthalmichthys molitrix (Val.), and bighead carp, Hypophthalmichthys nobilis (Richardson) and then their removal in an effort to control macrophytes and phytoplankton. Recently, pilot stocking with predatory fish, particularly pike, Esox lucius L., has also been conducted. Hence, an examination of the long-term response patterns of phytoplankton to multiple fish-induced stressors was undertaken. In recent years, Chara domination (2000-2004) has helped to stabilize a clear-water state, high/good ecological status, and meso-eutrophic conditions. After the disappearance of Charales in 2004, the rapid, unstable changes in phytoplankton biomass, structure, and biodiversity suggested a shift toward a turbid-water state. As a result, the phytoplankton assemblages changed from those dominated by cryptophytes $\mathrm{Y}+\mathrm{X} 2+\mathrm{X} 1+\mathrm{L}_{\mathrm{O}}$ (2000-2004) through those dominated by cyanobacteria K (2005-2008), dinoflagellates $\mathrm{L}_{\mathrm{O}}+\mathrm{Y} \quad$ (2009-2011), and cryptophytes $\mathrm{Y}+\mathrm{L}_{\mathrm{O}}+\mathrm{F}+\mathrm{X} 2$ (2012), to those dominated by diatoms $\mathrm{D}+\mathrm{K}+\mathrm{P}+\mathrm{A}$ (2013-2014) with representative taxa that occur in nutrient-rich and/or nutrient-poor water bodies. The 1967-2014 changes indicated that four periods, two with clear-water state and two with turbid-water state, alternately, one after the other, resulted from different fish pressure. Higher autochthonous fish biomass was usually accompanied
\end{abstract}

A. Napiórkowska-Krzebietke [ $\stackrel{\left.\Xi^{\circ}\right]}{]}$

Department of Ichthyology, Hydrobiology and Aquactic Ecology,

Inland Fisheries Institute in Olsztyn, Poland

e-mail: a.napiorkowska-krzebietke@infish.com.pl by lower phytoplankton biomass. In contrast, the introduction of Cyprinidae fish had a stimulating effect on summer phytoplankton dominated by cyanobateria. Among the nutrients, only phosphorus played an important role.

Keywords: alternative stable states, domination shifts, biomass, cyanobacteria, autochthonous fish, introduced fish

\section{Introduction}

\section{Phytoplankton growth patterns and dominance shifts}

Phytoplankton plays the main role as a primary source of food in both classic and microbial food webs in aquatic ecosystems. High ecological plasticity allows phytoplankton to grow in various environmental conditions, including when external factors (e.g., light, temperature, $\mathrm{CO}_{2}$, nutrients) fluctuate substantially. Phytoplankton seasonal growth patterns can vary significantly, e.g., when trophic levels or the mixing type of lakes differ and under different-sized grazing pressure. The general trend in the seasonal development of phytoplankton includes one, two, or even more, similarly or differently sized peaks of biomass (PEG model; Sommer et al. 1986, Oleksowicz 1988, Brentrup et al. 2016). Rapidly 
increasing grazing associated with late spring zooplankton biomass maximums can occur along with phytoplankton maximums at the end of spring in eutrophic lakes. Thus, such temporal shifts in phytoplankton-zooplankton relations facilitate the occurrence of clear-water state (Talling 2003, Tõnno et al. 2003, Effler et al. 2015), which may not appear in hypertrophic lakes.

Global warming, also referred to as climate change, can also promote phytoplankton growth, structural changes, and dominance shifts toward cyanobacteria species, which are symptoms of progressive eutrophication in shallow lakes (Scheffer et al. 2003, Elliot 2012, Jeppesen et al. 2014, Rigosi et al. 2014). Both global warming and eutrophication can mutually reinforce the symptoms and problems connected with them (Moss et al. 2011). The abundance of relatively small-sized taxa, which also includes cyanobacteria, can increase significantly, while large-sized diatoms decrease because of climate warming (Pulina et al. 2016). Consequently, cyanobacteria species become phytoplankton dominants, and since they are less edible for zooplankton, this can diminish energy flow to higher trophic levels (Elliott 2012).

According to the theory of alternative stable states (Scheffer et al. 1993), one of two states can occur in shallow lakes: a clear-water state with the dominance of submerged macrophytes, or a turbid-water state with the dominance of phytoplankton. The transition from one state to another occurs even without significant changes in nutrient enrichment or specific steady-state assemblages. Shifts between these two alternate states can occur regularly or irregularly without any single critical nutrient level, but other factors, such as lake size or depth and climate change, can affect thresholds (Scheffer and van Nes 2007). However, recent studies have shown that macrophyte loss by shifts from clear-water to turbid-water states can significantly enrich water in nutrients, especially in carbon and phosphorus (with increases in mobile $\mathrm{C}$ and $\mathrm{P}$ of up to two and four times, respectively) stemming from certain decreases in $\mathrm{C}$ and $\mathrm{P}$ storage possibilities
(Wang et al. 2016). The nitrogen content can remain unchanged.

Moreover, according to Rojo and Álvarez-Cobelas (2003), such assemblages are theoretically expected to occur in more stable and unstable, or fluctuating, environments. There are many processes causing assemblage bi-stability, e.g., competitive interactions, mixotrophy, motility, buoyancy regulation, growth rates, and shade adaptation (Naselli-Flores et al. 2003, Salmaso 2003). Other evidence suggests the importance of the food web, especially grazing pressure and mechanisms such as allelopathy, invasions, or even parasitism, in structuring steady-state assemblages. However, turbid-water state can also be enhanced in warmer years (Elliot 2012). The reasons for the establishment of bi-stability assemblages could be of significant help when considering restoration processes of degraded shallow lakes, especially those based on food web manipulations.

\section{Trends in the multiple roles of phytoplankton and solving problems with intense blooms}

The importance of phytoplankton as the basis of food webs in aquatic ecosystems is associated with the unidirectional flow in the nutrient-phytoplankton-zooplankton-fish sequence throughout the successive controls by physical, chemical, and biological processes. All of this determines the proper or improper functioning of the entire lake ecosystem. The important phytoplankton (primary producer) role as a nutritional source of phytonutrients and biologically active compounds in energy-flow pathways is well-documented (Napiórkowska-Krzebietke 2017 and references therein). However, the most important components are the fatty acids (Desvilettes and Bec 2009, Kovač et al. 2013, Sauvanet et al. 2013, Terech-Majewska et al. 2016), while sterols, amino acids, enzymes, organic minerals, chlorophyll, carotenoids, vitamins and trace elements, for example, are also important as they are directly available to the first stages of larval and juvenile fish or even as 
indirect sources through the trophic chain to fish of more advanced stages. Determining phytoplankton structure is also essential for assessing its nutritional value, which has recently been identified as very important for successful aquaculture (Shields and Lupatsch 2012) and even for human nutritional supplementation and health (Abd El Baky and El-Baroty 2013, de Jesus Raposo et al. 2013, Vavilala and D’Souza 2015, Hayes et al. 2017).

Phytoplankton (composition, abundance, and biomass) is a basic biological quality element (BQE) that is required to assess the ecological status of different water bodies as stipulated by the Water Framework Directive (WFD, European Commission 2000). Each European country is obligated to devise its own phytoplankton method, and many methods have been developed and inter-calibrated (Phillips et al. 2014). In Poland, the newly elaborated phytoplankton-based method Phytoplankton Metric for Polish Lakes (PMPL) was tested and compared with the other European methods (Napiórkowska-Krzebietke et al. 2012). Its sensitivity to eutrophication gradients has been studied with positive results. The Polish method has been verified in many lowland, temperate lakes including in smalland medium-sized, shallow and very shallow, stratified and non-stratified, natural and heavily modified Central/Baltic-type (L-CB1 and L-CB2) water bodies (Commission Decision 2013/480/EU). The PMPL method assessed the majority of studied lakes to have a worse than good ecological status; thus, they did not meet the WFD requirements of at least good ecological status (Napiórkowska-Krzebietke et al. 2012, 2016, 2017, Napiórkowska-Krzebietke 2015, Napiórkowska-Krzebietke and Dunalska 2015, Napiórkowska-Krzebietke and Hutorowicz 2014, 2015). Actually, following a positive inter-calibration process, PMPL is regarded as one of the BQEs in the national routine for monitoring water bodies in Poland that is formally regulated by the Regulation of the Minister of the Environment (Regulation 2016). The use of many other phytoplankton indices as water quality indicators, e.g., the algal genus pollution index, the Shannon-Weaver diversity index, the saprobic index, the trophy index, and the new eco-sensitivity factor, were also tested with positive results (Napiórkowska-Krzebietke 2014, 2015, Napiórkowska-Krzebietke et al. 2017).

The intense growth of phytoplankton, primarily cyanobacteria, is usually a nuisance, and it can even be harmful not only for aquatic organisms but also for animals and humans because of the production of cyanotoxins (Kobos et al. 2013). In order to meet WFD goals, intensive phytoplankton blooms cannot be present in surface water bodies. A few biological restoration methods that primarily include removing planktivorous or benthivorous fish, stocking with predatory or herbivorous fish, macrophyte transplantation, or introducing mussels are proposed to control phytoplankton (Jeppesen et al. 2012 and references therein). Thus, some restoration actions, including biomanipulation and planting submerged macrophytes, were taken into account to limit phytoplankton growth (e.g., Yu et al. 2016, Rosińska et al. 2017). A review of the literature on biomanipulation indicates that the results of water quality improvement by reducing phytoplankton quantities can be both positive and negative (Jeppesen et al. 2012, 2014, Ofir et al. 2017). In some cases, biomanipulation leads to significant reductions of nutrients (nitrogen, phosphorus) and chlorophyll $a$ content with increased Secchi disk depth, but in other cases it leads to increased phytoplankton biomass and water quality deterioration. The removal efficiency of nuisance cyanobacteria can be very high (even up to 99.5\%) using multiple treatment technologies that are popular worldwide, e.g., coagulation and sedimentation, dissolved air flotation and rapid sand filtration, lime precipitation, sedimentation and rapid sand filtration, microfiltration and ultrafiltration, and dissolved air flotation and microfiltration (Westrick et al. 2010, Amaral et al. 2013, Huang et al. 2015). Other well-known techniques that have produced promising results include effective microorganisms, barley straw, plant extracts, golden algae, ultrasound, artificial water mixing, and using separators to pre-treat stormwaters in littoral zones in combination with fountain-based aeration in pelagial zones (Lürling et 
al. 2016, Zębek and Napiórkowska-Krzebietke 2016, Sitarek et al. 2017).

\section{Lake Warniak case study and historical outline}

The shallow, pond-type Lake Warniak has been subjected to biomanipulation treatments for many years. It was selected as a model lake for the International Biological Programme (IBP) that ran from 1964 to 1974, and it was included in large-scale biological studies with important scientific implications for humans (Westlake et al. 1998). The problem in Lake Warniak was the high density of macrophytes (13\% emergent and $87 \%$ submerged covering the lake bottom) and low water transparency (Dunst et al. 1974). Thus, one restoration objective was to determine the effect of the introduction of non-native fish species, specifically grass carp, on the biocenosis.

Control catches in Lake Warniak in 1966-1971 indicated the occurrence of 14 autochthonous fish species: Anguilla anguilla (L.); Carassius carassius (L.); Cobitis taenia L.; Esox lucius L.; Gasterosteus aculeatus (L.); Gymnocephalus cernua (L.); Leucaspius delineatus (Heck.); Leuciscus idus (L.); Lota lota (L.); Misgurnus fossilis (L.); Perca fluviatilis L.; Rutilus rutilus (L.); Scardinius erythrophthalmus (L.) and Tinca tinca (L.) (Zawisza and Ciepielewski 1973). The first introduction of the benthophagous Cyprinus carpio L., a non-native, allochthonous fish species, in this lake was in 1967. Next, herbivorous grass carp, Ctenopharyngodon idella (Val.), and seston-feeding Hypophthalmichthys molitrix (Val.) were introduced for the first time in 1970. In the subsequent years (1970-1984), this lake was stocked irregularly with grass carp (C. idella) at varying frequencies and in different amounts (6-1,005 individuals, i.e., 20-1,950 kg per year) (Krzywosz 1997). The maximum biomass stocked was in excess of 6 tons in 1976. This amount decreased in subsequent years for several reasons including progressive natural mortality, growth inhibition, stocking cessation, and overfishing. Seston-feeding carp, or so-called filter feeders, such as silver carp ( $H$. molitrix), which preferentially consumes phytoplankton, and bighead carp, Hypophthalmichthys nobilis (Richardson), which preferentially consumes zooplankton, or both species together with more or less detritus (Conover et al. 2007) were also stocked during this period (Ciepielewski 1985, Białokoz 1997, Zdanowski et al. 1999). Their biomass increased steadily along with stocking rates up to the maximum in 1992, and then it gradually declined from natural mortality, winter fish kills, and intensive exploitation in 1995 and 1997 (Zdanowski et al. 1999). In 2000-2014, Lake Warniak was subjected to experimental pilot stocking primarily with autochthonous predatory fish species (E. lucius and sporadically with A. anguilla and Silurus glanis L.) (Zakęś et al. 2015). During this period, the ichthyofauna comprised 21 species: Abramis brama (L.); Alburnus alburnus (L.); A. anguilla; Blicca bjoerkna L.; Carassius gibelio (Bloch); C. carassius; $C$. idella; E. lucius; G. aculeatus; G. cernua; C. carpio; Gobio gobio L.; H. molitrix; H. nobilis; L. lota; $M$. fossilis; P. fluviatilis; R. rutilus; S. erythrophthalmus; $S$. glanis; T. tinca. In recent years, neither intense exploitation nor winter fish kills have been observed, and oxygen conditions were good for fish survival throughout the year, even during periods of ice-cover (Napiórkowska-Krzebietke et al. 2012, Zakęś et al. 2015, Kalinowska et al. 2017).

Long-term stocking with both herbivorous and seston-feeding fish (primarily C. idella, H. molitrix, and H. nobilis) changed the ecosystem significantly (Dunst et al. 1974, Krzywosz 1997). In 1967-1974, the phytoplankton biomass reached up to approximately $19.5 \mathrm{mg} \mathrm{dm}^{-3}$ (Spodniewska and Hillbricht-Ilkowska 1973, Węgleńska et al. 1979, Zdanowski et al. 1999). After 1975, submerged vegetation disappeared for a period of about 17 years, the trace occurrence of hydrophytes was observed (Hutorowicz and Dziedzic 2008), and the phytoplankton biomass was over two-fold higher (a maximum of $50.0 \mathrm{mg} \mathrm{dm}^{-3}$ in 1978) than it had been in previous years (Krzywosz 1999, Zdanowski et al. 1999). The first symptoms of submerged macrophyte re-establishment were observed in 1993, and in subsequent years their biomass gradually increased to values recorded in the late 1960s and the early 1970s. The biomass of introduced fish declined 
significantly in the late 1990s because of intense fish catches and winter fish kills, and the phytoplankton biomass was again considerably lower, but similar to that recorded in 1967-1974 (Zdanowski et al. 1999). This was followed by gradual macrophyte re-colonization dominated by Charales, primarily Chara globularis Thuiller, C. rudis (A.Braun) Leonhardi, C. contraria A.Braun ex Kützing, $C$. filiformis H.Hertzsch, C. tomentosa Linnaeus, C. aspera C.L.Willdenow and Nitellopsis obtusa (N.A.Desvaux) J.Groves. The maximum growth of charophytes occurred in 2002, but they almost disappeared from the lake in 2005 (Bałdyga 2008). Furthermore, the maximal phytoplankton biomass in 1997-1998 was only approximately $2.0 \mathrm{mg} \mathrm{dm}^{-3}$.

The aim of this study was to determine the response patterns of phytoplankton abundance, structure, and dominance changes to multiple factors in a shallow pond-type lake under different types of fish pressure. The key tasks focused on modelling, classifying, and predicting phytoplankton growth and biodiversity using multi-factorial approaches including bottom-up control by food availability and top-down control by grazing pressure exerted by zooplankton and fish. The analysis of the phytoplankton and the environment comprised primarily current data (2000-2014), but published historical data (1967-1999) was also used to strengthen the phytoplankton response. Therefore, considering the long-term (1967-2014) study period and the data available for comparison, the following hypotheses were formulated for the shallow pond-type lake:

- hypothesis 1: elevated temperature and nutrient enrichment enhance phytoplankton growth and shifts in structure toward cyanobacteria domination;

- hypothesis 2: competition and selective grazing limit phytoplankton growth and biodiversity;

- hypothesis 3: key drivers (factors/species) affect phytoplankton-related changes throughout the ecosystem.

\section{Materials and methods}

\section{Study area}

Lake Warniak is situated in the mesoregion of the Great Masurian Lakeland (northeastern Poland, $\left.54^{\circ} 7^{\prime} 17^{\prime \prime} \mathrm{N} 21^{\circ} 48^{\prime} 4^{\prime \prime} \mathrm{E}\right)$ near the village of Pieczarki about $10 \mathrm{~km}$ north of Giżycko in the drainage basin of Lake Dargin and the catchment area of the Węgorapa River. According to Zakęś et al. (2015), the direct catchment of the lake comprises $70 \%$ forest (gently sloping hills) and 30\% swampy meadows. A constant tributary (northeastern part of the lake) delivers drainage waters from agricultural areas. The main constant outflow in the southern part of lake $\left(0.7 \mathrm{~m}^{3} \mathrm{~min}^{-1}\right)$ discharges water from Lake Warniak into Lake Dgał Wielki, whereas another small outflow in the northwest supplies the drainage system of mid-forest meadows and periodically carries water to Lake Dgał Mały.

Lake Warniak is a small (surface area of 38.4 ha), very shallow (maximum depth of $3.7 \mathrm{~m}$ and mean depth of $1.2 \mathrm{~m}$ ), non-stratified natural water body with a shoreline that has been minimally developed (Table 1). According to fishing use type, it could be a tench-pike lake, which is an experimental lake within the framework of the Department of Sturgeon Fish Breeding of the Inland Fisheries Institute in Olsztyn. According to the index of basin permanence, which is the basin volume to shoreline length ratio (Kerekes 1977), Lake Warniak is almost an extinct lake (pond-like) with the shoreline zone exerting a strong effect on basin volume. The lake bottom in both the shoreline and open water zones is composed of residual sediment of limestone origin. The shoreline zone of the lake, similarly as reported by Napiórkowska-Krzebietke et al. (2012), is still dominated by emerged vegetation. The dominant helophyte species of Phragmites australis (Cav.) Trin. ex Steud, Typha latifolia L., Schoenoplectus lacustris (L.) Palla, Acorus calamus L. and floating-leaved species of the genus Nuphar cover nearly the entire lake shoreline and exhibit a clear tendency of expanding their distribution. In certain period, the open water 
Table 1

Morphometric parameters of Lake Warniak

\begin{tabular}{ll}
\hline \hline Parameters & \\
\hline \hline Geographical coordinates & $54.717 \mathrm{~N}, 21.484 \mathrm{E}$ \\
Surface area $\left(\mathrm{km}^{2}\right)$ & 0.384 \\
Maximal depth $(\mathrm{m})$ & 3.7 \\
Mean depth $(\mathrm{m})$ & 1.2 \\
Relative depth $(\mathrm{m})$ & 1.24 \\
Volume $\left(\times 10^{3} \mathrm{~m}^{3}\right)$ & 456.7 \\
Maximal length $(\mathrm{m})$ & 1000 \\
Maximal width $(\mathrm{m})$ & 500 \\
Shore length $(\mathrm{m})$ & 2625 \\
Shoreline development & 1.20 \\
Development of volume & 0.97 \\
Index of basin performance & 0.17 \\
Shore length to area ratio & 6.84 \\
Catchment area $\left(\mathrm{km}^{2}\right)^{\mathrm{b}}$ & 9.134 \\
Schindler index & 20 \\
Type of stratification & polimictic \\
Static type & I \\
Fishing use type $^{\mathrm{c}}$ & tench-pike \\
\hline
\end{tabular}

a the ratio of basin volume to shoreline length

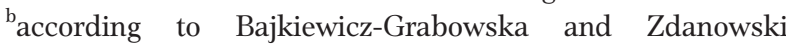
(unpublished data)

'the ratio of catchment area (plus surface area) to the lake's volume

zone was overgrown by submerged macrophytes. In 1967-1974, the lake bottom was overgrown with the angiosperms Elodea canadensis Michx., Ceratophyllum demersum L., Stratiotes aloides L. After 1993, several tons of plant material dominated by E. canadensis were transplanted from Lake Dargin, and as a result only charophytes began to cover the lake bottom. The period with dense submerged macrophytes lasted until 2004 (Bałdyga 2008, Hutorowicz and Dziedzic 2008). In 2005, charophytes suddenly almost disappeared and other submerged macrophytes formed only residual phytocoenoses (Bałdyga 2008) or occurred only as single specimens; there were primarily of the genus Potamogeton, and they were rarely observed in subsequent years (2005-2014) or recently (Jurkiewicz-Karnkowska et al. 2017, K. Stawecki and B. Zdanowski - personal communication). This all indicates a certain stage of the natural process of lake extinction accelerated by human activity (e.g., fisheries management and experimental stocking with grass carp, silver carp, and bighead carp).

\section{Fish stocking, catches, and biomass}

Historically, different fish species were introduced outside their native range into Lake Warniak in 1967-1984, and after 1987 (Tables 2-3). In 1967-1969, the lake was experimentally stocked primarily with common carp. After winter fish kills in February 1970 that affected stickleback, rudd, common carp, and tench (Zachwieja 1973), the lake was stocked primarily with grass carp, silver carp, and bighead carp (1970-1984). In the late 1980s and in the 1990 s, stocking was very infrequent. The most intense catches were carried out in 1995 and 1997 (Zdanowski et al. 1999). In the current study period of 2000-2014, Lake Warniak was experimentally stocked (mainly for a pilot study) with autochthonous predatory fish species. In 2000-2010, pike was stocked for nine years, and both wels catfish and $\mathrm{Eu}-$ ropean eel were stocked for three years (Zakęś et al. 2015, Table 3). In subsequent years (2011-2014), the lake was stocked experimentally only with pike fry that had been reared in recirculating aquaculture systems as this is a key species that regulates the classic food web in lakes. Three different sizes of stocking material were released: small (approximate body length of $6.3 \mathrm{~cm}$, body mass of $2.2 \mathrm{~g}$ ); medium (approximately $8.7 \mathrm{~cm}, 6.0 \mathrm{~g}$ ); large (approximately $12.7 \mathrm{~cm}, 17.1 \mathrm{~g}$ ). Generally, the pike should have had good environmental conditions for natural reproduction and the growth of juvenile stages in this lake. However, monitoring and experimental fish catches in 2011-2014 indicated that stocked pike, which had been tagged before release, were caught only occasionally in this lake; this probably could have stemmed from the fish not yet having reached catch size (Zakęś et al. 2015).

In 2000-2013, fish catches were not regular, but they were highly differentiated, with peaks in 2001 and 2005 (Zakęś et al. 2015). In 2003, 2007-2009, 
Table 2

Historical data on experimental introduction of allochthonous fish species for Lake Warniak in 1967-1999

\begin{tabular}{llll}
\hline \hline & \multicolumn{2}{l}{ Fish species $\left(\mathrm{kg} \mathrm{ha}^{-1}\right)$} & $\begin{array}{l}\text { Silver carp + } \\
\text { Years of stock- }\end{array}$ \\
\cline { 2 - 4 } ings & Common carp & Grass carp & barp \\
\hline 1967 & 36.4 & - & - \\
1968 & 46.9 & - & - \\
1969 & 5.6 & - & - \\
1970 & 7.1 & 6.8 & 1.1 \\
1971 & - & 25.2 & - \\
1973 & 31.3 & 50.8 & 7.3 \\
1975 & - & 10421 & $1563^{1}$ \\
1976 & 62.3 & 23.8 & 26.6 \\
1977 & 14.3 & 4.4 & - \\
1978 & 6.8 & 0.8 & - \\
1981 & 4.0 & - & 20.1 \\
1982 & 2.5 & - & 13.0 \\
1984 & - & - & 52.1 \\
1985 & - & - & 0.1 \\
1988 & 2.3 & - & - \\
\hline \hline
\end{tabular}

- means no introduction of these species, ${ }^{1}$ stocking rate (ind. $\mathrm{ha}^{-1}$ )

Data according to Zawisza and Ciepielewski (1973), Krzywosz (1997), Zdanowski et al. (1999), Hutorowicz and Dziedzic (2008)

and 2012 no fish catches were made in this lake, and in the remaining years the average annual yield of fish catches was approximately $11.1 \mathrm{~kg} \mathrm{ha}^{-1}$. At this time, fish biodiversity was relatively high (21 species), and the species caught most frequently were $A$. brama, H. molitrix, H. nobilis, $R$. rutilus, and $E$. lucius, the percentage share of which in the total catches ranged from $19 \%$ to $26 \%$.

Generally, long-term experimental fish introduction and stocking events in Lake Warniak included primarily the following:

1. benthophagous common carp (1967-1970);

2. herbivorous grass carp (1970-1978);

3. seston-feeding silver carp and bighead carp (1970-1985);

4. benthophagous common carp (irregularly in 1973-1988) and predatory pike and European eel (very rarely and irregularly in 1981-1999);

5. only predatory fish, primarily pike and sporadically wels catfish and European eel (only autochthonous fish, 2000-2014).
Table 3

Stocking Lake Warniak with autochthonous fish species in 2000-2014

\begin{tabular}{llll}
\hline \hline Fish species & Years of stocking & $\begin{array}{l}\text { Stocking rate } \\
\text { (ind. ha }{ }^{-1} \text { ) }\end{array}$ & $\begin{array}{l}\text { Assortment/size } \\
\text { group }\end{array}$ \\
\hline \hline \multirow{2}{*}{ Pike } & $2000-2005$, & $260-651$ & hatchlings \\
& $2008-2010$ & & summer fry \\
& 2004 & 2 & fall fry \\
& 2005 & 4 & RAS reared fry \\
& $2011-2014$ & 45 & fall fry \\
Wels catfish & 2002,2008, & $20-299$ & \\
& 2010 & & reared fry \\
European eel & 2005,2006, & $0.03-0.04^{1}$ & \\
& 2009 &
\end{tabular}

${ }^{1}\left(\mathrm{~kg} \mathrm{ha}^{-1}\right)$, RAS - recirculating aquaculture systems

Data according to Zakęś et al. (2015)

Since each group of fish introduced was characterized by a different diet type, developmental stage, or body size (e.g., hatchlings, fry), the impact of these groups on the whole aquatic ecosystem began with the primary consumers (herbivores) through secondary consumers and predators (carnivores and omnivores), and finally, participation in nutrient circulation.

After its introduction into Lake Warniak, grass carp, which is the main species that directly influences macrophyte biomass, gradually increased in biomass and reached approximately $140 \mathrm{~kg} \mathrm{ha}^{-1}$ in 1976, and then its biomass gradually decreased in subsequent years (Krzywosz 1997, Zdanowski et al. 1999). Simultaneously, common carp attained a biomass of up to $115 \mathrm{~kg} \mathrm{ha}^{-1}$. The distinctly high biomasses of these two species were still recorded in 1973-1978. After ending grass carp stocking and following winter fish kills in February 1985 and 1987, its biomass decreased drastically to very low level. After 1984 despite these winter fish kills, a systematically increasing trend in silver carp and bighead carp biomass was noted until 1992 (with a maximum in excess of $600 \mathrm{~kg} \mathrm{ha}^{-1}$ ). The oxygen demands of these species are more or less comparable to those of grass carp or common carp, but they do vary substantially with fish age and size and water temperature. Furthermore, asphyxiation occurs at water oxygenation levels of $0.3 \mathrm{mg} \mathrm{dm}^{-3}$ for common carp, $0.4 \mathrm{mg} \mathrm{dm}^{-3}$ 


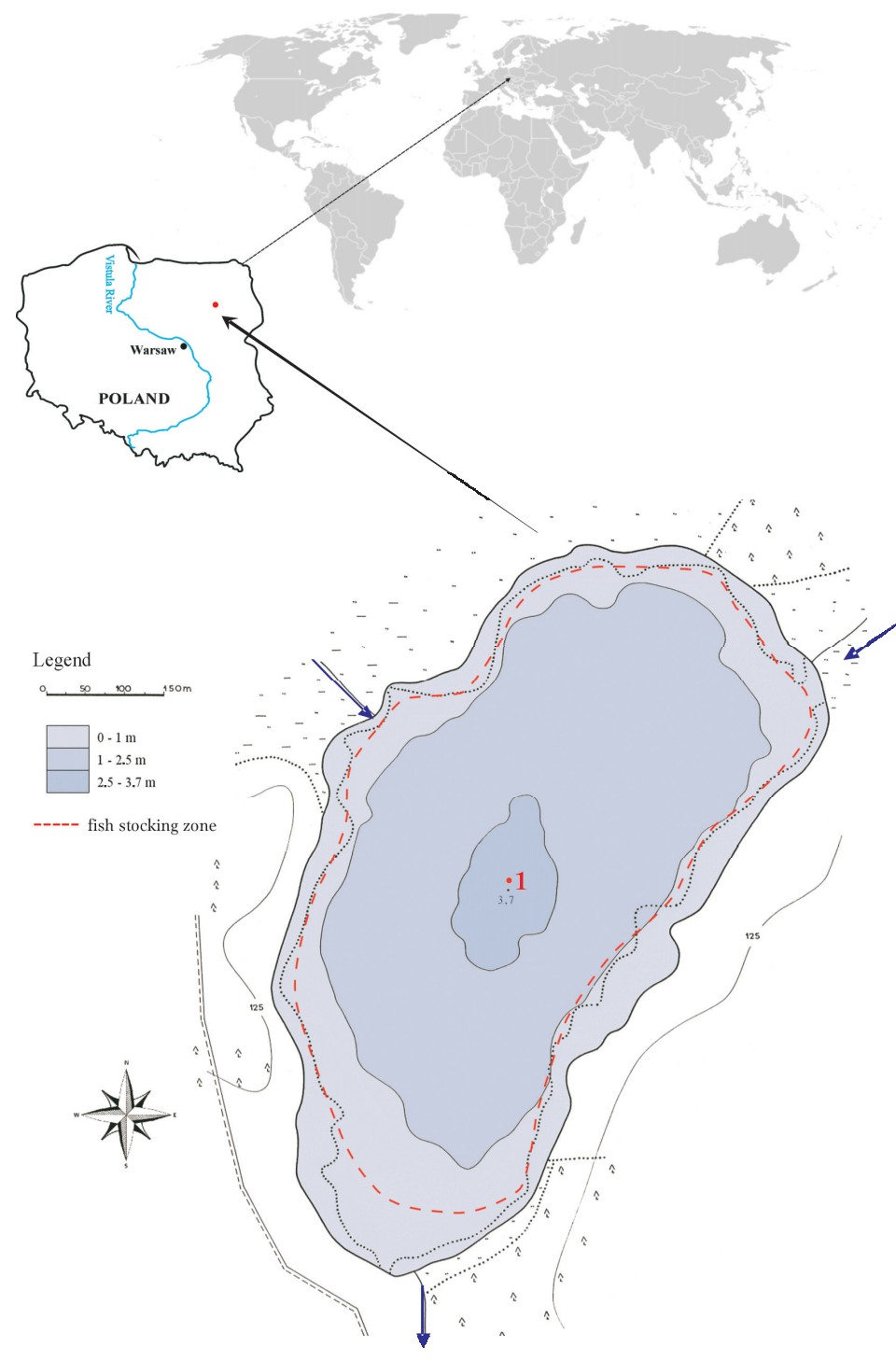

Figure 1. Location of Lake Warniak and standard monitoring site of phytoplankton and environmental variables (1); bathymetric plan of Lake Warniak according to IFI in Olsztyn (modified), dashed red line indicates fish stocking zone after 2000 (Zakęś et al. 2015), arrows indicate inflows and outflow.

for grass carp, and bighead carp, and of $0.8 \mathrm{mg} \mathrm{dm}^{-3}$ for silver carp (Fei 1989). After 1992, a systematically decreasing trend was recorded in the following years. From the late 1970 s to the 1990 s, the biomass of autochthonous fish was significantly reduced (up to half), and after 1995 their populations started to increase to approximately $200 \mathrm{~kg} \mathrm{ha}^{-1}$ (Zdanowski et al. 1999, Chybowski, unpublished data).

\section{Sampling and quantitative and qualitative analyses of phytoplankton}

The deepest point in the lake was chosen as the representative sampling site, i.e., the standard monitoring site (Fig. 1). The phytoplankton samples were collected at 1 $m$ intervals from the surface to the bottom (0-3 m), and then they were integrated. The sampling period included entire growth seasons (the ice-free period from March when ice cover melted to November when thin ice cover formed) from each year of the 15-year study (2000-2014). Additionally, some samples were also collected in late February at the end of ice-cover period at the moment just before the spring phytoplankton growth stage. Two kinds of samples were collected: integrated samples that were preserved with formalin and glycerine water for quantitative analysis and live samples for phytoplankton qualitative analysis collected with $10 \mu \mathrm{m}$ mesh size net.

Both quantitative and qualitative analyses of microplankton and nannoplankton were performed according to CEN standards (EN 14996, EN 15204, PN-EN 15204:2006, DIN CEN 2015) that are required for phytoplankton monitoring under the European Water Framework Directive. Quantitative phytoplankton analysis was conducted using inverted microscope according to the generally accepted standard Utermöhl method (Utermöhl 1958, Kelly 2004, CEN EN 15204, 2006). Individuals (single cells, coenobia, colonies, filaments) were counted in sedimentation chambers $(10 \mathrm{~mL})$ at varied magnifications, i.e., large taxa in the whole chamber using 100x, medium-sized taxa in 2-4 strips using 200x, and nannoplankton in 100 fields using 400x. Phytoplankton biomass was calculated using cell biovolume measurements (Pliński et al. 1984) and verified according to the latest DIN CEN standards (DIN CEN 2015, Napiórkowska-Krzebietke and 
Kobos 2016). Qualitative analysis was conducted using light microscope at magnifications of $\times 200$, $\times 400$, and $\times 1000$ with oil immersion. Taxa identification was based on current references (e.g., Huber-Pestalozzi 1983, Krammer and Lange-Bertalot 1986, 1988, 1991, Komárek and Anagnostidis 1999, 2005), and recognized taxonomic names were confirmed at AlgaeBase (Guiry and Guiry 2017).

\section{Environmental variables}

The water temperature and dissolved oxygen content were measured with YSI 6600-meters (USA), and transparency was determined with the Secchi disk method in the field during phytoplankton sampling. Water samples for chemical analysis were also collected simultaneously, and these were analysed in the laboratory according to standard methods (PN-EN ISO 6878:2006p.7, PN-EN 25663:2001, PN-ISO 10260:2002, PN-86/C-05560.02; Standard Methods 1999). Nitrate concentrations were determined with high performance liquid ion chromatography (Shimadzu Prominence HPLC System). Total phosphorus, phosphates, and ammonium nitrogen were measured colorimetrically with a Shimadzu UV 1601 spectrophotometer, and total nitrogen and nitrites were measured with an Epoll ECO 20 spectrophotometer. Chlorophyll $a$ content was analysed with the method proposed by Lorenzen (1967, PN-86/C-05560.02).

The unpublished and partially published data on thermal, oxygen, and nutrient conditions in the water, meteorological data (air temperature and precipitation), and fish biomass data from 2000-2014 were obtained from the Inland Fisheries Institute in Olsztyn. This paper also refers to a previous study period to present multi-year changes based on historical data from 1967-1999 and current data from 2000-2014, including both published and unpublished data. Selected general data on phytoplankton biomass and its structure in 2000-2008 were presented as posters during phycological and botanical conferences (Napiórkowska-Krzebietke and Hutorowicz, unpublished data, Napiórkowska-Krzebietke, Bałdyga, Hutorowicz, unpublished data).

\section{Multiple approaches in assessing phytoplankton response to fish-induced environmental changes}

Selected indices, both existing and new with newly proposed classifications, were applied to assess phytoplankton response to fish-induced environmental changes.

1. Phytoplankton biodiversity included species richness (S), which was expressed as the total number of taxa, the Shannon-Weaver diversity index (S-WI, Shannon, Weaver 1949), and Pielou's evenness index (E, Pielou 1966), which were calculated using taxa biomass.

2. Functional classification included the assignment of dominant species, those which contributed at least $5 \%$ to the total biomass, to functional groups (coda) according to Reynolds et al. (2002) and Padisák et al. (2009). This concept was applied to describe phytoplankton patterns in the commonly shared adaptive features of various aquatic ecosystems that permitted allocating species to suitable habitat templates.

3. Eco-sensitivity factor (E-SF), i.e., the biomass ratio of all tolerant (T - tolerant, VT - very tolerant) to sensitive ( $\mathrm{S}$ - sensitive, VS - very sensitive) taxa (Napiórkowska-Krzebietke et al. 2017) based on concept of the Phytoplankton Trophic Index (PTI, Phillips et al. 2013). This refers to trophic scores of taxa combined with eutrophication gradients expressed as total phosphorus. The formula used for calculations (equation 1) follows:

$$
E-S F=(T+V T) /(S+V S)
$$

4. PMPL ${ }_{M O D}$ - the modified Phytoplankton Metric for Polish Lakes, which comprises the two partial metrics of MTB (metric "Total Biomass") and MBC (metric "Biomass of Cyanobacteria“) according to Napiórkowska-Krzebietke (2015), was used to determine long-term changes in the ecological status of the lake. 
5 . The potential zooplankton biomass (PZB) in summer 2000-2014 was calculated using a formula (equation 2) that describes the linear relationship between average long-term summer data on total phytoplankton biomass (TB) and total zooplankton biomass in 1967-1998 (according to Spodniewska and Hillbricht-Ilkowska 1973, Węgleńska et al. 1979, Krzywosz 1999, Zdanowski et al. 1999, Tunowski 2006, 2008). It was assumed that this relationship was significant at the level of $\alpha=0.05$ for $n=18$.

$$
\begin{gathered}
P Z B=0.2484 \times T B+0.4573 \\
r=0.495
\end{gathered}
$$

6. Trophic efficiency, which describes the ratio of zooplankton biomass to phytoplankton biomass (according to Hilbricht-Ilkowska and Kajak 1986), was used for the summer data. A new trophic efficiency classification was proposed and it ranges from the lowest to the highest efficiency, i.e., class I - 0-0.20, class II - 0.21-0.40, class III - 0.41-0.60, class IV - 0.61-0.80 and class V - 0.81-1.00.

7. The trophic state of the lake was determined with the Trophic Level Index (TLI, Burns et al. 1999), which considers seasonal data on Secchi disk depth (SDD), total phosphorus (TP), chlorophyll $a(\mathrm{Chl})$, and total nitrogen (TN) as follows (equation 3):

$$
T L I=\left(T L I_{S D D}+T L I_{T P}+T L I_{C h l}+T L I_{T N}\right) / 4
$$

The TLI was used instead of the well-known Carlson's TSI (Trophic State Index), because it encompasses variations of trophic parameters throughout the growth seasons, and not only in summers as is the case with the TSI. However, the two indices are very closely related, and they can be used interchangeably to evaluate lake trophic state (Napiórkowska-Krzebietke et al. 2013).

8. Fish pressure was based on biomass data (according to Zdanowski et al. 1999, and Chybowski, unpublished data) of selected fish groups, and it was calculated as the percentage share (\%) of total biomass. The type of fish pressure was proposed based on the domination of certain fish groups, i.e., their relative biomass. Prominent domination was at $>70 \%$ of total biomass, whereas co-domination was over $40 \%$; this determined the type of fish pressure.

Phytoplankton-macrophyte relationships provided the basis for analyzing the role of competition. Phytoplankton-zooplankton and phytoplankton-zooplankton-fish relationships were used to determine the role of grazing in the lake.

\section{Statistical analysis}

Modelling seasonal changes in phytoplankton biomass was based on transformed data of total biomass and the biomass of particular phyla in two main periods. The first period was from 2000 to 2004 when submerged macrophytes (primarily Charales Chara globularis and C. rudis) dominated distinctly, and the second period was from 2005 to 2014 when phytoplankton dominated, Charales disappeared, and there were residual macrophyte phytocoenoses. Therefore, the relative phytoplankton biomass was calculated based on the division of each biomass value by the maximum biomass for the entire study period (2000-2014). The same procedures were applied to obtain transformed data on relative phytoplankton species richness and diversity. Exceptionally, two maximums were noted in phytoplankton structure; the first was in 2000-2004 and the second was in 2005-2014. These were used to increase readability. The pattern of changes in seasonal phytoplankton growth, structure, and biodiversity were then obtained using statistical tools to select the optimal trend lines in the polynomial method that had the best fit to the series of data points. The same procedure to model seasonal phytoplankton growth dynamics was for the 1967-1974 period based on published data (Spodniewska and Hilbricht-Ilkowska 1973, Spodniewska 1975, Węgleńska et al. 1979).

The non-parametric Mann-Whitney U test and the Kruskal-Wallis test were used to compare two and more than two independent groups (phytoplankton groups based on biomass, and physicochemical variables), respectively 
(STATISTICA v. 12). Hierarchical cluster analysis using the Unweighted Pair Group Method with Arithmetic Mean (UPGMA) that reflected the phytoplankton structure in pairwise similarity matrixes (Percent Similarity) (Multi-Variate Statistical Package, MVSP, Kov. Comp. Serv. 1985-2009) was applied to determine the similarity of phytoplankton assemblages. The coefficient of variation $(\mathrm{CV}$, expressed in \%) was calculated to characterize selected physicochemical and phytoplankton variables.

Phytoplankton was correlated with environmental variables using the Spearman rank coefficient non-parametric method because of a lack of normally distributed data. Additionally, principal component analysis (PCA), original and after applying orthogonal varimax rotation (maximizing the sum of the variances of the squared loadings; Kaiser 1958), was used to strengthen the interpretation in phytoplankton-environment relations (STATISTICA v.12). The so-called Kaiser's (1960) criterion, i.e., an eigenvalue-greater-than-one rule, was applied to interpret the results. Canonical correspondence analysis (CCA) was also used to confirm these relationships. The Monte Carlo test with 999 random permutations $(\mathrm{P}<0.05)$ was then applied as a forward selection procedure to reduce the number of variables. CCA results were illustrated in biplot graphs using Canoco for Windows 4.5 software. A regression model was used to obtain possible estimations and/or predictions of expected fish biomass along with summer phytoplankton biomass that included fish data (Zdanowski et al. 1999, Chybowski, unpublished data) and phytoplankton data (Spodniewska and Hilbricht-Ilkowska 1973, Spodniewska 1975, Węgleńska et al. 1979, Zdanowski et al. 1999, this study) in 1967-2014.

\section{Results}

\section{Environmental variables}

The average annual air temperature (AAAT) in $2000-2014$ was $8.4^{\circ} \mathrm{C}$, and it increased by $1.5^{\circ} \mathrm{C}$ compared with the previous period of 1953-1999 when the mean temperature was $6.9^{\circ} \mathrm{C}$ (data from Napiórkowska-Krzebietke 2004). After 2000, annual deviations from the 46-year (1953-1999) AAAT were positive at an amplitude of $0.3-2.2^{\circ} \mathrm{C}$ throughout the studied period (Fig. 2a). The highest deviations (over $2^{\circ} \mathrm{C}$ ) were recorded in 2002, 2007, 2008, and 2014, whereas the lowest was in 2010. When considering the seasons in detail, the deviations were almost always positive for spring, summer, and fall. The sum of the average annual precipitation (AAPS) was $625.8 \mathrm{~mm}$ in 2000-2014, which was slightly lower than the 1953-1999 mean sum of $636.8 \mathrm{~mm}$.
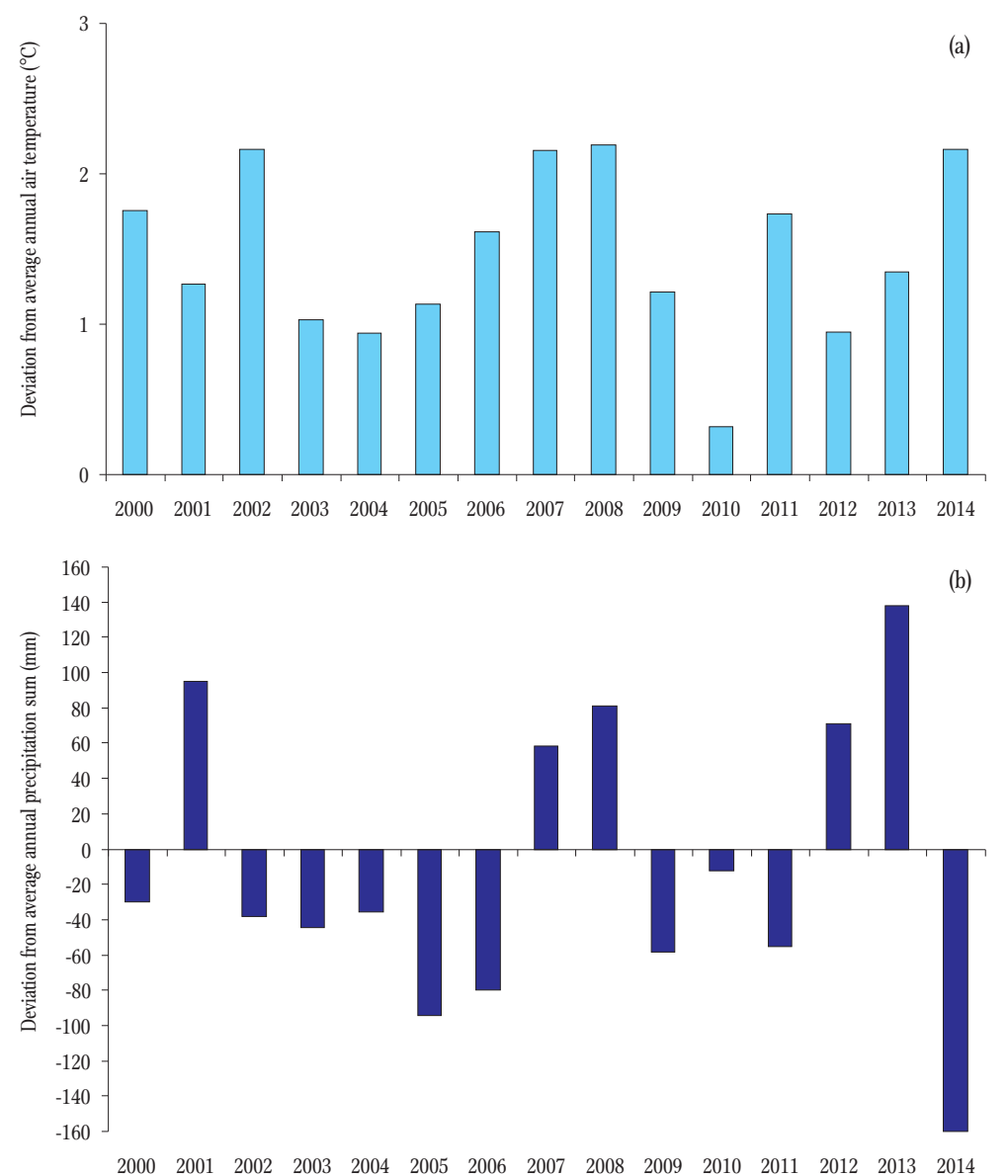

Figure 2. Deviations from the $1953-1999$ mean annual air temperature of $6.9^{\circ} \mathrm{C}$ (a) and precipitation sum of $636.8 \mathrm{~mm}(\mathrm{~b})$. 
Table 4

Selected physicochemical parameters (average seasonal data \pm SD and coefficient of variation CV, \%) in Lake Warniak in 2000-2004 and 2005-2014

\begin{tabular}{|c|c|c|c|c|}
\hline \multirow[b]{2}{*}{ Variables } & \multicolumn{2}{|l|}{$2000-2004$} & \multicolumn{2}{|l|}{$2005-2014$} \\
\hline & Mean \pm SD & CV (\%) & Mean \pm SD & CV (\%) \\
\hline $\mathrm{T}\left({ }^{\circ} \mathrm{C}\right)$ & $14.6 \pm 7.4$ & 50 & $15.7 \pm 7.5$ & 48 \\
\hline $\mathrm{DO}\left(\mathrm{mg} \mathrm{dm}^{-3}\right)$ & $10.9 \pm 1.9$ & 17 & $10.2 \pm 1.9$ & 18 \\
\hline Oxygen saturation (\%) & $105.4 \pm 18.1$ & 17 & $102.6 \pm 23.4$ & 23 \\
\hline $\operatorname{SDD}(m)$ & $2.5 \pm 0.5$ & 22 & $1.9 \pm 0.8$ & 40 \\
\hline Chl- $a\left(\mu \mathrm{g} \mathrm{dm}{ }^{-3}\right)$ & $8.1 \pm 5.0$ & 61 & $12.4 \pm 8.9$ & 72 \\
\hline $\mathrm{TP}\left(\mathrm{mg} \mathrm{dm}^{-3}\right)$ & $0.080 \pm 0.036$ & 46 & $0.092 \pm 0.033$ & 36 \\
\hline $\mathrm{PO}_{4}-\mathrm{P}\left(\mathrm{mg} \mathrm{dm}^{-3}\right)$ & $0.016 \pm 0.015$ & 93 & $0.025 \pm 0.012$ & 47 \\
\hline $\mathrm{P}_{\text {org }}\left(\mathrm{mg} \mathrm{dm}^{-3}\right)$ & $0.064 \pm 0.027$ & 43 & $0.067 \pm 0.033$ & 49 \\
\hline $\mathrm{TN}\left(\mathrm{mg} \mathrm{dm}^{-3}\right)$ & $1.292 \pm 0.515$ & 40 & $1.150 \pm 0.391$ & 34 \\
\hline $\mathrm{NH}_{4}-\mathrm{N}\left(\mathrm{mg} \mathrm{dm}^{-3}\right)$ & $0.181 \pm 0.084$ & 46 & $0.153 \pm 0.118$ & 77 \\
\hline $\mathrm{NO}_{2}-\mathrm{N}\left(\mathrm{mg} \mathrm{dm}^{-3}\right)$ & $0.009 \pm 0.007$ & 71 & $0.006 \pm 0.004$ & 65 \\
\hline $\mathrm{NO}_{3}-\mathrm{N}\left(\mathrm{mg} \mathrm{dm}^{-3}\right)$ & $0.087 \pm 0.085$ & 97 & $0.087 \pm 0.109$ & 125 \\
\hline $\mathrm{N}_{\text {org }}\left(\mathrm{mg} \mathrm{dm}^{-3}\right)$ & $1.017 \pm 0.401$ & 39 & $0.914 \pm 0.365$ & 40 \\
\hline TN:TP ratio & 16 & - & 13 & - \\
\hline
\end{tabular}

SD - standard deviation, T - water temperature, DO - dissolved oxygen, SDD - Secchi disk depth, Chl- $a$ - chlorophyll $a$, TP - total phosphorus, $\mathrm{PO}_{4}-\mathrm{P}$ - phosphates, $\mathrm{P}_{\text {org }}$ - organic phosphorus, $\mathrm{TN}$ - total nitrogen, $\mathrm{NH}_{4}-\mathrm{N}$ - ammonium nitrogen, $\mathrm{NO}_{2}-\mathrm{N}$ - nitrite nitrogen, $\mathrm{NO}_{3}-\mathrm{N}$ - nitrate nitrogen, $\mathrm{N}_{\text {org }}$ - organic nitrogen.

Database also includes partially published data (Napiórkowska-Krzebietke et al. 2012, Zakęś et al. 2015).

The amplitude of deviations from AAPS was high (from -160 to $+138 \mathrm{~mm}$ ) (Fig. $2 \mathrm{~b}$ ). Ten years were characterized by negative deviations (less precipitation) and five years by positive deviations (more precipitation). The wettest year was 2013 and the driest year was 2014.

Considerable variation in physicochemical variables from period to period was observed in Lake Warniak (Table 4). The higher mean Secchi disk depth was accompanied by lower chlorophyll $a$ contents in 2000-2004 than in 2005-2014. The only the slight tendency toward lower contents of total phosphorus and phosphate and higher contents of total nitrogen and mineral nitrogen were in the first period, but not in the second. The coefficient of variation was the highest at up to $125 \%$ for nitrates in both periods. The concentration of dissolved oxygen had the lowest CV at $17 \%$. Compared with earlier data (Table 5; data from 1967-1998 according to Zachwieja 1973, Spodniewska and Hilbricht-Ilkowska 1973, Węgleńska et al. 1979, Karpiński 1994, Zdanowski et al. 1999), Secchi disk depth was one of the most variable parameters and fluctuated on average as follows: $2.7 \mathrm{~m}$ in 1967-1974; $1.0 \mathrm{~m}$ in $1975-1984 ; 1.3 \mathrm{~m}$ in 1985-1994; $2.3 \mathrm{~m}$ in 1995-1998; $2.5 \mathrm{~m}$ in 2000-2004; $1.9 \mathrm{~m}$ in 2005-2014. The differences among the first three periods and the 2000-2004 period were significant. The concentrations of chlorophyll $a$, TP, and TN decreased from $24.8 \mu \mathrm{g} \mathrm{dm}^{-3}$ to $8.1 \mu \mathrm{g} \mathrm{dm}^{-3}$ (significantly), from $0.100 \mathrm{mg} \mathrm{dm}^{-3}$ to $0.070 \mathrm{mg} \mathrm{dm}^{-3}$ and from 1.6 to $1.2 \mathrm{mg} \mathrm{dm}^{-3}$, on average, respectively. The average seasonal water temperature in 1967-1998 ranged from $12.1^{\circ} \mathrm{C}$ to $13.7^{\circ} \mathrm{C}$, whereas it was $14.6^{\circ} \mathrm{C}$ and $15.7^{\circ} \mathrm{C}$, on average, in $2000-2004$ and 2005-2014, respectively. The concentration of dissolved oxygen and $\mathrm{pH}$ were similar throughout the period analysed, and the averages were $10.6 \mathrm{mg}$ $\mathrm{dm}^{-3}$ and 8.2 , respectively. The alkalinity and conductivity results were similar, with average values of $2.6 \mathrm{mval} \mathrm{dm}^{-3}$ and $278 \mu \mathrm{S} \mathrm{cm}^{-1}$, respectively, in 1967-2004, but higher values of $3.8 \mathrm{mval} \mathrm{dm}^{-3}$ and $342 \mu \mathrm{S} \mathrm{cm}{ }^{-1}$, respectively, were recorded in 2005-2014. Long-term changes in total seston content were very similar to those in chlorophyll a content. The highest value of $29.0 \mathrm{mg} \mathrm{dm}^{-3}$ was also 
Table 5

Selected environmental variables (average seasonal data) in Lake Warniak in 1967-2014

\begin{tabular}{|c|c|c|c|c|c|c|c|c|c|c|}
\hline & $\mathrm{T}$ & DO & & SDD & Chl- $a$ & $\mathrm{TN}$ & $\mathrm{TP}$ & ALK & COND & SES \\
\hline Periods & $\left({ }^{\circ} \mathrm{C}\right)$ & $\left(\mathrm{mg} \mathrm{dm}^{-3}\right)$ & $\mathrm{pH}$ & (m) & $\left(\mu \mathrm{g} \mathrm{dm}{ }^{-3}\right)$ & $\left(\mathrm{mgdm} \mathrm{d}^{-3}\right)$ & $\left(\mathrm{mg} \mathrm{dm}^{-3}\right)$ & $\left(\mathrm{mval} \mathrm{dm}^{-3}\right)$ & $\left(\mu \mathrm{S} \mathrm{cm}^{-1}\right)$ & $\left(\mathrm{mg} \mathrm{dm} \mathrm{m}^{-3}\right)$ \\
\hline $1967-1974$ & 12.1 & 10.4 & 7.8 & $2.7^{\mathrm{ab}}$ & n.d. & n.d. & 0.060 & 2.7 & 275 & n.d. \\
\hline $1975-1984$ & 13.7 & 10.8 & 8.2 & $1.0^{\mathrm{ac}}$ & $24.8^{\mathrm{ef}}$ & 1.6 & 0.100 & 2.7 & 272 & 29.0 \\
\hline $1985-1994$ & 12.3 & 10.6 & 8.1 & $1.3^{\mathrm{bd}}$ & 18.4 & 1.6 & 0.080 & 2.6 & 291 & 7.8 \\
\hline 1995-1998 & 13.5 & 10.5 & 8.4 & 2.3 & 8.6 & 1.4 & 0.070 & 2.5 & 274 & 4.3 \\
\hline $2000-2004$ & 14.6 & 10.9 & 8.3 & $2.5^{\mathrm{cd}}$ & $8.1^{\mathrm{e}}$ & 1.3 & 0.080 & 2.3 & n.d. & n.d. \\
\hline 2005-2014 & 15.7 & 10.2 & 8.2 & 1.9 & $12.4^{\mathrm{f}}$ & 1.2 & 0.092 & 3.8 & 342 & 5.3 \\
\hline
\end{tabular}

$\mathrm{T}$ - water temperature, DO - dissolved oxygen, $\mathrm{pH}$ - potential of hydrogen, SDD - Secchi disk depth, Chl- $a$ - chlorophyll $a$, TN total nitrogen, TP - total phosphorus, ALK - alkalinity, COND - conductivity, SES - total seston, n.d. - no data

Data for 1967-1998 according to Zachwieja (1973), Spodniewska and Hilbricht-Ilkowska (1973), Węgleńska et al. (1979), Karpiński (1994), Zdanowski et al. (1999)

Letter indexes (a, b, c, d, e, f) indicate statistically significant differences between each period marked by the same letters: for SDD $(\mathrm{n}=39): \mathrm{a}-\mathrm{P}=0.0001, \mathrm{~b}-\mathrm{P}=0.0008, \mathrm{c}-\mathrm{P} 0.0050, \mathrm{~d}-\mathrm{P}=0.0212$ and for Chl $-\mathrm{a}(\mathrm{n}=29): \mathrm{e}-\mathrm{P}=0.0054, \mathrm{f}-\mathrm{P}=0.0108$

noted in 1975-1984, following which the values were much lower.

\section{Phytoplankton growth patterns and dominance shifts}

Multi-year comparisons of seasonal phytoplankton growth focused on the two main periods of 2000-2004 with Charales domination and
$100 \%$ was noted in 2005-2008. The second sub-period was in 2009-2011 with lower biomass at a maximum of up to $16.1 \mathrm{mg} \mathrm{dm}^{-3}$, followed by the 2012 period with a decrease of up to $8.7 \mathrm{mg} \mathrm{dm}^{-3}$, and the last period in 2013-2014 with an increase of up to $15.3 \mathrm{mg} \mathrm{dm}^{-3}$. Comparing the overall multi-year changes in total biomass from 2000 to 2014, the differences were statistically significant (Kruskal-Wallis $\mathrm{H}$ test $(14 ; 104)=28.0378 ; \mathrm{P}=0.0141)$.
2005-2014 with phytoplankton domination. In the former, the total phytoplankton biomass ranged from 0.1 to $4.7 \mathrm{mg} \mathrm{dm}^{-3}\left(1.79 \mathrm{mg} \mathrm{dm}^{-3}\right.$, on average; Fig. 3). In the latter, the total biomass fluctuated within a wider range of 0.1 to $20.3 \mathrm{mg} \mathrm{dm}^{-3}$, and it was significantly higher (approximately three-fold, Mann-Whitney $\mathrm{U}$ test $=511$; $\mathrm{P}=0.00002)$ than in 2000-2004. The overall variation in biomass values was also higher in 2005-2014 (CV 92\%) than in 2000-2004 (CV 72\%). Furthermore, phytoplankton growth in the second period was characterized by four sub-periods with high amplitude changes. The first sub-period with maximum total biomass of approximately $20.0 \mathrm{mg} \mathrm{dm}^{-3}$ and a CV of approximately

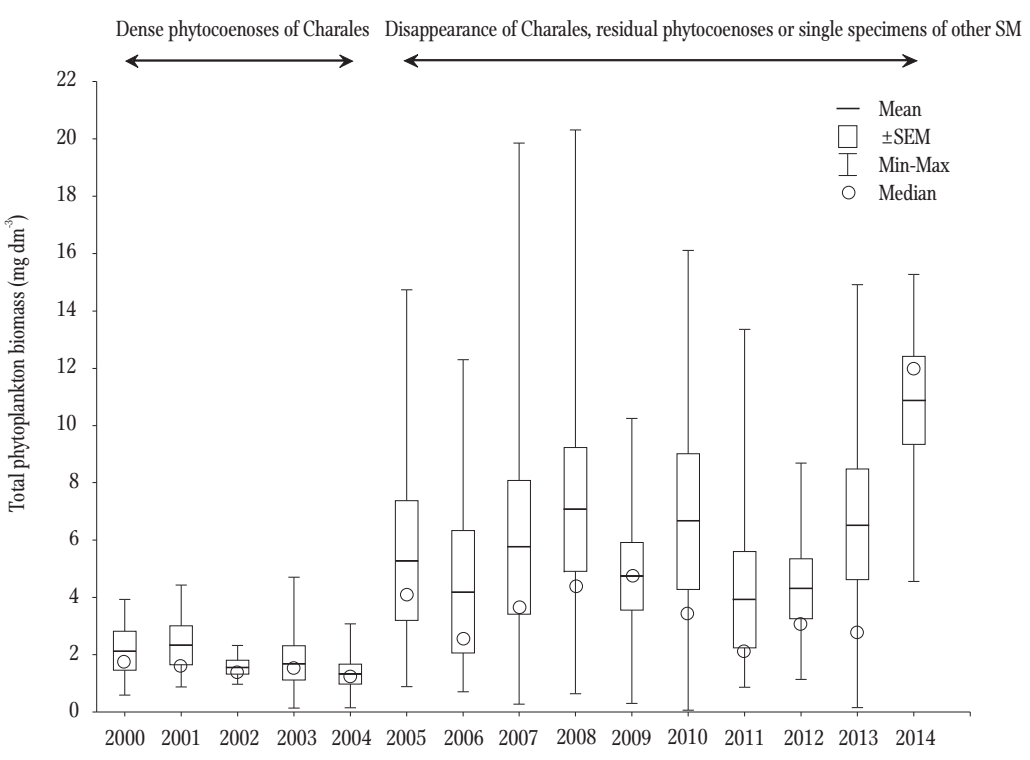

Figure 3. Total phytoplankton biomass in Lake Warniak in 2000-2014; SM - submerged macrophytes. 
Table 6

Long-term changes in summer phytoplankton biomass and structure (average and \% of total biomass in brackets) in Lake Warniak in 1967-2014

\begin{tabular}{lllll}
\hline \hline Periods & Total biomass & Cyanobacteria & Nannoplankton & Cy:Nan ratio \\
\hline \hline $1967-1974$ & $3.46^{\mathrm{a}}$ & $0.62(18 \%)$ & $2.39(69 \%)$ & 0.26 \\
$1975-1984$ & $14.83^{\mathrm{ab}}$ & $6.42^{\mathrm{e}}(43 \%)$ & $4.84(33 \%)$ & 1.33 \\
$1985-1994$ & $10.30^{\mathrm{c}}$ & $3.72(36 \%)$ & $5.46(53 \%)$ & 0.68 \\
$1995-1998$ & 6.53 & $1.36(21 \%)$ & $0.78(12 \%)$ & 1.74 \\
$2000-2004$ & $2.57^{\mathrm{bcd}}$ & $0.18^{\mathrm{e}}(7 \%)$ & $1.29(50 \%)$ & 0.14 \\
$2005-2014$ & $9.90^{\mathrm{d}}$ & $3.90(39 \%)$ & $1.19(12 \%)$ & 3.28 \\
\hline \hline
\end{tabular}

Cy:Nan ratio - a ratio of cyanobacteria biomass to nannoplankton biomass

Letter indexes ( $a, b, c, d, e)$ indicate statistically significant differences between each period marked by the same letters for total biomass $(n=42): a-P=0.036, b-P=0.019, c-P=0.040, d-P=0.046$ and for cyanobacteria biomass $(n=42): e-P=0.016$

Data according to Spodniewska and Hilbricht-Ilkowska 1973, Spodniewska 1975, Węgleńska et al. 1979, Zdanowski et al. 1999, current data

Long-term comparisons of summer phytoplankton biomass confirmed the high amplitude of changes from period to period (Table 6). In the summers of 1967-1974, the phytoplankton biomass was approximately $3.5 \mathrm{mg} \mathrm{dm}^{-3}$, on average. Summer biomass increased significantly to approximately $14.8 \mathrm{mg}$ $\mathrm{dm}^{-3}$ in 1975-1984, and then it decreased to approximately $10.3 \mathrm{mg} \mathrm{dm}^{-3}$ in 1985-1994. This downward trend continued in the subsequent two periods, but an increasing trend was noted later. In 2000-2004, the average biomass was relatively low and was most similar to that in 1967-1974, and it was significantly different from that in 1975-1994. After 2004, summer biomass was comparable with data for 1985-1994, but it was significantly higher than in 2000-2004.

Changes in phytoplankton structure were also very dynamic. The overall taxonomic pattern was similar, and the assemblages were formed by taxa belonging to the following eight phyla in each of the years studied: Cyanobacteria; Bacillariophyta; Charophyta (planktonic microorganisms, primarily desmids and conjugating green algae previously belonging to Chlorophyta); Chlorophyta; Cryptophyta; Euglenozoa (previously Euglenophyta); Miozoa (previously Dinophyta); Ochrophyta (including primarily Chrysophyceae, while Synurophyceae and Eustigmatophyceae were noted rarely). Distinct differences were noted in the domination structure of the phytoplankton assemblages.
In 2000-2004, which was the period dominated by Charales, cryptophytes were the dominant phytoplankton group, and they formed from $40 \%$ (2000) to $72 \%(2001,2004)$ of the average seasonal total biomass (ASTB) (Fig. 4). The main representatives were the nannoplanktonic species Cryptomonas curvata Ehrenberg, C. marssonii Skuja, Plagioselmis nannoplanctica (H.Skuja) G.Novarino, I.A.N.Lucas \& S.Morrall, and Rhodomonas lens Pascher \& Ruttner (Table 7). Chlorophytes (from 6\% in 2004 to 32\% in 2003), represented primarily by Chlorella vulgaris Beyerinck and Oocystis marssonii Lemmermann, were also abundant and included nannoplankton-sized species. Cyanobacteria formed up to 15\%, diatoms $-13 \%$, and dinophytes $-12 \%$ of ASTB with Microcystis aeruginosa (Kützing) Kützing, Ulnaria acus (Kützing) Aboal, and Peridiniopsis sp. as the main representatives, respectively. The share of the rest of taxonomic groups did not reach $10 \%$.

In 2005-2008, the period during which Charales disappeared, cyanobacteria were exclusively dominant in phytoplankton assemblages at approximately $65 \%$ of ASTB. The colony-forming chroococcalean picoplanktonic Aphanocapsa incerta (Lemmermann) G.Cronberg \& Komárek was then the dominant species with a share of approximately 60\%. Chrysophytes (belonging to Ochrophyta), primarily Dinobryon divergens O.E.Imhof and Uroglenopsis americana (G.N.Calkins) Lemmermann, reached a share of up to $18 \%$ in 2008 , but, on average, they 


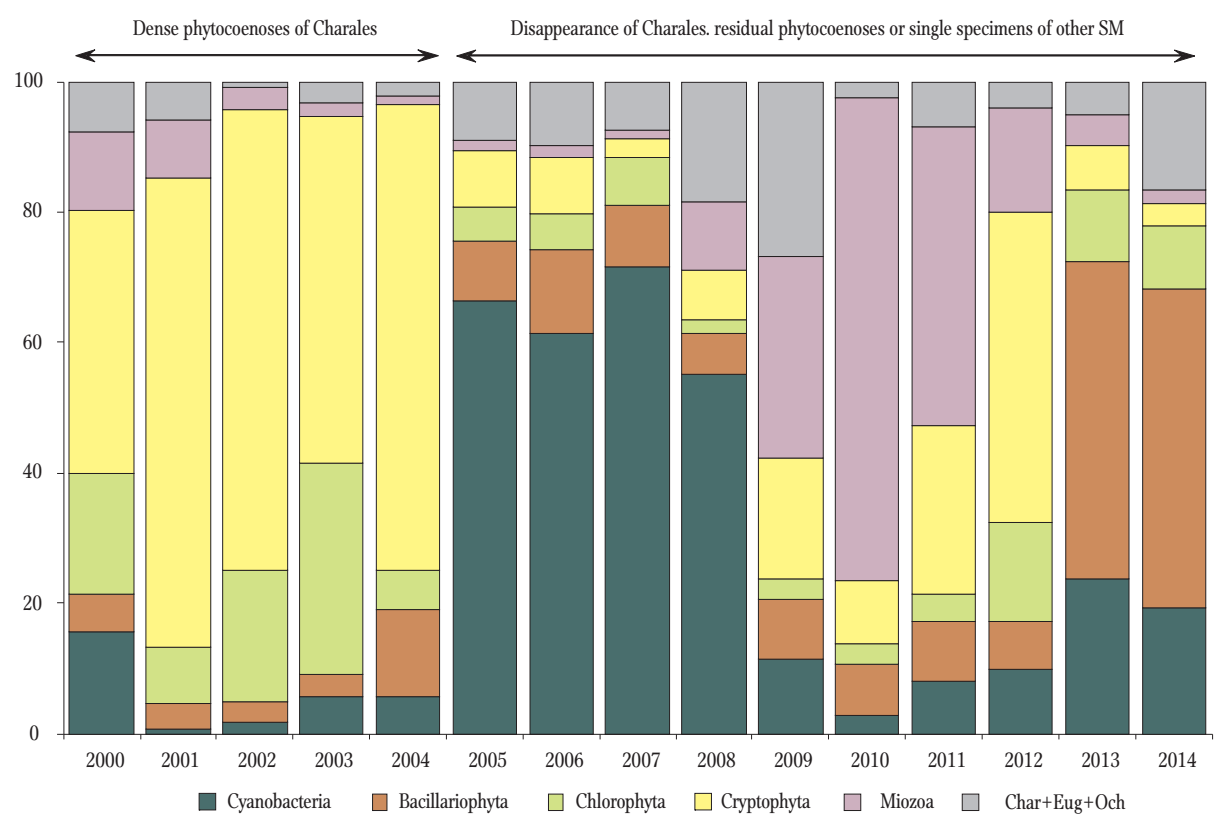

Figure 4. Average structure of phytoplankton assemblages in Lake Warniak in 2000-2014; Char+Eug+Ochr - planktonic Charophyta, Euglenozoa, and Ochrophyta, SM - submerged macrophytes.

were only $8 \%$ (Table 7). Diatoms, primarily U. acus and Fragilaria crotonensis Kitton, accounted for up to $13 \%$ in 2006 (on average 6\%). Dinoflagellates, with dominant the Peridinium willei Huitfeldt-Kaas and Ceratium hirundinella (O.F.Müller) Dujardin, contributed the highest share in 2008 (10\%), but the average was lower in 2005-2008. While in 2009-2011 (31-74\%, on average 53\%) they prevailed in the assemblages. Next, chrysophytes (with a maximum of $26 \%$ in 2009$)$ and cryptophytes (18\% in $2009,26 \%$ in 2011) also had a relatively high share. These two phyla were represented primarily by Mallomonas lychenensis W.Conrad, M. elegans Lemmermann, and C. curvata, and $P$. nannoplanctica, respectively.

In 2012, when the lowest mean and maximum total biomass values for the second period (2005-2014) were noted, the structure of phytoplankton assemblages was most similar to that in 2000. Thus, there was a short-term shift back toward the taxonomic structure observed during the clear-water state. Nannoplanktonic cryptophytes of the genera Cryptomonas, Plagioselmis, and Rhodomonas once again dominated, but this time dinoflagellates (P. willei) and chlorophytes (Oocystis lacustris Chodat) were also relatively abundant. The phytoplankton structure shifted again over 2013-2014 toward diatom domination (49\%). Similarly to the sub-period of 2005-2008, U. acus and F. crotonensis were the most abundant among Bacillarophyceae. The relatively high biomass of small-sized Pantocsekiella comensis (Grunow) K.T.Kiss \& E.Ács and Asterionella formosa Hassall was also noted. The share of cyanobacteria, represented primarily by A. incerta and Aphanothece sp., was relatively high at approximately $22 \%$.

Generally, the phytoplankton changes after 2004 deviated from the assemblages of a clear-water state with the domination of Charales in total biomass and in that of particular groups (Fig. 5). The highest positive amplitude of deviations from the mean biomass in 2000-2004 was recorded in 2014 because of the domination of diatoms. High deviations were also recorded in 2007-2008 and in 2010 primarily because of the occurrence of cyanobacteria and dinoflagellates, and in 2013 because of the high share of diatoms. Cryptophytes dominated in 2000-2004, but their biomass usually deviated negatively, except in 2012.

Comparisons of long-term summer phytoplankton structure also confirmed considerable changes from 
Table 7

Main representatives in phytoplankton assemblages throughout the growth seasons in 2000-2014, based on relative biomass (\% of average seasonal total biomass)

\begin{tabular}{|c|c|c|c|c|c|}
\hline \multirow[b]{2}{*}{ Species } & \multicolumn{5}{|c|}{ Growth season } \\
\hline & $2000-2004$ & $2005-2008$ & 2009-2011 & 2012 & 2013-2014 \\
\hline \multicolumn{6}{|l|}{ CYANOBACTERIA } \\
\hline Aphanocapsa incerta & 1.4 & 60.0 & 2.1 & 0.6 & 9.0 \\
\hline Aphanothece sp. & 0 & 0 & 2.5 & 0.6 & 6.4 \\
\hline Chroococcus minutus & $<0.1$ & $<0.1$ & $<0.1$ & 7.7 & 0.2 \\
\hline Merismopedia tenuissima & $<0.1$ & 2.5 & $<0.1$ & 0 & 0.1 \\
\hline Microcystis aeruginosa & 3.3 & 2.2 & 1.0 & 0.1 & 2.5 \\
\hline Woronichinia compacta & $<0.1$ & $<0.1$ & 0.2 & $<0.1$ & 1.1 \\
\hline \multicolumn{6}{|l|}{ BACILLARIOPHYTA } \\
\hline Acantoceras zacchariasii & 0 & 0.4 & 1.2 & 0 & 1.0 \\
\hline Asterionella formosa & $<0.1$ & 0.7 & 0.9 & $<0.1$ & 2.1 \\
\hline Fragilaria construens & 0.6 & 0.8 & 1.2 & 2.3 & 2.2 \\
\hline Fragilaria crotonensis & 0.3 & 1.3 & 0.4 & 0.2 & 10.2 \\
\hline Iconella linearis & 0 & 0 & 0.1 & 0.4 & 1.3 \\
\hline Pantocsekiella comensis & $<0.1$ & 0.1 & 0.6 & 0.8 & 8.6 \\
\hline Ulnaria acus & 2.2 & 2.4 & 2.1 & 1.7 & 19.5 \\
\hline Urosolenia longiseta & 0 & 0 & $<0.1$ & 0 & 1.4 \\
\hline \multicolumn{6}{|l|}{ CHLOROPHYTA } \\
\hline Chlorella vulgaris & 8.0 & $<0.1$ & 0.1 & 0.9 & $<0.1$ \\
\hline Coenococcus planctonicus & 0.6 & 0.8 & 0.4 & 0.8 & 3.1 \\
\hline Oocystis lacustris & $<0.1$ & 0 & 0.1 & 7.9 & 0.2 \\
\hline Oocystis marssonii & 3.5 & 0.2 & 0.1 & 0.1 & 0.2 \\
\hline Pseudopediastrum boryanum & 1.0 & 0.2 & 0.1 & 0.3 & 0.5 \\
\hline \multicolumn{6}{|l|}{$\mathrm{MIOZOA}$} \\
\hline Ceratium hirundinella & $<0.1$ & 1.1 & 4.1 & 2.0 & 1.7 \\
\hline Parvodinium inconspicuum & 1.0 & $<0.1$ & 0 & $<0.1$ & $<0.1$ \\
\hline Peridiniopsis sp. & 5.4 & 0.1 & 0.1 & 0.5 & 0.1 \\
\hline Peridinium volzii & 0 & 0 & 3.1 & 0.7 & 0.2 \\
\hline Peridinium willei & $<0.1$ & 3.2 & 45.8 & 11.7 & 1.1 \\
\hline \multicolumn{6}{|l|}{ EUGLENOZOA } \\
\hline Euglena viridis & 1.0 & 0.1 & $<0.1$ & $<0.1$ & 0.2 \\
\hline Trachelomonas volvocina & 1.0 & 0.3 & 0.7 & 0.3 & 0.1 \\
\hline \multicolumn{6}{|l|}{ CRYPTOPHYTA } \\
\hline Plagioselmis nannoplanctica & 6.1 & 2.1 & 4.2 & 6.1 & 1.9 \\
\hline Cryptomonas erosa & 0.5 & 0.4 & 3.3 & 12.4 & 0.7 \\
\hline Cryptomonas marssonii & 5.8 & 0.5 & 2.6 & 2.1 & 0.6 \\
\hline Cryptomonas curvata & 45.0 & 2.6 & 6.5 & 24.9 & 1.5 \\
\hline Rhodomonas lens & 2.7 & 0.1 & $<0.1$ & 2.0 & 0.1 \\
\hline \multicolumn{6}{|l|}{ OCHROPHYTA } \\
\hline Chromulina elegans & 1.1 & 1.1 & $<0.1$ & 0 & $<0.1$ \\
\hline Dinobryon bavaricum & 0 & 0 & $<0.1$ & 0 & 2.1 \\
\hline Dinobryon crenulatum & 0.1 & 0.1 & 0.1 & 1.4 & 0.1 \\
\hline Dinobryon cylindricum & 0 & 0 & 0 & 0 & 2.0 \\
\hline Dinobryon divergens & 0.1 & 4.4 & 1.5 & 0.2 & 2.4 \\
\hline Mallomonas lychenesis & 0 & 0 & 3.5 & 0.1 & $<0.1$ \\
\hline Mallomonas elegans & 0 & 0.8 & 3.5 & 0.1 & 0.3 \\
\hline
\end{tabular}


Table 7, cont.

\begin{tabular}{|c|c|c|c|c|c|}
\hline \multirow[b]{2}{*}{ Species } & \multicolumn{5}{|l|}{ Growth season } \\
\hline & $2000-2004$ & $2005-2008$ & 2009-2011 & 2012 & 2013-2014 \\
\hline Uroglenopsis americana & 0 & 1.5 & 0 & 0 & 0 \\
\hline \multirow{2}{*}{ Functional groups ${ }^{1}$} & \multirow{2}{*}{$\mathrm{Y}, \mathrm{X} 1, \mathrm{X} 2, \mathrm{~L}_{0}$} & $\mathrm{~K}$ & $\mathrm{~L}_{0}, \mathrm{Y}$ & $\mathrm{Y}, \mathrm{L}_{0}, \mathrm{~F}, \mathrm{X} 2$ & $\mathrm{D}, \mathrm{K}, \mathrm{P}, \mathrm{A}$ \\
\hline & & \multicolumn{4}{|c|}{$\mathrm{K}, \mathrm{L}_{0}, \mathrm{Y}, \mathrm{D}$} \\
\hline \multirow{2}{*}{ Eco-sensitivity factor ${ }^{2}$} & \multirow{2}{*}{$0.33(0.19-0.69)$} & 3.85 & 0.10 & 0.23 & 1.36 \\
\hline & & \multicolumn{4}{|c|}{$1.59(0.03-3.85)$} \\
\hline
\end{tabular}

${ }^{1}$ Functional groups based on $\geq 5 \%$ relative biomass of representatives according to Reynolds et al. (2002) and Padisák et al. (2009); habitat characteristics: A - clear, deep, often well-mixed, base poor, D - shallow turbid, F - clear epilimnia, deeply mixed meso-eutrophic, $\mathrm{K}$ - shallow, nutrient-rich, $\mathrm{P}$ - shallow eutrophic epilimnia, $\mathrm{L}_{\mathrm{O}}$ - summer epilimina, deep and shallow, oligo-, meso- and eutrophic, X1 - shallow, eu-hypertrophic, X2 - shallow, meso-eutrophic and Y - small enriched water bodies ${ }^{2}$ Eco-sensitivity factor as a biomass ratio of tolerant to sensitive taxa according to Napiórkowska-Krzebietke et al. (2017); an average summer and range in brackets

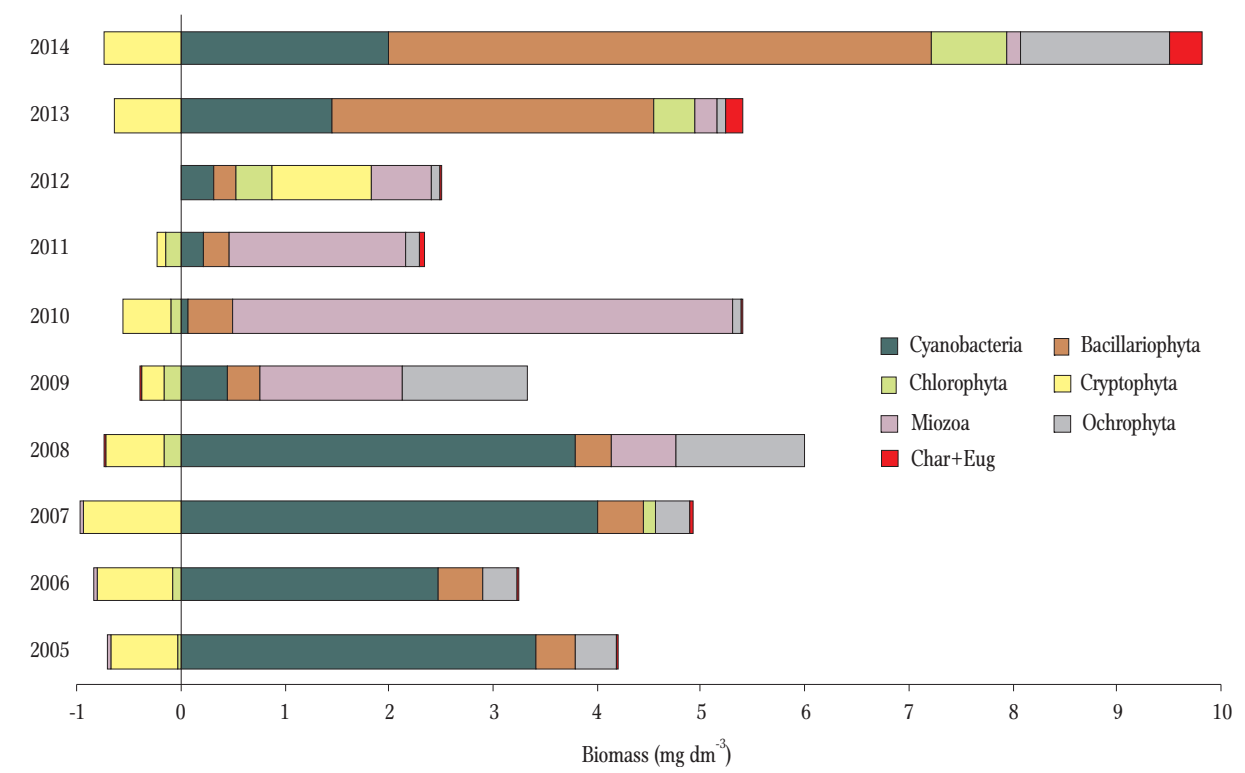

Figure 5. Deviations in the phytoplankton components from a clear-water state in 2000-2004 in Lake Warniak based on an average seasonal biomass; Char+Eug - planktonic Charophyta and Euglenozoa.

period to period (Table 6). The highest share in the total phytoplankton biomass was either of cyanobacteria or nannoplankton-sized algae. In 1967-1974, nannoplankton (69\%) dominated the phytoplankton, but in 1975-1984, cyanobacteria constituted 43\% of the total phytoplankton biomass. In 1985-1994, nannoplankton again attained the highest phytoplankton biomass at $53 \%$, but in the next period it was only $12 \%$. The same tendency in changes was recorded in the next two periods; in 2000-2004 nannoplankton prevailed, whereas in 2005-2014 cyanobacteria prevailed. These relationships were illustrated by calculating the cyanobacteria-to-nannoplankton biomass ratio, which ranged between 0.14 and 3.28 (Table 6).

The taxonomic structure included 339 taxa (only this which contributed to the total phytoplankton biomass), belonging to 161 genera, and eight phyla were recorded in the phytoplankton. Multi-year comparisons of species richness indicated changes in the total number of taxa from 77 to 124 in 2000-2004 and from 125 to 155 in 2005-2014, at averages of 

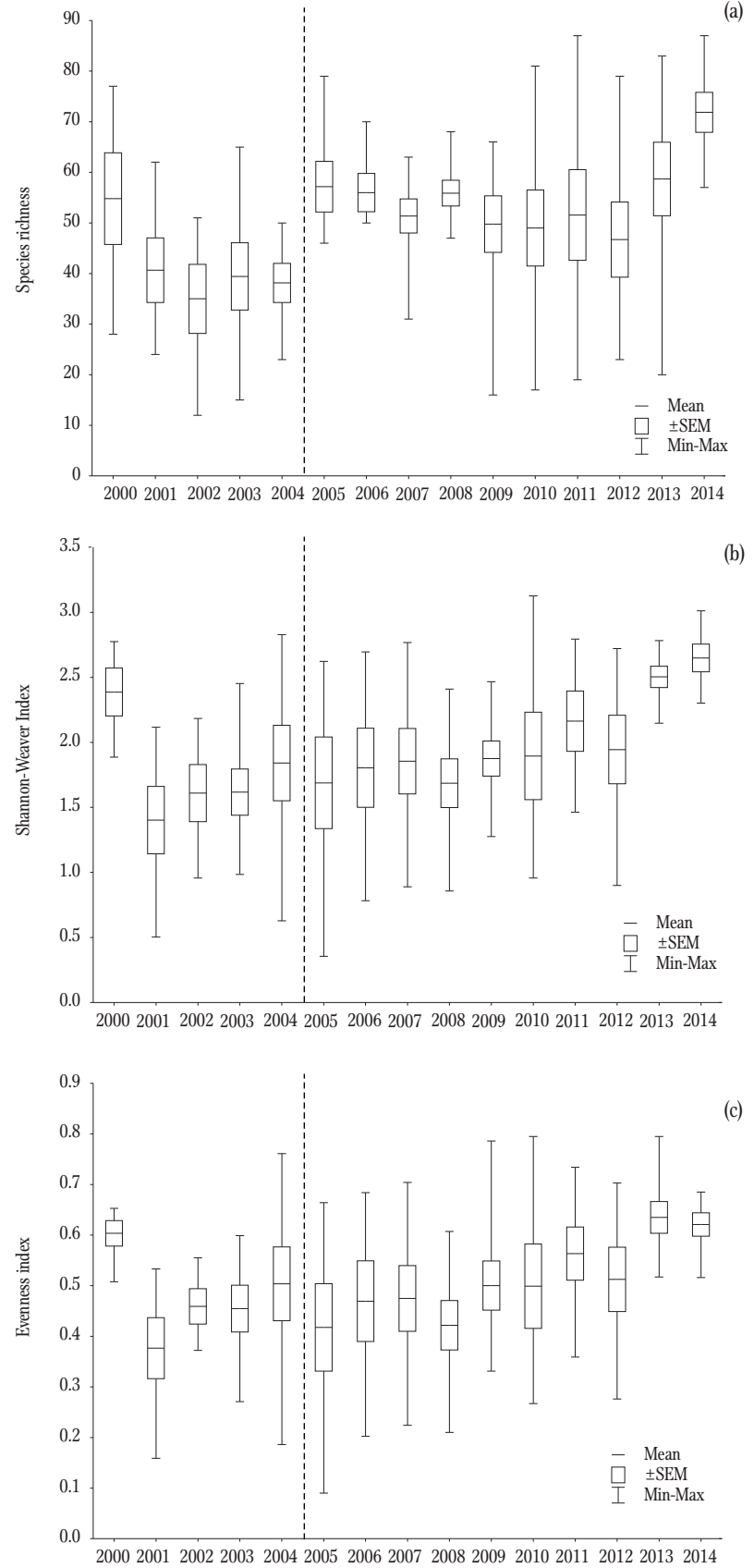

Figure 6. Species richness (a) and diversity indices (b, c) in the phytoplankton assemblages in Lake Warniak throughout the growth seasons in 2000-2014; dashed vertical line separates two periods: 2000-2004 and 2005-2014.

103 and 136 taxa, respectively. Seasonally, the number of species ranged from 12 to 77 and from 16 to 87 in the two periods, respectively (Fig. 6a). Diversity indices indicated slightly higher biodiversity in 2005-2014 than in 2000-2004, i.e. S-WI $=2.03$ and $\mathrm{E}=0.52, \mathrm{~S}-\mathrm{WI}=1.75$ and $\mathrm{E}=0.48$ on average, respectively (Fig. 6b-6c). The hierarchical clustering of similarity-based taxonomic structures confirmed this distinct division (Fig. 7). The first group with highly similar (77\%) phytoplankton assemblages was from 2002 and 2004, and it formed the "center of the aggregation" in a coherent group, which also contained samples from 2003 and 2000. Moreover, phytoplankton similar to this group developed in 2001 and 2012, when the samples created a new sub-group with a mutual similarity of $64 \%$. In these years, cryptophytes were the most abundant in the phytoplankton. The second group, with the highest similarity of $83 \%$ between 2006 and 2007 contained samples from 2005-2008 period, which means that second coherent group of samples were dominated by cyanobacteria. The most similar to this group was the phytoplankton structure in 2013-2014 (31\%) when mainly diatoms dominated, but there was also a high share of cyanobacteria. Another separate group that was relatively highly similar (over 50\%) was created by converging samples from 2009-2011. Furthermore, this third group with a high share of dinophytes was more similar to the first group (34\%) than to the second group (18\%).

\section{Modelling seasonal changes in phytoplankton growth patterns, structures, and biodiversity}

During the 2000-2004 period of Charales domination, seasonal phytoplankton growth patterns revealed a clear tendency of the occurrence of two total biomass peaks; the first was in spring (March) and the second in summer (August), with the minimum usually observed in May (Fig. 8). Both biomass peaks were comparably relatively low and formed primarily by small-sized cryptophytes in early spring and by the co-domination of cryptophytes and chlorophytes in August (Fig. 9a). A distinct presence of diatoms and cyanobacteria was also observed in the spring and summer phytoplankton assemblages, respectively. Generally, phytoplankton dominated by cryptophytes developed abundantly throughout the growth season in the first study period. 


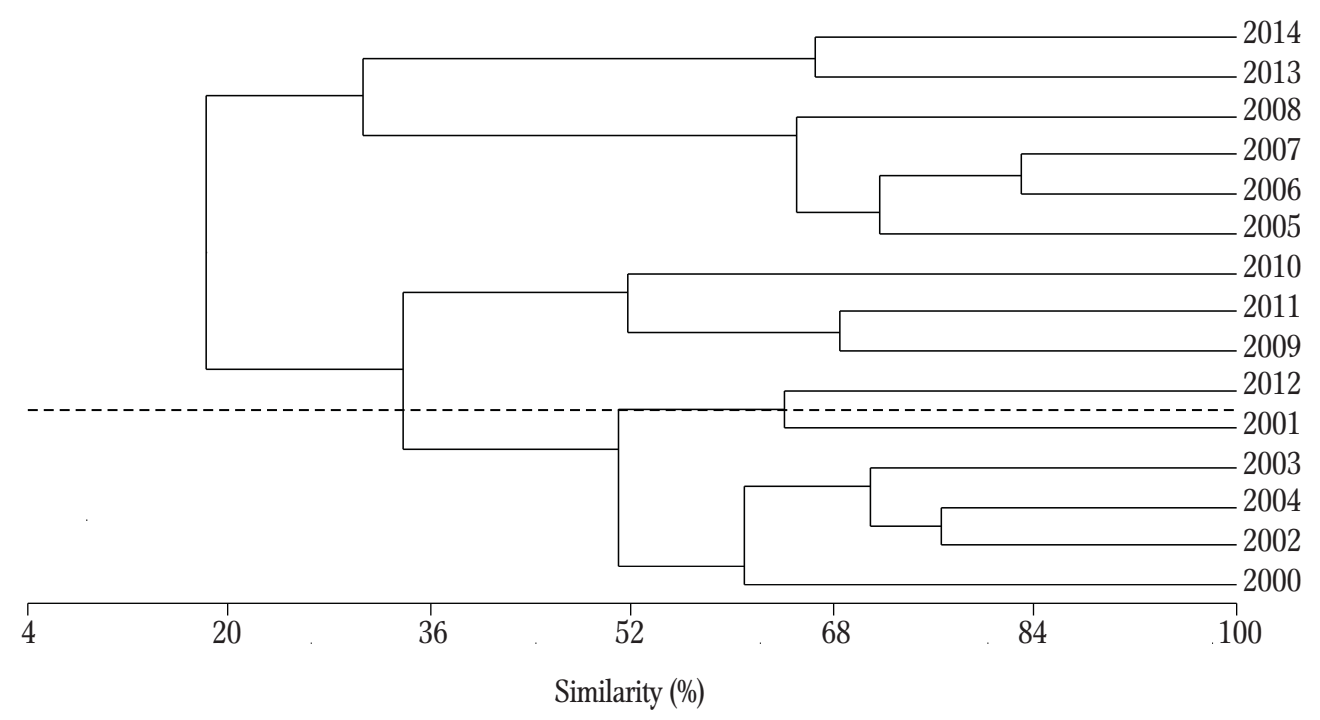

Figure 7. Hierarchical cluster analysis based on UPGMA (Unweighted Pair Group Method with Arithmetic Mean) and percent similarity matrix of phytoplankton taxa in Lake Warniak throughout the growth seasons in 2000-2014; dashed horizontal line separates two periods: 2000-2004 and 2005-2014.

In the next period (2005-2014, after the disappearance of Charales), the general phytoplankton growth pattern exhibited only one peak of total biomass that usually occurred in July (Fig. 8). However, high biomass values were also sporadically recorded in June and September. The spring maximum and the typical minimum in May, which were observed during the previous period, were suppressed. Furthermore, the summer biomass maximum was also postponed. From June to September, cyanobacteria dominated phytoplankton assemblages with an average relative biomass of $40 \%$ (Fig. 9b), and the co-dominant groups were Miozoa (22\%) and Bacillariophyta (16\%). In spring and fall, Bacillariophyta, Cryptophyta, and Ochrophyta were the main structural components of the phytoplankton assemblages.

In both of the analysed periods, the phytoplankton assemblage species richness (SR) trends were similar (Fig. 10a). Generally, the highest values were recorded in summer (July, August, and September). The values of SR were usually higher in 2005-2014 than in 2000-2004 throughout the growth seasons. Biodiversity indices (Shannon-Weaver index and evenness) were more differentiated; higher values were recorded in spring and late fall, whereas lower values were recorded in

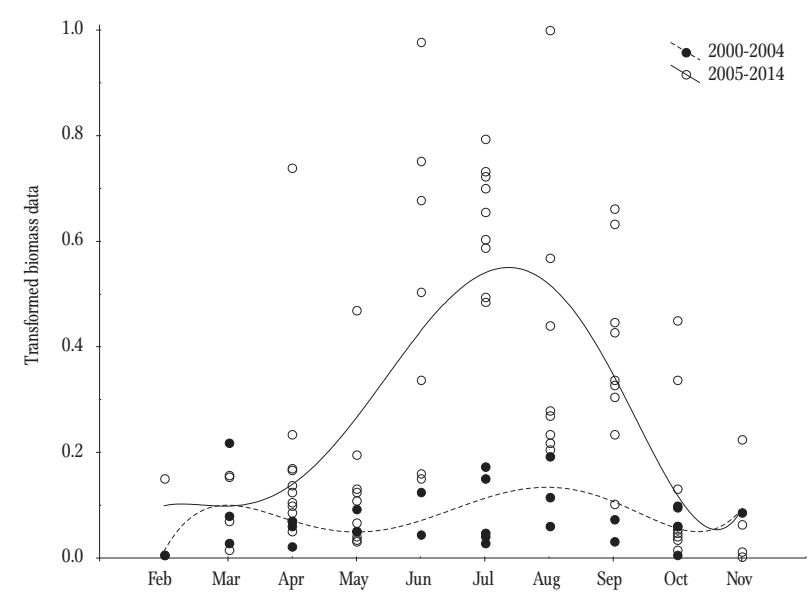

Figure 8. Seasonal phytoplankton growth pattern based on the transformed total biomass in Lake Warniak in 2000-2004 and 2005-2014.

summer during 2005-2014 than in 2000-2004 (Fig. 10b-10c).

Models of seasonal phytoplankton growth in previous years were created based on published historical data (Spodniewska and Hilbricht-Ilkowska 1973, Spodniewska 1975, Węgleńska et al. 1979). In the late 1960s, when primarily common carp was experimentally introduced into Lake Warniak, the summer maximum biomass usually occurred in August, and, exceptionally, once in July (Fig. 11a). The second biomass peak, which was lower than the first, 

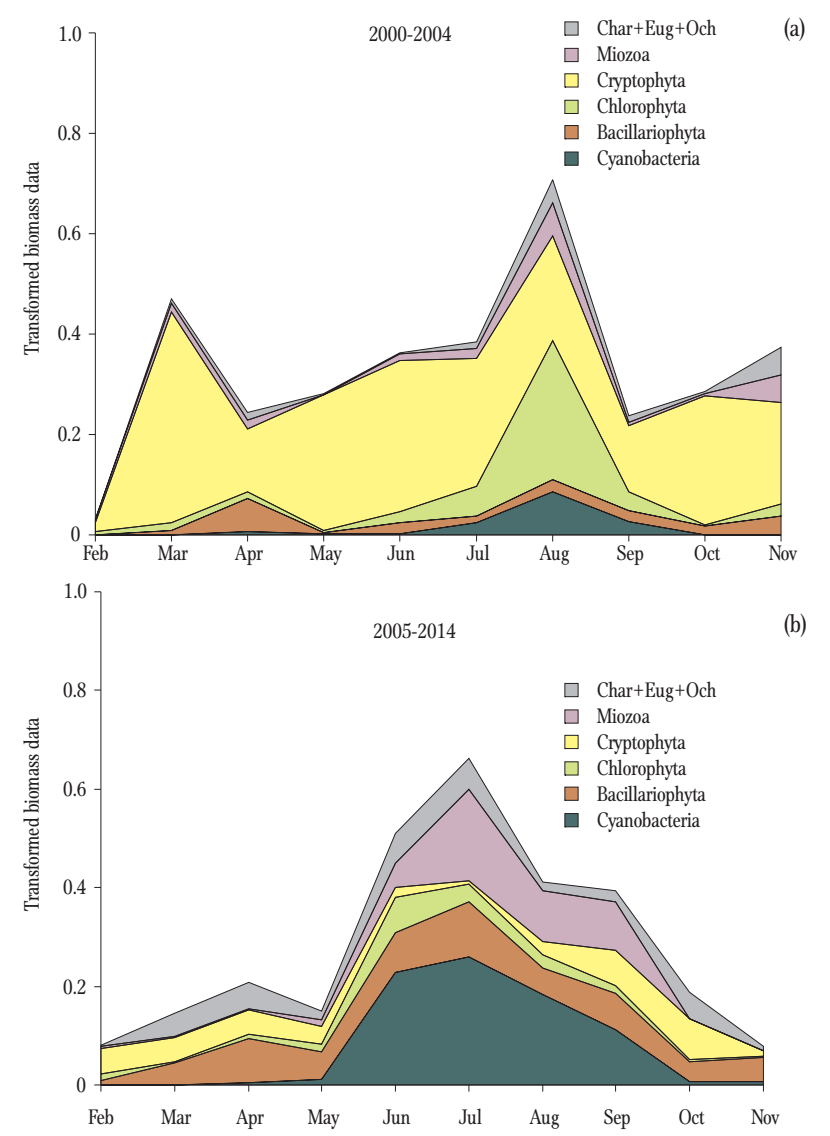

Figure 9. Models of a seasonal phytoplankton structure in Lake Warniak in 2000-2004 (a) and 2005-2014 (b); Char+Eug+Ochr - planktonic Charophyta, Euglenozoa, and Ochrophyta.

was in June (1967) and May (1969). In 1968, the biomass peaks in May and August were similar, but lower than those in 1967 and 1969. The early 1970s period of grass carp introduction was characterized by one phytoplankton biomass maximum in August (1973, 1974), but there was a tendency for a second maximum to form in early spring, or there were two maximums with one in May/June and the second in October $(1970,1971)$ (Fig. 11b). Compared with the current data, the changes in seasonal phytoplankton growth in 2000-2004 (pike and wels catfish stocking) were the most similar to 1968 (Fig. 11c). In the next two periods with the stocking of pike and other fish species (2005-2010) or only pike (2011-2014), the seasonal phytoplankton growth models were similar with a maximum occurring in July and two other, but lower, biomass peaks in April and
September. This tendency was not recorded in previous years.

\section{Phytoplankton response to fish-induced environmental changes}

The phytoplankton response to fish-induced environmental changes was primarily a result of experimental introductions of specific fish species into Lake Warniak beginning from the late 1960s (Table 2). In 1967-1969, the benthophagous common carp was first introduced into the lake. In 1970-1984, introductions were primarily of herbivorous grass carp, but there were also high stocking rates of common carp. In this period, seston-feeding carps, namely silver carp and bighead carp, were also introduced into the lake; however, in the 1970s stocking with these species was only occasional whereas in the $1980 \mathrm{~s}$ it was as high as $52.1 \mathrm{~kg} \mathrm{ha}^{-1}$. Their biomass peaked in 1993. The next years included some irregular stocking, primarily with common carp and pike. Intense exploitation in 1995 and 1997 and winter fish kills in 1985 and 1987 influenced the ichthyofauna in the lake considerably. The next fish stocking was of predatory autochthonous fish (primarily pike) in 2000-2014 (Table 3). The key vectors shaping the phytoplankton response to fish-induced environmental changes were: (1) abiotic variables, mainly temperature, light, and nutrient enrichment; (2) competition and grazing, (3) nutrient-phytoplankton-zooplankton-macrophyte -fish interactions.

\section{Abiotic variables}

Considerable changes were recorded in trophic parameters SDD, TP, TN, and chlorophyll $a$. The values of partial components of the Trophic Level Index (TLI $_{\mathrm{SDD}}, \mathrm{TLI}_{\mathrm{TP}}, \mathrm{TLI}_{\mathrm{Chl}}, \mathrm{TLI}_{\mathrm{TN}}$ ) ranged between 4.2 and 5.8 in the 2000-2004 and 2005-2014 study periods (Table 8 ). Throughout the growth season, the mean TLI values were 4.9 and 5.1 in 2000-2004 and 2005-2014, respectively. The slight increase in the TLI value in the second period suggests changes in trophic conditions from meso-eutrophic to eutrophic. 

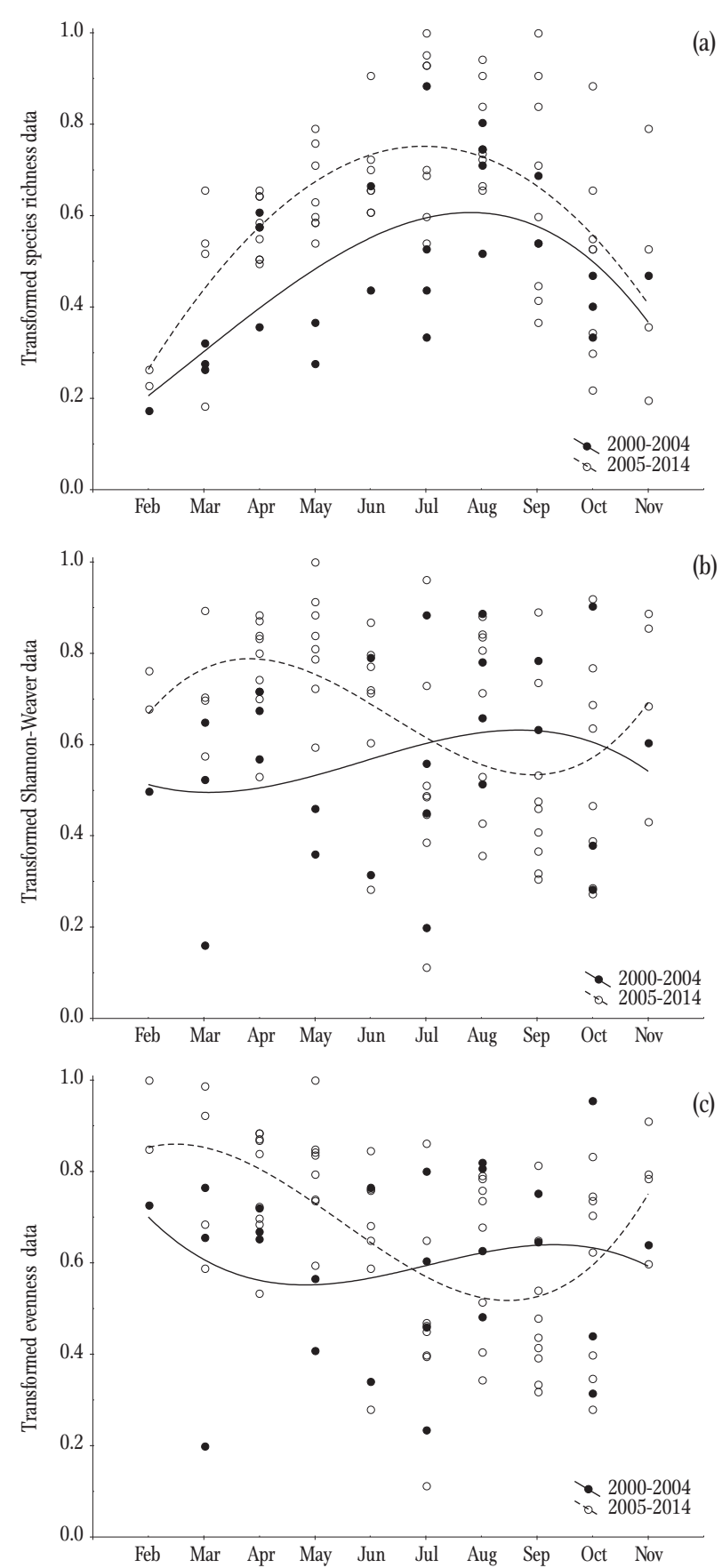

Figure 10. Models of seasonal changes in species richness (a) and diversity indices (b, c) in Lake Warniak in 2000-2004 and 2005-2014.

A similar tendency in trophic state change was recorded between the periods of 1967-1974 and 1975-1984 (calculated from historical data) when primarily herbivorous grass carp was introduced to the lake and contributed to the disappearance of submerged macrophytes.
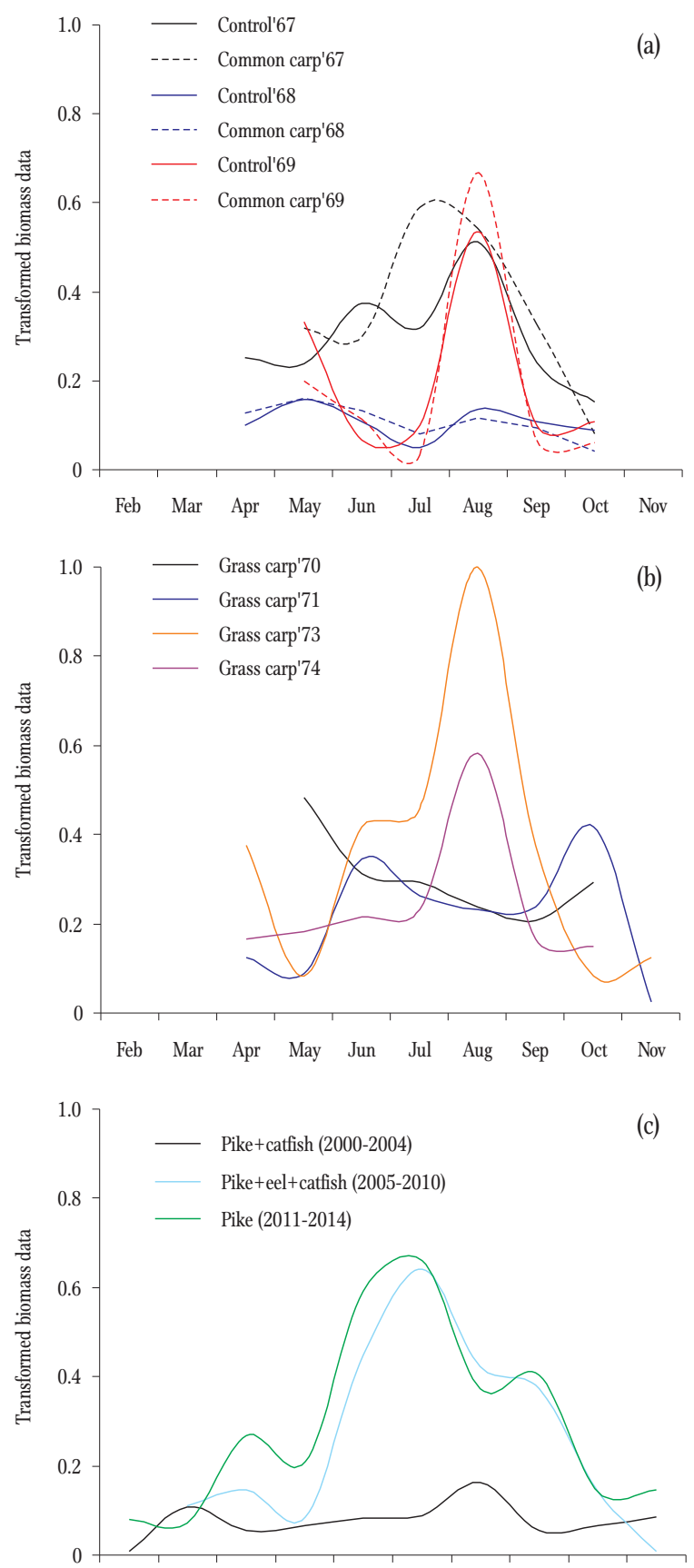

Feb Mar Apr May Jun Jul Aug Sep Oct Nov

Figure 11. Models of seasonal phytoplankton growth based on total biomass in periods of experimental fish introduction of common carp (a), grass carp (b), and stocking with pike, wels catfish and European eel (c), data according to Spodniewska and Hilbricht-Ilkowska (1973), Spodniewska (1975), Węgleńska et al. (1979), current data.

The functional traits of dominant taxa and some links between the main environmental drivers (mixing, light, nutrients) and phytoplankton, permitted identifying a clear change in the phytoplankton 
Table 8

Trophic state assessment according to Trophic Level Index (TLI) in Lake Warniak in 1967-2014 calculated from historical and current data

\begin{tabular}{|c|c|c|c|c|c|c|}
\hline Periods & $\mathrm{TLI}_{\mathrm{SDD}}$ & $\mathrm{TLI}_{\mathrm{Chl}}$ & $\mathrm{TLI}_{\mathrm{TN}}$ & $\mathrm{TLI}_{\mathrm{TP}}$ & $\mathrm{TLI}^{1}$ & Trophic state $^{2}$ \\
\hline $1967-1974$ & 4.1 & n.d. & n.d. & 5.4 & 4.7 & meso-eu \\
\hline $1975-1984$ & 5.1 & 5.8 & 6.0 & 6.1 & 5.7 & $\mathrm{eu}$ \\
\hline 1985-1994 & 4.8 & 5.4 & 6.0 & 5.8 & 5.5 & $\mathrm{eu}$ \\
\hline 1995-1998 & 4.2 & 4.6 & 5.9 & 5.6 & 5.1 & $\mathrm{eu}$ \\
\hline $2000-2004$ & 4.2 & 4.4 & 5.5 & 5.6 & 4.9 & meso-eu \\
\hline 2005-2014 & 4.5 & 4.7 & 5.5 & 5.8 & 5.1 & $\mathrm{eu}$ \\
\hline
\end{tabular}

${ }^{1}$ TLI - Trophic Level Index according to Burns et al. (1999) and partial indices based on Secchi disk depth (TLI SDD), chlorophyll $a\left(\mathrm{TLI}_{\mathrm{Chl}}\right)$, total nitrogen $\left(\mathrm{TLI}_{\mathrm{TN}}\right)$ and total phosphorus $\left(\mathrm{TLI}_{\mathrm{TP}}\right)$, n.d. - no data

${ }^{2}$ meso-eu - meso-eutrophic, eu - eutrophic according to Parparov et al. (2010)

Data for 1967-1988 according to Zdanowski et al. (1999)

domination structure. The functional group recorded most often, i.e., throughout the growth seasons in 2000-2004, was Y, the main representatives of which were Cryptomonas curvata, C. marssonii and C. erosa (Table 9). Group X2, which included the nannoplanktonic cryptophytes Plagioselmis nannoplanctica and Rhodomonas lens, was the second most common group in the phytoplankton assemblages. The groups X1, with Chlorella vulgaris, and $\mathrm{L}_{\mathrm{O}}$, with species of the genus Peridiniopsis, were the third and fourth most common groups. The species Ulnaria acus (group D), Oocystis marssonii (group F) and Microcystis aeruginosa (group M) were noted only sporadically in higher abundances.

After 2004, the phytoplankton assemblages were more differentiated. In spring 2005-2008, chrysophytes representing the functional groups $\mathrm{U}$ (Uroglenopsis americana) and E (Dinobryon sociale) with diatoms (group D - Ulnaria acus) were the most common (Table 9). In summer, the most abundantly developed cyanobacteria and dinoflagellates belonging to groups $\mathrm{K}$ (Aphanocapsa incerta) and $\mathrm{L}_{\mathrm{O}}$ (Peridinium willei). The nannoplanktonic Plagioselmis (X2) played an important role in the fall assemblages together with $D$. divergens (E), A. incerta $(\mathrm{K})$, and Asterionella formosa (C). In subsequent years (2009-2011), spring and fall phytoplankton assemblages were dominated by similar representatives of groups $\mathrm{Y}, \mathrm{X} 2$, and D as they were in 2000-2004 and 2005-2008. In summer, group $\mathrm{L}_{\mathrm{O}}$ (with the same representatives) was the most abundant and was accompanied by groups E (primarily Mallomonas elegans, M. lychenensis), Y (C. curvata), and $\mathrm{L}_{\mathrm{M}}$ (Ceratium hirundinella). The phytoplankton assemblages in 2012 were represented primarily by taxa belonging to groups $\mathrm{Y}, \mathrm{X} 2, \mathrm{E}, \mathrm{L}_{\mathrm{O}}$ (in spring), $\mathrm{F}, \mathrm{L}_{\mathrm{O}}, \mathrm{Y}, \mathrm{L}_{\mathrm{M}}$, MP (in summer), and Y and X2 (in fall). During the growth seasons in 2013-2014, the most important were diatoms representing groups MP (Iconella linearis), A (Pantocsekiella comensis), D (U. acus), and P (Fragilaria crotonensis, F. construens). An important contribution to the spring and fall assemblages also included taxa characteristic of groups X2, W2 (sporadically noted Trachelomonas volvocina), E, C, and $\mathrm{Y}$, whereas in summer K, F, and $\mathrm{L}_{\mathrm{M}}$ (with Microcystis aeruginosa and $C$. hirundinella) made an important contribution.

The general trends in the functional traits of phytoplankton that clearly characterize the phytoplankton response to environmental changes in both study periods were as follows (Table 7):

$$
\begin{gathered}
Y+X 2+X 1+L_{O}(2000-2004) \rightarrow K+L_{O}+Y+D \\
(2005-2014) .
\end{gathered}
$$

The phytoplankton assemblages then changed primarily from small-sized taxa:

\section{Cryptomonas/Plagioselmis + Rhodomonas/ Chlorella/Peridiniopsis (2000-2004)}

into colonial picoplanktonic cell size and large-sized taxa: 
Table 9

Main functional groups with typical representatives of phytoplankton in Lake Warniak

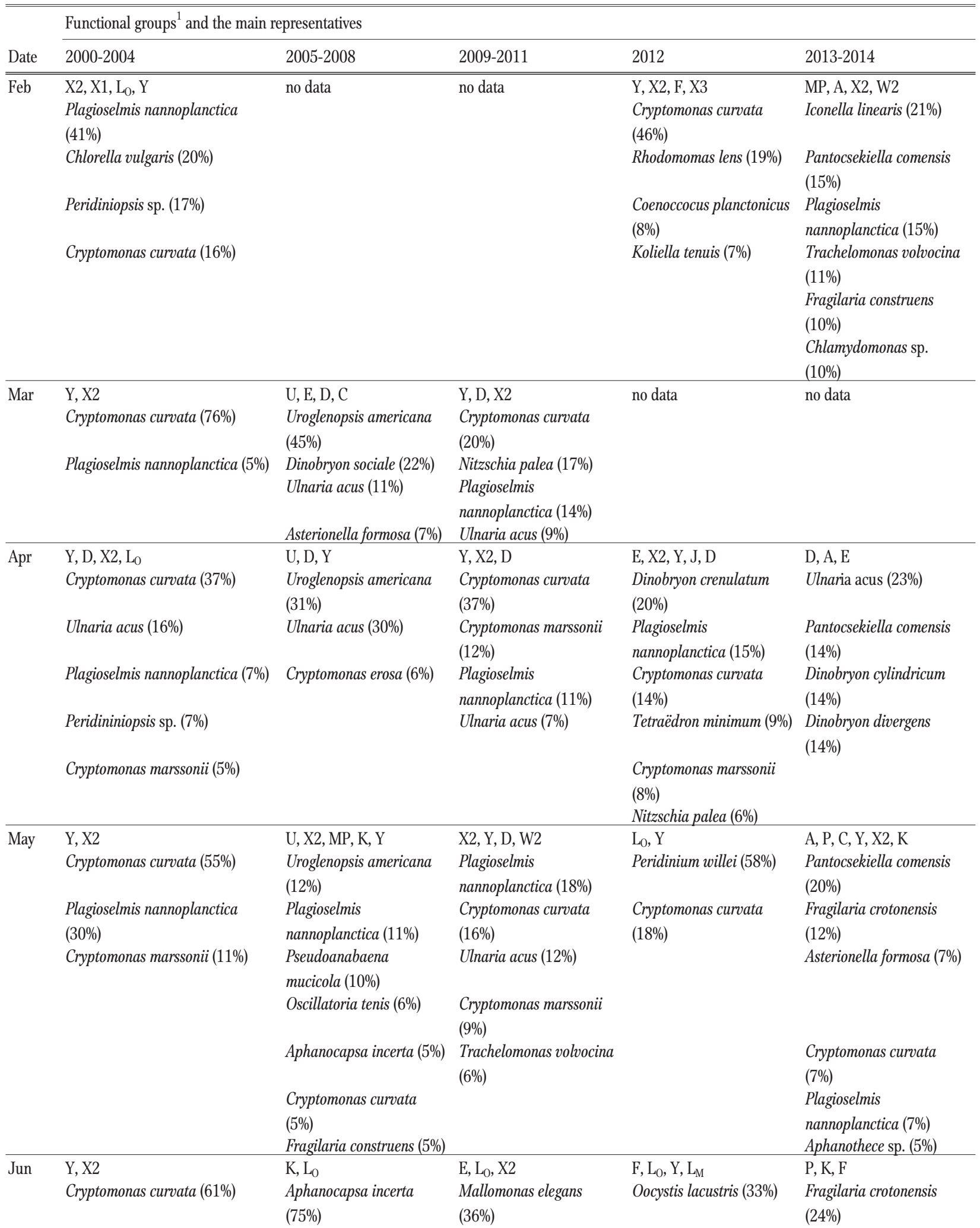


Table 9, cont.

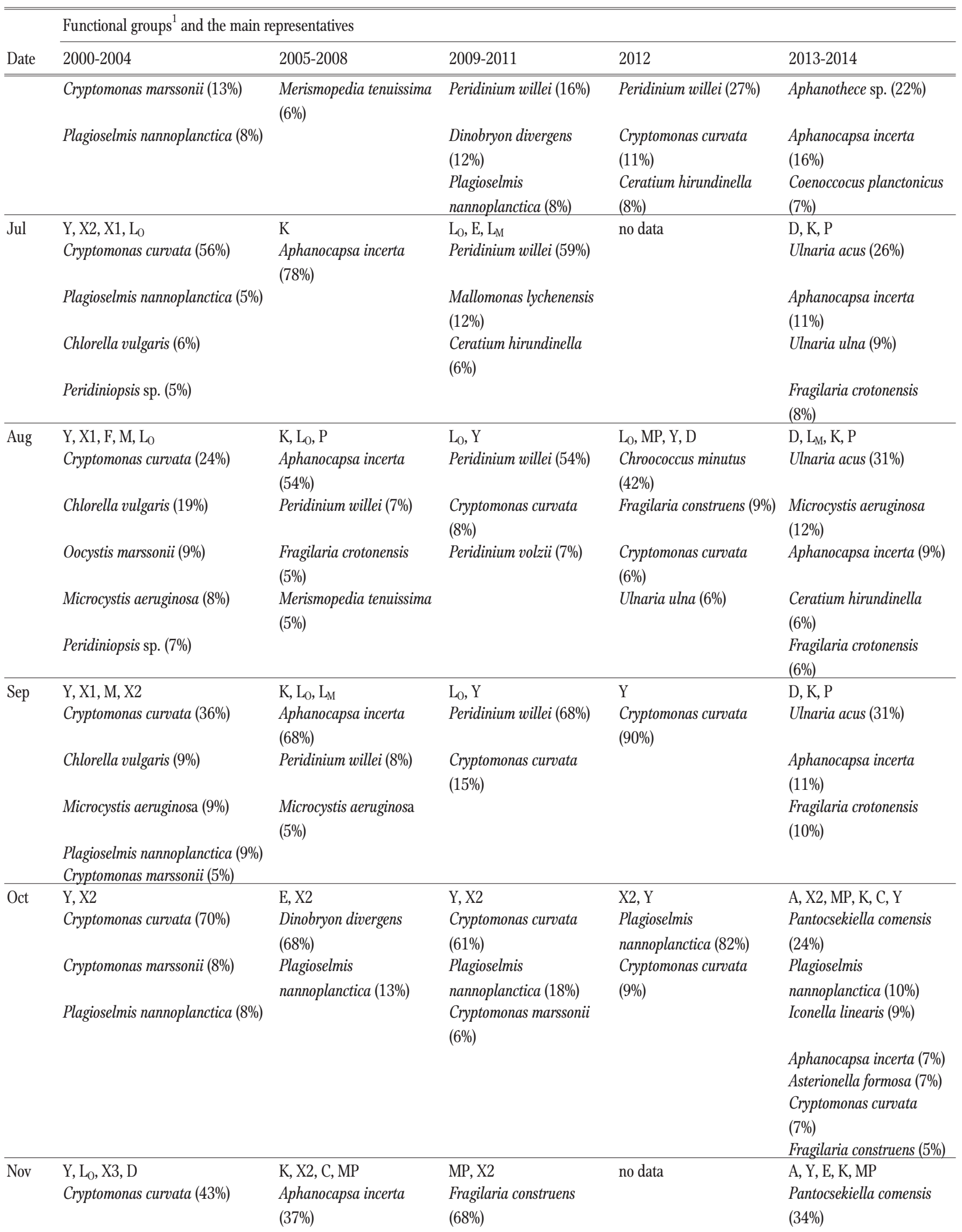


Table 9, cont.

\begin{tabular}{|c|c|c|c|c|}
\hline \multirow[b]{2}{*}{ Date } & \multicolumn{4}{|c|}{ Functional groups ${ }^{1}$ and the main representatives } \\
\hline & $2000-2004$ & $2005-2008$ & $2009-2011$ & 2013-2014 \\
\hline & Cryptomonas marssonii (11\%) & Plagioselmis & \multirow[t]{4}{*}{ Chlamydomonas sp. (8\%) } & Cryptomonas curvata \\
\hline & & nannoplanctica (17\%) & & $(7 \%)$ \\
\hline & Peridiniopsis sp. (15\%) & Asterionella formosa & & Dinobryon sociale $(6 \%)$ \\
\hline & & $(12 \%)$ & & \\
\hline & Chromulina sp. (10\%) & Fragilaria construens (9\%) & & Aphanocapsa incerta (5\%) \\
\hline & Ulnaria acus $(7 \%)$ & & & Iconella linearis $(5 \%)$ \\
\hline
\end{tabular}

${ }^{1}$ Functional groups based on $\geq 5 \%$ relative biomass of representatives according to Reynolds et al. (2002) and Padisák et al. (2009), habitat characteristics: A - clear, deep, often well-mixed, base poor, C - eutrophic small- and medium sized, D - shallow turbid, E - small, shallow, base poor or heterotrophic, F - clear epilimnia, deeply mixed meso-eutrophic, J - shallow, mixed, highly enriched, $\mathrm{K}$ - shallow, nutrient-rich, $\mathrm{P}$ - shallow, eutrophic epilimnia, $\mathrm{L}_{\mathrm{M}}$ - eu- to hypertrophic, small- to medium-sized, $\mathrm{L}_{\mathrm{O}}$ - summer epilimina, deep and shallow, oligo-, meso- and eutrophic, M - eu- to hypertrophic, small- to medium-sized, MP frequently stirred up, inorganically, turbid, shallow, U - oligo- and mesotrophic, exhausted nutrient resources in the upper layers but still available in the darker deep ones, W2 - meso-eutrophic, even temporary, shallow, X1 - shallow, eu-hypertrophic, X2 shallow, meso-eutrophic, X3 - shallow, well mixed oligotrophic and Y - small enriched water bodies

\section{Aphanocapsa/Peridinium/Cryptomonas/Ulnaria (2005-2014).}

However, the phytoplankton assemblages in the period after 2004 were more differentiated than in the years before 2004. Aphanocapsa-dominated phytoplankton (2005-2008) shifted forward to being dominated by Peridinium (2009-2011), then to being dominated by small-sized cryptophytes (2012), and finally to being dominated by diatoms with a high share of colonial picoplanktonic cyanobacteria (2013-2014). Thus, the shifts in functional traits were as follows:

$$
\begin{aligned}
& K(2005-2008) \rightarrow L_{O}+Y(2009-2011) \rightarrow Y+L_{O} \\
+ & F+X 2(2012) \rightarrow D+K+P+A(2013-2014) .
\end{aligned}
$$

The eco-sensitivity factor (E-SF), which identifies taxa sensitivity along eutrophication gradients (expressed as TP concentration), was also used to determine changes among study periods. In 2000-2004, E-SF values ranged between 0.19 and 0.69 ( 0.33 , on average) when sensitive taxa dominated the phytoplankton (Table 7). In 2005-2014, its values were higher, ranging between 0.03 and 3.85 (1.59, on average). The highest values (over 3.00) were recorded in 2005-2008, when tolerant taxa such as $A$. incerta, M. aeruginosa, U. acus, and U. ulna dominated the phytoplankton distinctly.

\section{Competition and grazing}

Competition for light and nutrients and possible allelopathic activities in phytoplankton-macrophyte relations occurred very often in the lake ecosystem. Assessments of long-term changes in the modified

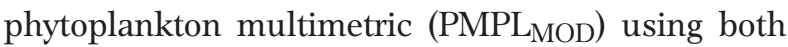
historical and current data confirmed considerable changes in water quality. These had a direct relationship with the changes in submerged macrophyte (SM) communities because of competition and potential allelopathy and diversified fish pressure because of grazing. During the 1967-2014 period, with the very strong temporal influence of fish, the submerged macrophytes tended to dominate, disappear, re-colonize, and then re-dominate. PMPL $L_{M O D}$ values indicated that the ecological status of the lake was high and good simultaneously with the domination of submerged macrophytes, primarily the angiosperms $C$. demersum and $E$. canadensis in 1967-1974 (Fig. 12), when common carp and even grass carp introductions began. The next lake stage included the disappearance of SM (1976-1992) from the high pressure of grass carp with biomass of up to $140 \mathrm{~kg} \mathrm{ha}^{-1}$ in 1976, and silver carp and bighead carp with biomass of up to $600 \mathrm{~kg} \mathrm{ha}^{-1}$ in 1992 . The lake ecological status was primarily moderate with 


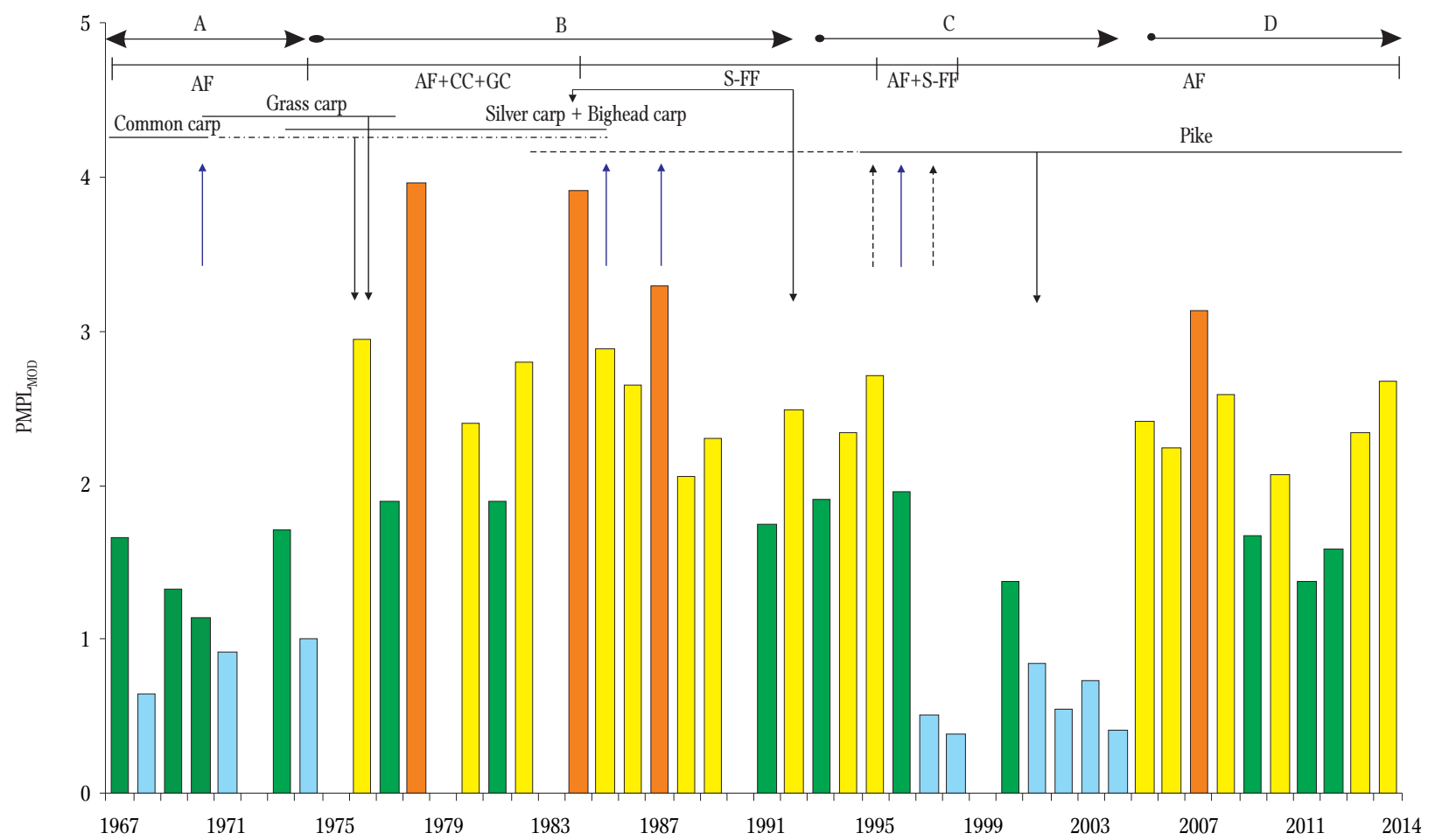

Figure 12. Phytoplankton response to changes in submerged macrophyte in 1967-1998 (historical data according to Spodniewska and Hillbricht-Ilkowska 1973, Węgleńska et al. 1979, Krzywosz 1999, Zdanowski et al. 1999, Bałdyga 2008, Hutorowicz and Dziedzic 2008) and 2000-2014 (current data) against the background of main fish introductions and stocking (horizontal lines: continuous for regular and intermittent for irregular) and fish pressure (horizontal line segments); PMPL $\mathrm{MOD}_{-}$- modified Phytoplankton Metric for Polish Lakes (according to Napiórkowska-Krzebietke 2015), classification of ecological status: 0-1 - high (blue); 1-2 - good (green); 2-3 - moderate (yellow); 3-4 - poor (orange). Black arrows indicate years with maximum fish biomass, blue arrows - winter fish kills, dashed black arrows - intensive fish exploitation. A - domination of submerged macrophytes, primarily Ceratophyllum demersum and Elodea canadensis; B - disappearance of submerged macrophytes (only isolated specimens); C - re-colonization of submerged macrophytes and dense phytocoenoses with dominant Chara globularis, C. rudis, C. demersum; D - disappearance of Charales, residual phytocoenoses of other submerged macrophytes or single specimens. Fish pressure type: AF - autochthonous fish; CC - common carp; GC - grass carp; $\mathrm{S}-\mathrm{FF}$ - seston-feeding fish.

a few periods when it was either good or even poor. After the re-colonization of submerged macrophytes (primarily the charophytes Chara globularis and $C$. rudis) in 1993-1996, the lake ecological status remained either good or moderate. However, in 1997-2004 when the charophyte phytocoenoses were dense and fish pressure was significantly reduced, the PMPL ${ }_{M O D}$ indicated that the lake status was high or good. In 2005, the Charales disappeared and the ecological status of the lake immediately worsened to moderate or poor, and this situation lasted until 2008. This shift toward a worse status was connected with cyanobacteria-dominated phytoplankton. In subsequent years, the phytoplankton structure shifted again toward dinoflagellate, cryptophyte, and diatom domination, and the ecological status of the lake fluctuated between good and moderate.

Phytoplankton-zooplankton relations were also affected by high or low fish pressure, which came primarily from silver carp and bighead carp. The long-term average summer zooplankton and phytoplankton biomass determined using historical published and current data showed that changes were of a relatively high amplitude (Fig. 13). In the summers of 1967-1998, the average phytoplankton biomass ranged from 1.3 to $27.5 \mathrm{mg} \mathrm{dm}^{-3}$ (Spodniewska and Hillbricht-Ilkowska 1973, Węgleńska et al. 1979, Krzywosz 1999, Zdanowski et al. 1999), and the average zooplankton biomass 


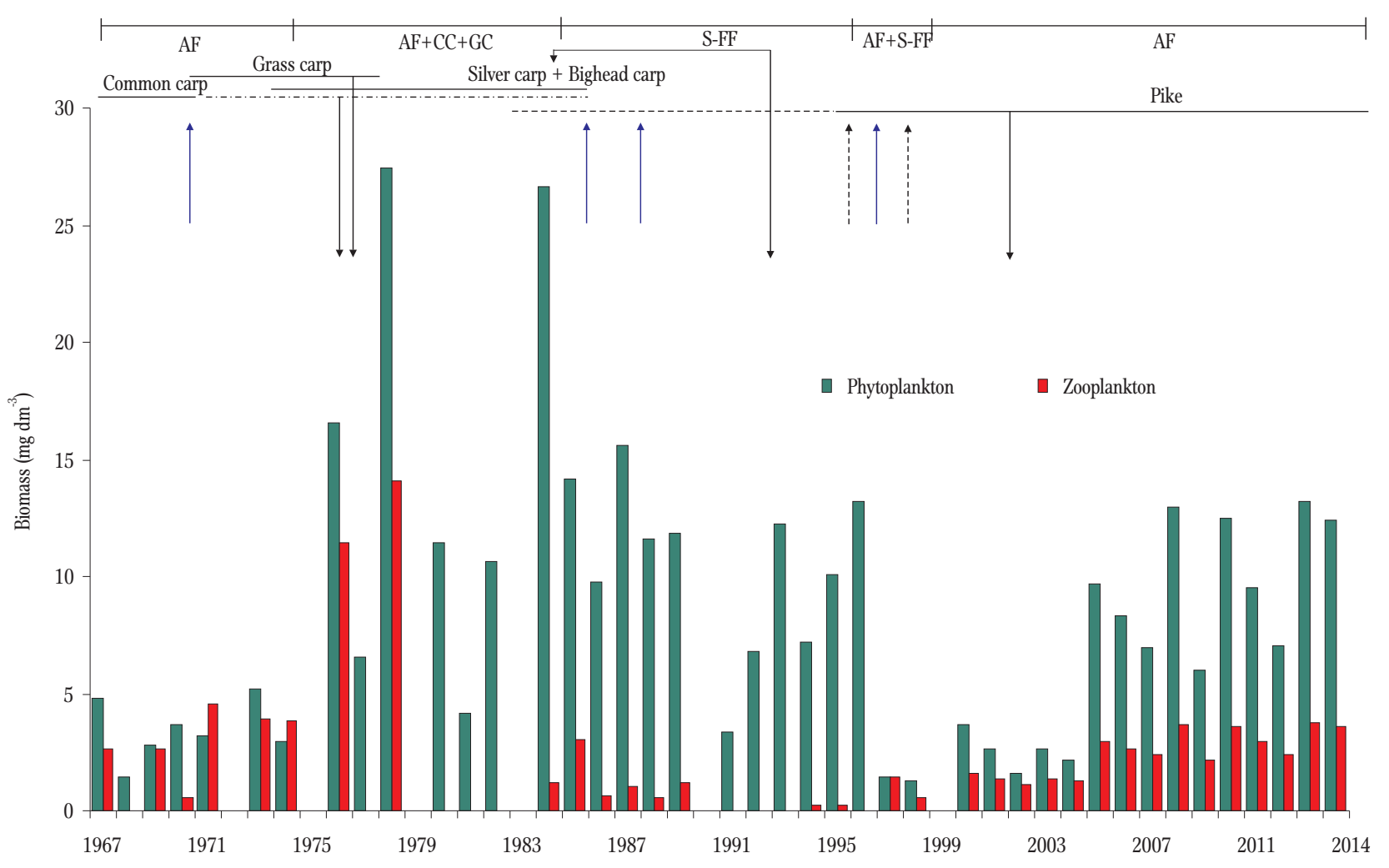

Figure 13. Average summer phytoplankton and zooplankton biomass against the background of fish introductions, stocking and pressure based on historical (1967-1998; Zdanowski et al. 1999) and current data (2000-2014; Zakęś et al. 2015), calculated potential zooplankton biomass (PZB) in 2000-2014. Black arrows indicate the year with maximum fish biomass; blue arrows - winter fish kills; dashed black arrows - intensive fish exploitation. Fish pressure (horizontal line segments) type: AF - autochthonous fish; CC - common carp; GC - grass carp; S-FF - seston-feeding fish.

Table 10

Zooplankton representatives recorded during the quantitative analyses of phytoplankton samples in selected years

\begin{tabular}{|c|c|c|c|c|c|}
\hline Taxonomic group & Species $^{1}$ & 2009 & 2010 & 2011 & 2012 \\
\hline \multirow[t]{3}{*}{ Cladocera } & Bosmina cf longirostris & + & - & - & - \\
\hline & Daphnia sp. & - & - & - & + \\
\hline & Diaphanosoma sp. & - & + & - & - \\
\hline \multirow[t]{2}{*}{ Copepoda } & Cyclops sp. & + & + & - & + \\
\hline & unidentified nauplii & + & + & + & + \\
\hline \multirow[t]{11}{*}{ Rotifera } & Ascomorpha sp. & + & + & + & + \\
\hline & Asplanchna cf priodonta & + & + & - & + \\
\hline & Brachionus angularis & + & + & - & + \\
\hline & Filinia longiseta & - & - & + & - \\
\hline & Kellicottia longispina & + & - & - & - \\
\hline & Keratella cochlearis & + & + & + & + \\
\hline & Keratella tecta & + & - & - & + \\
\hline & Keratella quadrata & + & + & + & - \\
\hline & Polyarthra sp. & + & + & + & + \\
\hline & Synchaeta sp. & - & + & - & - \\
\hline & Trichocerca sp. & + & + & - & - \\
\hline
\end{tabular}

${ }^{1}$ Current taxonomic names according to World Register of Marine Species (WoRMS Editorial Board 2017) and Rotifer World Catalog $(+)$ present or (-) absent taxon in phytoplankton samples 
ranged from 0.3 to $14.1 \mathrm{mg} \mathrm{dm}^{-3}$ (Tunowski 2006, 2009, Zdanowski et al. 1999). This period included both low and high seston-feeding fish pressure, and the linear relationship $(r=0.495)$ between phytoplankton and zooplankton recorded was significant. These relationships permitted devising a formula to calculate the potential zooplankton biomass (PZB) that was applied for the 2000-2014 period when the seston-feeding fish biomass was reduced and stocking was done primarily with pike. Generally, the higher phytoplankton biomass in 2005-2014 than in 2000-2004 was accompanied by higher zooplankton biomass, which was similar to that of the 1970s, when the biomasses of both introduced Cyprinidae species were relatively low. With regard to the potential zooplankton structure, some representatives of filter feeders, such as large-sized cladocerans of the genera Daphnia, Diaphanosoma, and Bosmina and copepods of the genus Cyclops, were noted only sporadically (only single specimens were noted in phytoplankton samples) during quantitative phytoplankton analyses (Table 10). On the other hand, small-sized rotifers of the genera Keratella (primarily K. cochlearis (Gosse)), Ascomorpha, and Polyarthra were noted very often in phytoplankton samples. Other species, such as $K$. tecta (Gosse), K. quadrata (Müller)), Brachionus angularis Gosse, and Asplanchna priodonta Gosse, were noted relatively often, while Filinia longiseta (Ehrenberg) and Kellicottia longispina (Kellicott) were noted only occasionally.

The analyses of long-term changes in the average summer biomasses of phytoplankton and zooplankton indicated that they were the highest in 1975-1984 (Table 11). In subsequent years, phytoplankton biomass gradually decreased to the level of approximately $2.6 \mathrm{mg} \mathrm{dm}^{-3}$, which was recorded in 2000-2004, after which time it increased to above $9.0 \mathrm{mg} \mathrm{dm}^{-3}$. Zooplankton biomass was characterized by a rapid drop from $8.9 \mathrm{mg} \mathrm{dm}^{-3}$ to approximately $1.0 \mathrm{mg} \mathrm{dm}^{-3}$ in the $1980 \mathrm{~s}$ and 1990s. In subsequent years, summer zooplankton biomass (expressed as PZB) was 1.4 and $3.0 \mathrm{mg} \mathrm{dm}^{-3}$, on average, in 2000-2004 and 2005-2014, respectively. The trophic efficiency (TE) of the planktonic food web was calculated as the ratio of zooplankton biomass to phytoplankton biomass in the summer period (Table 11). TE values ranged between 0.10 and 0.89 in all periods with considerable changes in eutrophication proxies (for example, expressed as TP and SDD). Thus, a new trophic efficiency classification was proposed: class I - 0-0.20; class II 0.21-0.40; class III - 0.41-0.60; class IV - 0.61-0.80; class $\mathrm{V}-0.81-1.00$. According to the proposed

Table 11

Trophic efficiency based on average summer phytoplankton and zooplankton biomass with eutrophication proxies and fish pressure (\% of total biomass) in Lake Warniak in 1967-2014

\begin{tabular}{|c|c|c|c|c|c|c|c|c|c|c|}
\hline \multirow[b]{2}{*}{ Periods } & \multirow{2}{*}{$\frac{\mathrm{TP}}{\left(\mathrm{mg} \mathrm{dm}^{-3}\right)}$} & \multirow{2}{*}{$\begin{array}{l}\text { SDD } \\
(\mathrm{m})\end{array}$} & \multirow{2}{*}{$\frac{P B}{\left(m g d m^{-3}\right)}$} & \multirow{2}{*}{$\frac{\mathrm{ZB}}{\left(\mathrm{mg} \mathrm{dm}^{-3}\right)}$} & \multirow{2}{*}{$\begin{array}{l}\text { Trophic } \\
\text { efficiency }^{1}\end{array}$} & \multirow[b]{2}{*}{ Class $^{2}$} & \multicolumn{4}{|c|}{ Fish pressure (\%) } \\
\hline & & & & & & & All AF & $\mathrm{CC}+\mathrm{GC}$ & S-FF & Type \\
\hline 1967-1974 & n.d. & 2.0 & 3.46 & 3.06 & 0.89 & $\mathrm{~V}$ & 72 & 27 & 1 & $\mathrm{AF}$ \\
\hline 1975-1984 & 0.141 & 0.6 & 14.83 & 8.93 & 0.60 & III & 48 & 41 & 11 & $\mathrm{AF}+\mathrm{CC}+\mathrm{GC}$ \\
\hline 1985-1994 & 0.111 & 0.8 & 10.30 & 1.03 & 0.10 & I & 15 & 2 & 83 & S-FF \\
\hline 1995-1998 & 0.087 & 1.7 & 6.53 & 0.76 & 0.12 & I & 56 & 2 & 42 & $\mathrm{AF}+\mathrm{S}-\mathrm{FF}$ \\
\hline 2000-2004 & 0.074 & 2.2 & 2.57 & $1.10^{3}$ & 0.43 & III & 84 & 1 & 15 & $\mathrm{AF}$ \\
\hline 2005-2014 & 0.095 & 1.8 & 9.90 & $2.92^{3}$ & 0.30 & II & 89 & $>1$ & 10 & $\mathrm{AF}$ \\
\hline
\end{tabular}

TP - total phosphorus, SDD - Secchi disk depth, PB - phytoplankton biomass, ZB - zooplankton biomass, AF - autochthonous fish, CC - common carp, GC - grass carp, S-FF - seston-feeding fish

${ }^{1}$ Trophic efficiency (TE) - the ratio of zooplankton biomass to phytoplankton biomass in summer (according to Hilbricht-Ilkowska and Kajak 1986)

${ }^{2}$ Proposed classification of trophic efficiency: I - 0-0.20, II - 0.21-0.40, III - 0.41-0.60, IV - 0.61-0.80, V - 0.81-1.00

${ }^{3} \mathrm{PZB}$ - potential zooplankton biomass calculated for 2000-2014

Data on TP, SDD, PB and ZB for 1967-1998 according to Spodniewska and Hilbricht-Ilkowska 1973, Zachwieja 1973, Spodniewska 1975, Węgleńska et al. 1979, Karpiński 1994, Krzywosz 1999, Zdanowski et al. 1999, Tunowski 2006, 2009 
classification, four of the five TE classes (I, II, III and V) were identified in Lake Warniak. The lowest TE value (0.10, class I) was recorded in the 1985-1994 period because of the higher TP content and lower Secchi disk depth, while the pressure of seston-feeding fish (S-FF) was the highest. A very similar TE value was also in the next period with a high share of S-FF in ichthyofauna but with less TP content and higher SDD. The 1975-1984 period, with the highest average summer biomass of both phytoplankton and zooplankton, the highest TP content, the lowest SDD and relatively high TE of 0.60 class III, was exceptional because of the high pressure of benthophagous common carp and herbivorous grass carp. A TE value of 0.43 (class III) was recorded in 2000-2004 when the lowest TP content and the highest SDD were noted, and the ichthyofauna was dominated by autochthonous species. The highest trophic efficiency (0.89, class V) was in 1967-1974 when water quality was good and autochthonous fish dominated.

\section{Nutrient-phytoplankton-zooplankton -macrophyte-fish interactions}

Interrelations between phytoplankton features including the biomass of each phylum, the total biomass, and chlorophyll $a$ content based on current data (from 2000-2014) were tested with Spearman's rank correlation coefficient. The results indicated statistically significant positive dependencies in almost all cases (Table 12). The only exception were cryptophytes, which were significantly (but negatively) correlated with cyanobacteria, diatoms, and planktonic charophytes, whereas correlations were not significant with regard to other phytoplankton features. Positive, significant correlations in phytoplankton relationships with selected environmental parameters during 2000-2014 were identified primarily for water

Table 12

Spearman correlation coefficient between phytoplankton and environmental parameters in Lake Warniak (2000-2014)

\begin{tabular}{|c|c|c|c|c|c|c|c|c|c|c|}
\hline & CYA & BAC & CHA & CHL & CRY & EUG & MIO & $\mathrm{OCH}$ & TB & Chl- $a$ \\
\hline CYA & - & 0.50 & $\begin{array}{l}0.77 \\
\end{array}$ & 0.67 & $\begin{array}{l}-0.36 \\
\end{array}$ & 0.50 & 0.48 & 0.35 & 20.68 & 0.47 \\
\hline BAC & 0.50 & - & 0.54 & 0.50 & -0.22 & 0.46 & 0.36 & 0.62 & 0.56 & 0.51 \\
\hline CHA & 0.66 & 0.54 & - & 0.67 & -0.30 & 0.42 & 0.35 & 0.30 & 0.60 & 0.48 \\
\hline CHL & 0.67 & 0.50 & 0.67 & - & n.s. & 0.50 & 0.60 & 0.37 & 0.67 & 0.51 \\
\hline CRY & -0.36 & -0.22 & -0.30 & n.s. & - & n.s. & n.s. & n.s. & n.s. & n.s. \\
\hline EUG & 0.50 & 0.46 & 0.42 & 0.50 & n.s. & - & 0.44 & 0.26 & 0.43 & 0.41 \\
\hline MIO & 0.48 & 0.36 & 0.35 & 0.60 & n.s. & 0.44 & - & 0.37 & 0.68 & 0.42 \\
\hline $\mathrm{OCH}$ & 0.35 & 0.62 & 0.30 & 0.37 & n.s. & 0.26 & 0.37 & - & 0.51 & 0.47 \\
\hline $\mathrm{TB}$ & 0.68 & 0.56 & 0.60 & 0.67 & n.s. & 0.43 & 0.68 & 0.51 & - & 0.62 \\
\hline Chl- $a$ & 0.47 & 0.51 & 0.48 & 0.51 & n.s. & 0.41 & 0.42 & 0.47 & 0.62 & - \\
\hline $\mathrm{T}$ & 0.61 & n.s. & 0.50 & 0.61 & n.s. & 0.34 & 0.46 & n.s. & 0.47 & n.s. \\
\hline DO & -0.38 & n.s. & -0.42 & -038 & n.s. & -0.25 & n.s. & n.s. & n.s. & n.s. \\
\hline SDD & -0.59 & -0.57 & -0.62 & -0.66 & 0.26 & -0.54 & -0.40 & -0.43 & -0.64 & -0.61 \\
\hline $\mathrm{NH}_{4}-\mathrm{N}$ & n.s. & n.s. & n.s. & n.s. & n.s. & n.s. & n.s. & n.s. & n.s. & n.s. \\
\hline $\mathrm{NO}_{2}-\mathrm{N}$ & n.s. & n.s. & n.s. & n.s. & n.s. & n.s. & n.s. & n.s. & -0.22 & n.s. \\
\hline $\mathrm{NO}_{3}-\mathrm{N}$ & n.s. & n.s. & n.s. & n.s. & n.s. & n.s. & n.s. & n.s. & n.s. & n.s. \\
\hline $\mathrm{TN}$ & n.s. & n.s. & n.s. & n.s. & n.s. & n.s. & n.s. & n.s. & n.s. & n.s. \\
\hline $\mathrm{N}_{\text {org }}$ & 0.33 & n.s. & n.s. & n.s. & n.s. & n.s. & n.s. & n.s. & n.s. & 0.32 \\
\hline $\mathrm{PO}_{4}-\mathrm{P}$ & 0.30 & 0.23 & 0.33 & n.s. & -0.22 & n.s. & n.s. & n.s. & 0.27 & n.s. \\
\hline $\mathrm{TP}$ & 0.23 & n.s. & 0.23 & n.s. & n.s. & n.s. & n.s. & n.s. & n.s. & 0.23 \\
\hline $\mathrm{P}_{\text {org }}$ & n.s. & n.s. & n.s. & n.s. & n.s. & n.s. & n.s. & n.s. & n.s. & 0.26 \\
\hline TLI & 0.58 & 0.57 & 0.60 & 0.58 & -0.28 & 0.39 & 0.36 & 0.45 & 0.64 & 0.81 \\
\hline
\end{tabular}

Statistically significant correlations at $\mathrm{P}<0.05 ; \mathrm{n}=100$, n.s. - not significant

CYA - Cyanobacteria, BAC - Bacillariophyta, CHA - planktonic Charophyta, CHL - Chlorophyta, CRY - Cryptophyta, EUG Euglenozoa, MIO - Miozoa, OCH - Ochrophyta, TB - total biomass, Chl- $a$ - chlorophyll $a$, T - water temperature, DO - dissolved oxygen, SDD - Secchi disk depth, $\mathrm{NH}_{4}-\mathrm{N}$ - ammonium nitrogen, $\mathrm{NO}_{2}-\mathrm{N}$ - nitrite nitrogen, $\mathrm{NO}_{3}-\mathrm{N}$ - nitrate nitrogen, $\mathrm{TN}$ - total nitrogen, $\mathrm{N}_{\text {org }}$ - organic nitrogen, $\mathrm{PO}_{4}-\mathrm{P}$ - phosphates, $\mathrm{TP}$ - total phosphorus, $\mathrm{P}_{\text {org }}$ - organic phosphorus, TLI - Trophic Level Index 


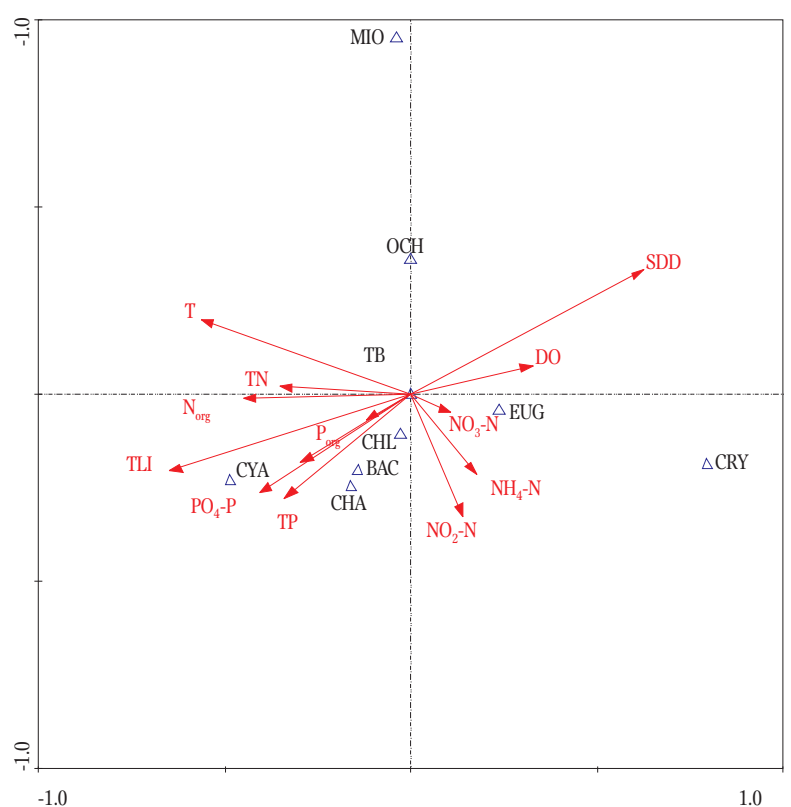

Figure 14. Biplot of Canonical Correspondence Analysis (CCA) showing relationships between phytoplankton and selected environmental variables (based on data from the entire growth seasons in 2000-2014) in Lake Warniak; CYA - Cyanobacteria; BAC - Bacillariophyta; CHA - Charophyta; CHL - Chlorophyta; CRY Cryptophyta; EUG - Euglenozoa; MIO - Miozoa; OCH Ochrophyta; TB - total biomass; T - water temperature; DO - dissolved oxygen; SDD - Secchi disk depth; $\mathrm{NH}_{4}-\mathrm{N}$ - ammonium nitrogen $\mathrm{NO}_{2}-\mathrm{N}$ - nitrite nitrogen; $\mathrm{NO}_{3}-\mathrm{N}$ - nitrate nitrogen; TN total nitrogen; $\mathrm{N}_{\text {org }}$ - organic nitrogen; $\mathrm{PO}_{4}-\mathrm{P}$ - phosphates; $\mathrm{TP}$ total phosphorus; $\mathrm{P}_{\text {org }}$ - organic phosphorus; TLI - Trophic Level Index. temperature and cyanobacteria, charophytes, chlorophytes, euglenophytes, dinoflagellates, and total biomass. Positive relationships were also noted, for example, between phosphorus and cyanobacteria, diatoms and chlorophyll $a$, and also among almost all phytoplankton groups (except for cryptophytes with negative correlations), total biomass, chlorophyll $a$, and trophic index TLI. Significantly negative correlations were noted for Secchi disk depth (SDD) and phytoplankton features, except for cryptophytes (positive correlations). Phytoplankton-environment relationships throughout the growth season in 2000-2014 were also verified using CCA analysis. The eigenvalues of the first two axes were 0.252 and 0.213 , respectively. The first two axes represented $25 \%$ and $22 \%$, and $28 \%$ and $24 \%$ of the total variation for phytoplankton groups and phytoplankton-environment relations, respectively. This analysis primarily confirmed that SDD was negatively correlated with cyanobacteria, planktonic charophytes, diatoms, and chlorophytes, and it was positively correlated with cryptophytes (Fig. 14). In contrast, positive relations were noted with dinoflagellates and ochrophytes, and the negative impact of temperature on cryptophytes was stronger.

Phytoplankton had a negative effect on water transparency, submerged macrophytes and autochthonous fish in Lake Warniak throughout the 47-year study (1967-2014) (Table 13).

Table 13

R-Spearman correlation coefficient among phytoplankton features (including biomass, chlorophyll $a$ content, and phytoplankton index) and the selected parameters in Lake Warniak (1967-2014)

\begin{tabular}{|c|c|c|c|c|c|c|c|c|c|c|c|c|}
\hline $\begin{array}{l}\text { Phytoplankton } \\
\text { features }\end{array}$ & $\mathrm{T}$ & SDD & $\mathrm{NH}_{4}-\mathrm{N}$ & $\mathrm{NO}_{3}-\mathrm{N}$ & $\mathrm{TN}$ & $\mathrm{PO}_{4}-\mathrm{P}$ & $\mathrm{TP}$ & SMB & $\mathrm{AFB}$ & IFB & S-FFB & GCB \\
\hline Total biomass & n.s. & -0.748 & 0.404 & n.s. & n.s. & n.s. & n.s. & -0.616 & -0.554 & 0.439 & 0.324 & 0.361 \\
\hline $\begin{array}{l}\text { Summer } \\
\text { biomass }\end{array}$ & n.s. & -0.686 & 0.400 & n.s. & n.s. & 0.349 & 0.335 & -0.613 & -0.425 & n.s. & n.s. & n.s. \\
\hline Cyanobacteria & n.s. & -0.591 & n.s. & n.s. & n.s. & 0.370 & 0.434 & -0.574 & n.s. & n.s. & n.s. & n.s. \\
\hline Chlorophyll $a$ & n.s. & -0.862 & n.s. & n.s. & n.s. & n.s. & 0.420 & -0.759 & -0.484 & 0.484 & n.s. & 0.726 \\
\hline PMPL $_{\text {MOD }}$ & n.s. & -0.735 & 0.410 & n.s. & n.s. & 0.394 & 0.438 & -0.675 & -0.432 & 0.394 & 0.330 & 0.339 \\
\hline
\end{tabular}

Statistically significant correlations at $\mathrm{P}<0.05, \mathrm{n}=48$, n.s. - not significant

$\mathrm{T}$ - water temperature, SDD - Secchi disk depth, $\mathrm{NH}_{4}-\mathrm{N}$ - ammonium nitrogen, $\mathrm{NO}_{3}-\mathrm{N}$ - nitrate nitrogen, TN - total nitrogen, $\mathrm{PO}_{4}-\mathrm{P}$ - phosphates, TP - total phosphorus, SMB - submerged macrophyte biomass, AFB - autochthonous fish biomass, IFB -

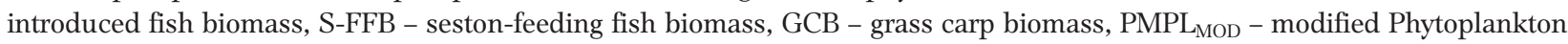
Metric for Polish Lakes (Napiórkowska-Krzebietke 2015) 


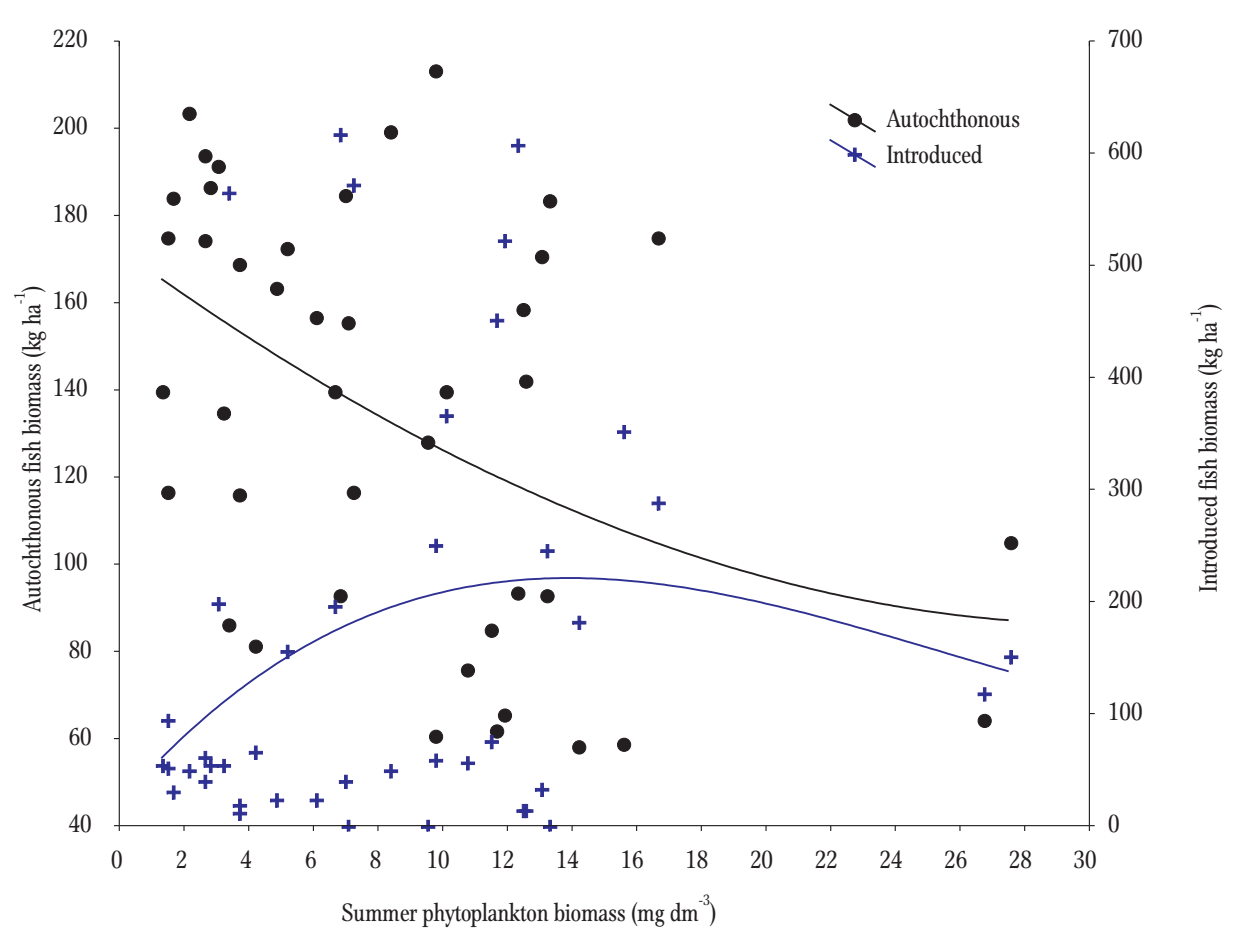

Figure 15. Fish-phytoplankton relationship based on biomass of autochthonus fish and introduced fish and summer phytoplankton biomass according to Spodniewska and Hilbricht-Ilkowska (1973), Spodniewska (1975), Węgleńska et al. (1979), Zdanowski et al. (1999), Chybowski (unpublished data), current data.

Phytoplankton growth was enhanced (significant positive correlations) primarily by the concentration of ammonium nitrogen and phosphorus (including both phosphates and TP). The biomass of all the introduced fish and the individual biomass of grass carp were positively correlated with total phytoplankton biomass, chlorophyll $a$, and PMPL $L_{M O D}$, whereas seston-feeding fish biomass was positively correlated with TB and PMPLMOD. No significant correlations were noted with water temperature, nitrates, total nitrogen, or zooplankton biomass (a significant correlation was only noted for 1967-1998). The summer phytoplankton-fish relationships with a significant negative correlation $(\mathrm{r}=-0.431 ; \mathrm{P}=0.004)$ for autochthonous fish and a positive, but statistically insignificant, correlation $(\mathrm{r}=0.178, \mathrm{P}=0.259)$ for introduced fish were the basis for modelling trends, as is shown in Figure 15.

Biological and physicochemical elements were also correlated using Principal Component Analysis. The first two components explained $62 \%$ of the total variability (Fig. 16). Phytoplankton (i.e., total biomass, cyanobacterial biomass) was strongly negatively correlated with PC1, which explained 36\% of the total variability. Similar relationships were also identified for chlorophyll $a$, selected forms of phosphorus, nitrogen, and grass carp biomass, whereas opposite relationships were noted for SDD. For the second component of PC2 (26\%), positively correlated parameters included introduced fish, zooplankton, water temperature, and dissolved oxygen, whereas negatively correlated parameters included ammonium nitrogen.

By implementing the varimax rotation in PCA and an eigenvalue-greater-than-one criterion, it was possible to associate each variable with only one factor, or rotated component, and split it into six disjoint factors that explained over $96 \%$ of the total variability (Table 14). The first two rotated components explained only $46 \%$ of the total variability and emphasized zooplankton-fish-phytoplankton relationships. Factor 1, which explained $25 \%$ of the total variability, referred to strong positive loadings of zooplankton (0.98), fish (common carp and grass carp; 0.97), 


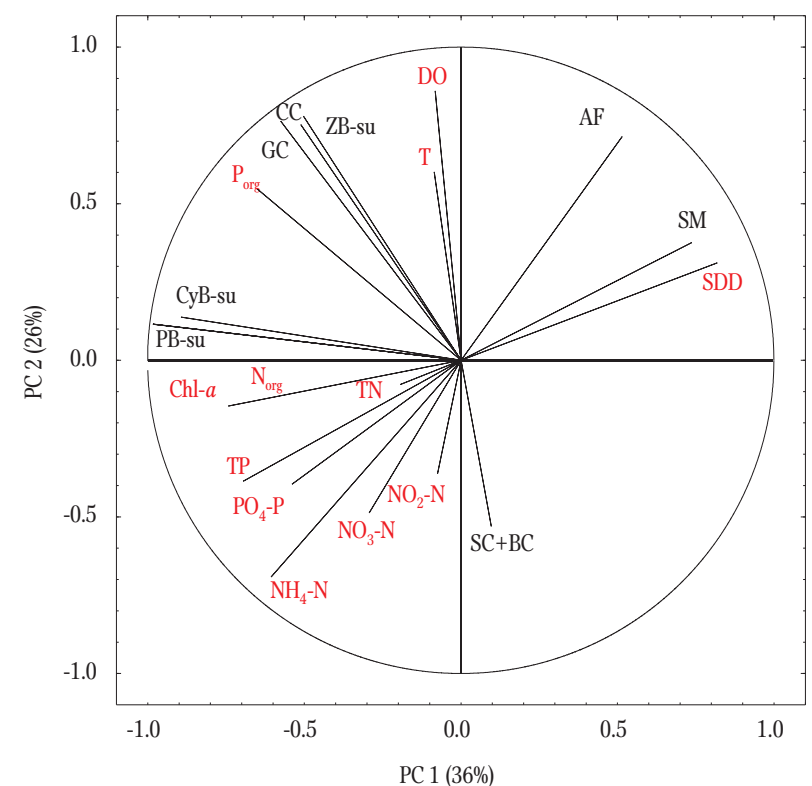

Figure 16. PCA ordination diagram based on phytoplankton-environment relations; $\mathrm{PB}-\mathrm{su}$ - summer phytoplankton; CyB-su - summer cyanobacteria; ZB-su - summer zooplankton; CC common carp; GC - grass carp; SC+BC - silver carp + bighead carp; AF - autochthonous fish; $\mathrm{SM}$ - submerged macrophytes; Chl- $a$ - chlorophyll $a$; T - water temperature; DO - dissolved oxygen; SDD - Secchi disk depth; $\mathrm{NH}_{4}-\mathrm{N}$ - ammonium nitrogen; $\mathrm{NO}_{2}-\mathrm{N}$ - nitrite nitrogen; $\mathrm{NO}_{3}-\mathrm{N}$ - nitrate nitrogen; $\mathrm{TN}$ - total nitrogen; $\mathrm{N}_{\text {org }}$ - organic nitrogen; $\mathrm{PO}_{4}-\mathrm{P}$ - phosphates; $\mathrm{TP}$ - total phosphorus.

phytoplankton, and $\mathrm{P}_{\text {org }}(0.62-0.65)$. Strong correlations with factor 2 , which explained $21 \%$ of the total variability, included autochthonous fish, submerged macrophytes, and SDD (negative), and seston-feeding fish and phosphates (positive). The correlations of the remaining parameters were as follows: chlorophyll $a$ and phosphorus (TP, $\mathrm{P}_{\text {org }}$ ) were strongly positively correlated with factor 3 (19\% of the total variability); temperature and dissolved oxygen were negatively and mineral nitrogen was positively correlated with factor $4(14 \%$ of the total variability); $\mathrm{TN}$ and $\mathrm{N}_{\text {org }}$ were positively correlated with factor 5 ( $11 \%$ of the total variability); nitrite was negatively correlated with factor 6 (only $6 \%$ of the total variability). CCA analysis also verified some significant relationships among selected biological and

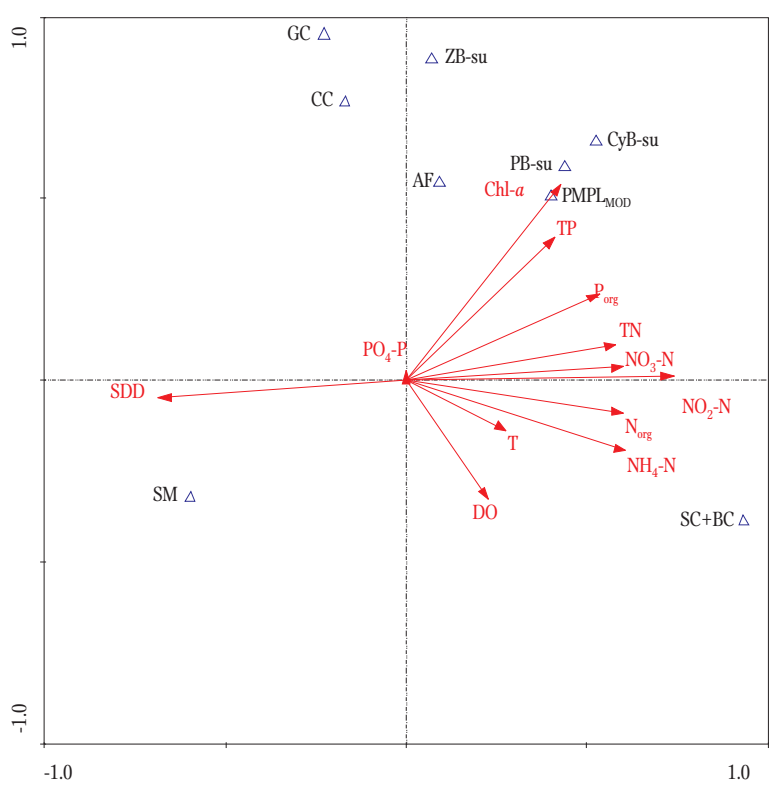

Figure 17. Biplot of Canonical Correspondence Analysis (CCA) showing relationships among selected biological and environmental variables. $\mathrm{PB}-\mathrm{su}$ - summer phytoplankton; CyB-su - summer cyanobacteria; ZB-su - summer zooplankton; CC - common carp; GC - grass carp; SC+BC - silver carp + bighead carp; AF autochthonous fish; SM - submerged macrophytes; PMPL ${ }_{\mathrm{MOD}}-$ modified Phytoplankton Metric for Polish Lakes; Chl- $a$ - chlorophyll $a$; T - water temperature; DO - dissolved oxygen; SDD Secchi disk depth; $\mathrm{NH}_{4}-\mathrm{N}$ - ammonium nitrogen; $\mathrm{NO}_{2}-\mathrm{N}$ - nitrite nitrogen; $\mathrm{NO}_{3}-\mathrm{N}$ - nitrate nitrogen; $\mathrm{TN}$ - total nitrogen; $\mathrm{N}_{\text {org }}$ - organic nitrogen; $\mathrm{PO}_{4}-\mathrm{P}$ - phosphates; $\mathrm{TP}$ - total phosphorus; $\mathrm{P}_{\text {org }}-$ organic phosphorus.

physicochemical variables (Fig. 17). The eigenvalues of the first two axes were 0.583 and 0.356 , respectively. The first two axes represented $48 \%, 21 \%$ and $50 \%, 30 \%$ of the total variation for biological data and biological-physicochemical relationships, respectively. Significant positive correlations were also identified between phytoplankton, zooplankton, fish, and chlorophyll $a$ and phosphorus, whereas the relationships with submerged macrophytes and SDD were negative. The phytoplankton-nitrogen relationship was weaker.

Phytoplankton-zooplankton-fish relations were also checked for the arrangement of samples using PCA. The first two factors (PC1 and PC2) explained approximately $71 \%$ of the total variability. The PCA plot showed a distinct grouping of the years studied 
Table 14

Principal Components Analysis loadings (after orthogonal varimax rotation and original)

\begin{tabular}{|c|c|c|c|c|c|c|}
\hline \multirow[b]{2}{*}{ Parameters } & \multicolumn{6}{|c|}{ Varimax-rotated PCA components } \\
\hline & Factor 1 & Factor 2 & Factor 3 & Factor 4 & Factor 5 & Factor 6 \\
\hline Zooplankton (summer) & $0.98^{*}$ & -0.01 & 0.01 & -0.14 & -0.04 & 0.06 \\
\hline Common carp & $0.97^{*}$ & -0.01 & -0.02 & -0.21 & 0.06 & 0.06 \\
\hline Grass carp & $0.97^{*}$ & -0.02 & 0.10 & -0.19 & 0.07 & 0.08 \\
\hline Autochthonous fish & 0.21 & $-0.91^{*}$ & -0.26 & -0.13 & -0.04 & 0.10 \\
\hline Seston-feeding fish & -0.51 & $0.69^{*}$ & -0.19 & -0.41 & 0.10 & -0.23 \\
\hline Submerged macrophytes & -0.24 & $-0.89^{*}$ & -0.20 & -0.10 & -0.16 & 0.02 \\
\hline Phytoplankton & $0.62 *$ & 0.43 & 0.58 & 0.06 & 0.28 & -0.01 \\
\hline Phytoplankton (summer) & $0.62 *$ & 0.43 & 0.58 & 0.06 & 0.28 & -0.01 \\
\hline Cyanobacteria (summer) & $0.65^{*}$ & 0.18 & 0.50 & 0.28 & 0.44 & -0.13 \\
\hline Chlorophyll $a$ & 0.04 & 0.17 & $0.95^{*}$ & 0.05 & 0.18 & 0.08 \\
\hline Temperature & 0.21 & 0.03 & 0.12 & $-0.93^{*}$ & 0.09 & 0.21 \\
\hline Dissolved oxygen & 0.47 & -0.48 & 0.25 & $-0.67^{*}$ & -0.11 & -0.13 \\
\hline Secchi depth & -0.13 & $-0.72^{*}$ & $-0.66^{*}$ & 0.06 & 0.05 & 0.05 \\
\hline Total nitrogen & 0.08 & 0.05 & -0.12 & 0.14 & $0.97^{*}$ & 0.04 \\
\hline Organic nitrogen & 0.08 & 0.01 & 0.58 & -0.06 & $0.78^{*}$ & 0.01 \\
\hline Ammonium nitrogen & -0.08 & 0.54 & 0.42 & $0.67^{*}$ & 0.17 & 0.04 \\
\hline Nitrite nitrogen & -0.15 & 0.21 & 0.01 & 0.01 & -0.01 & $-0.95^{*}$ \\
\hline Nitrate nitrogen & -0.16 & 0.01 & 0.37 & $0.76^{*}$ & 0.29 & 0.17 \\
\hline Phosphate & 0.26 & $0.77^{*}$ & 0.06 & 0.25 & -0.34 & -0.40 \\
\hline Total phosphorus & 0.10 & 0.33 & $0.73^{*}$ & 0.44 & -0.26 & -0.21 \\
\hline Organic phosphorus & $0.65^{*}$ & -0.06 & $0.64^{*}$ & -0.20 & -0.31 & 0.03 \\
\hline Eigenvalue & 5.27 & 4.33 & 4.09 & 3.04 & 2.39 & 1.32 \\
\hline Variance (\%) & 25 & 21 & 19 & 14 & 11 & 6 \\
\hline Cumulative (\%) & 25 & 46 & 65 & 79 & 90 & 96 \\
\hline \multirow{2}{*}{ Parameters } & \multicolumn{6}{|c|}{ Original PCA components } \\
\hline & Factor 2 & Factor 1 & Factor 5 & Factor 3 & Factor 4 & Factor 6 \\
\hline Zooplankton (summer) & $0.75^{*}$ & -0.50 & -0.36 & 0.13 & 0.12 & -0.05 \\
\hline Common carp & $0.78^{*}$ & -0.50 & -0.36 & 0.10 & 0.01 & -0.03 \\
\hline Grass carp & $0.76^{*}$ & $-0.58^{*}$ & -0.28 & 0.05 & 0.03 & -0.03 \\
\hline Autochthonous fish & -0.53 & 0.10 & 0.04 & $0.60 *$ & $-0.59^{*}$ & -0.01 \\
\hline Seston-feeding fish & $0.71^{*}$ & 0.52 & 0.01 & -0.36 & 0.18 & 0.16 \\
\hline Submerged macrophytes & 0.38 & 0.74 & 0.26 & -0.30 & 0.22 & 0.20 \\
\hline Phytoplankton & 0.12 & $-0.98^{*}$ & -0.04 & -0.04 & -0.10 & -0.01 \\
\hline Phytoplankton (summer) & 0.12 & $-0.98^{*}$ & -0.04 & -0.04 & -0.10 & -0.01 \\
\hline Cyanobacteria (summer) & 0.14 & $-0.89 *$ & -0.18 & -0.32 & -0.03 & 0.21 \\
\hline Chlorophyll $a$ & -0.15 & $-0.74^{*}$ & $0.59 *$ & -0.24 & 0.01 & -0.01 \\
\hline Temperature & $0.60^{*}$ & -0.09 & 0.37 & 0.36 & -0.55 & -0.20 \\
\hline Dissolved oxygen & $0.86^{*}$ & -0.08 & 0.38 & 0.17 & 0.05 & 0.26 \\
\hline Secchi depth & 0,31 & $0.82 *$ & -0.28 & -0.33 & 0.05 & 0.14 \\
\hline Total nitrogen & -0.08 & -0.19 & -0.37 & $-0.58^{*}$ & $-0.67^{*}$ & 0.14 \\
\hline Organic nitrogen & 0.01 & $-0.55^{*}$ & 0.27 & -0.51 & -0.52 & 0.20 \\
\hline Ammonium nitrogen & $-0.69 *$ & $-0.61^{*}$ & -0.10 & -0.25 & 0.16 & -0.12 \\
\hline Nitrite nitrogen & $-0,36$ & $-0,07$ & -0.06 & 041 & -0.03 & $0.82^{*}$ \\
\hline Nitrate nitrogen & -0.49 & -0.29 & -0.01 & $-0.69 *$ & 0.22 & -0.05 \\
\hline Phosphate & -0.40 & -0.54 & -0.33 & $0.60^{*}$ & 0.26 & 0.09 \\
\hline Total phosphorus & -0.39 & $-0.70^{*}$ & 0.25 & 0.03 & 0.48 & 0.12 \\
\hline Organic phosphorus & 0.55 & $-0.65^{*}$ & 0.34 & 0.15 & 0.34 & -0.01 \\
\hline Eigenvalue & 5.42 & 7.36 & 1.66 & 2.73 & 1.99 & 1.01 \\
\hline Variance (\%) & 26 & 36 & 8 & 13 & 9 & 5 \\
\hline Cumulative (\%) & 26 & 62 & 70 & 83 & 92 & 97 \\
\hline
\end{tabular}

*Strong positive or negative loadings at $\mathrm{P}<0.05, \mathrm{n}=48$ 

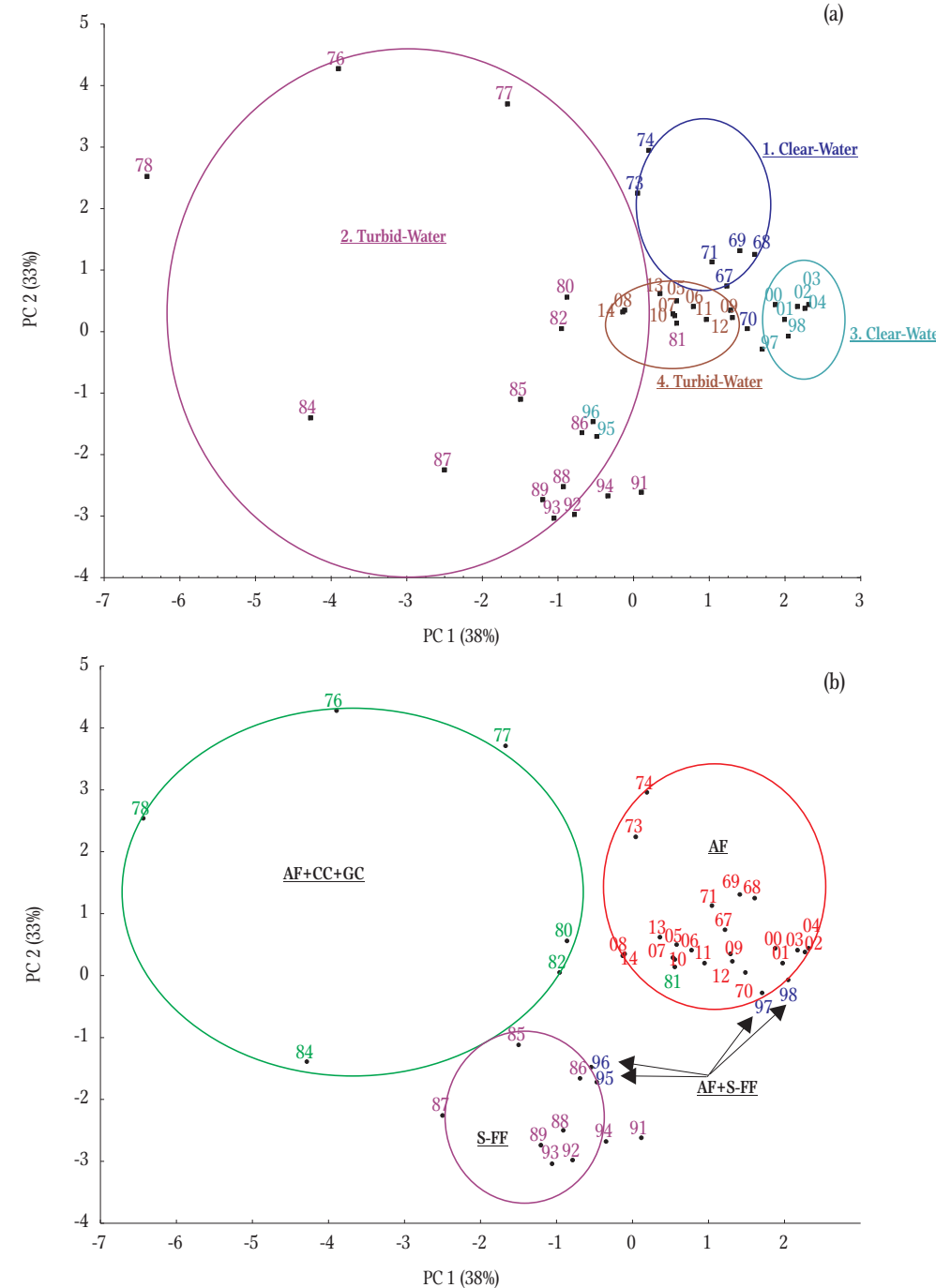

Figure 18. PCA plot based on phytoplankton-zooplankton-fish relations showing grouping of periods with clear-water $(1,3)$ and turbid-water $(2,4)$ states $(a$, where: 1 -1967-1974; 2 - 1975-1994; 3 - 1995-2004; 4 - 2005-2014) and main fish pressure (b, where: AF - 1967-1974 and 2000-2014; AF+CC+GC - 1975-1984; S-FF - 1985-1994; AF+S-FF - 1995-1998); AF - autochthonous fish; CC - common carp; GC - grass carp; S-FF - seston-feeding fish.

into four periods: two periods with submerged macrophyte domination and clear-water state (1967-1974 and 1995-2004) and two periods with phytoplankton domination and turbid-water state (1975-1994 and 2005-2014), which followed one after the other alternately (Fig. 18a). Considering the different types of fish pressure, the PCA plot indicated a high relationship between periods with autochthonous fish pressure, primarily the periods of 1967-1974, 2000-2004, and 2005-2014 (Fig. 18b).
The 1985-1994 period with seston-feeding fish pressure was a separate group. The 1975-1984 period, when multiple pressures of autochthonous fish and introduced common carp and grass carp were recorded, was the most variable.

\section{Discussion}

Global strategies for aquatic environmental management should be based on achieving and maintaining healthy, sustainable ecosystems. Currently, the quality or ecological state of many water bodies remains unsatisfactory, and although some restoration tools for improving quality are promising (e.g., Yu et al. 2016, Dondajewska et al. 2017, Rosińska et al. 2017, Sitarek et al. 2017), whereas others have failed to achieve this goal (Ofir et al. 2017). According to Kozak et al. (2015), applying two restoration methods (biomanipulation with pike, pike-perch, wels catfish and phosphorus inactivation) in a reservoir made it possible to decrease phosphorus concentrations, enhance zooplankton grazing, and change the phytoplankton structure, but these measures did not decrease phytoplankton biomass. In another case, the effects of three restoration methods (phosphorus inactivation, aeration, and biomanipulation with pike and pike-perch) applied to a strongly eutrophic lake produced a distinct decrease of chlorophyll $a$, phosphorus, and nitrogen concentrations, but water transparency only increased slightly (Rosińska et al. 2017). If measures implemented to improve degraded water bodies are to be successful, they should include comprehensive protection and restoration supported by biomanipulation (Gołdyn et al. 2014, Dunalska et al. 2015). Therefore, thorough analyses using 
considerable quantities of multi-year data and modelling results are needed to evaluate the response patterns of phytoplankton to multiple factors, especially fish-induced environmental changes in shallow temperate lakes. This information can be very helpful in maintaining the proper functioning of lake ecosystems, which includes the functioning and development of lake fisheries that are impeded by many administrative, legal, natural, and socioeconomic factors (Mickiewicz and Wołos 2014). Recently, worldwide fisheries management policy has focused on fish stocking with native/autochthonous species and introducing threatened and endangered species primarily to increase fish abundance or to enhance the restoration of degraded lakes (Welcomme 2016). These same trends have also been identified in Poland (Zakęś et al. 2015).

\section{Lake Warniak timeline}

Lake Warniak is an example of an experimentally biomanipulated natural water body (IBP program, Westlake et al. 1998). This lake has undergone several stages of manipulation with the introduction of fish species with various feeding strategies, varied submerged macrophyte biomass, large fluctuations in phytoplankton and zooplankton biomasses, shifts in domination structure, nutrient enrichment, and fluctuating water quality, which has made it possible to identify several periods (Table 15):

1. The first period (1967-1974) is primarily that of the experimental introduction of benthophagous common carp and a densely overgrown lake bottom with the dominant angiosperms of $C$. demersum and E. canadensis (with a total biomass of up to 930 tons). It included the winter fish kills in February 1970 following which the introduction of primarily herbivorous grass carp started and then, the first step of seston-feeding silver carp and bighead carp introduction. This period was characterized by relatively low phytoplankton and zooplankton biomasses, low primary production and destruction of organic matter in summer (Spodniewska and Hillbricht-Ilkowska 1973,
Zdanowski et al. 1999). Copepods dominated zooplankton with a prevalence of cyclopoids of the genera Mesocyclops, Acanthocyclops, and Cyclops. Phytoplankton was co-dominated by nannoplankton and cyanobacteria. This period was generally characterized by the clear-water state and the high/good ecological status of the shallow meso-eutrophic lake.

2. The second period (1975-1984) included the biomass of grass carp gradually increasing to $140 \mathrm{~kg}$ $\mathrm{ha}^{-1}$ in 1976 (Ciepielewski 1985, Zdanowski et al. 1999). The submerged macrophytes (C. demersum, E. canadensis) which previously overgrew the lake bottom densely disappeared in 1975 . The maximum total phytoplankton biomass was in 1978 because of cyanobacteria of the genera Anabaena (presently Dolichospermum), Gomphosphaeria (presently Woronichinia and Snowella) Aphanizomenon, Microcystis, Oscillatoria (presently Planktolyngbya and Pseudanabaena), which can produce cyanotoxins (microcystins, cylindrospermopsins, anatoxins; Kobos et al. 2013). At the same time, zooplankton biomass reached its maximum because of the large-sized cladocerans Daphnia cucullata Sars, D. longispina O.F Müller, and Eudiaptomus graciloides Lilljeborg (Spodniewska 1975, Węgleńska et al. 1979, Zdanowski et al. 1999). Shifts from low to high primary production (from 8.4 Kcal m${ }^{-2} \mathrm{~d}^{-1}$ in 1967-1974 to $17.9 \mathrm{Kcal} \mathrm{m}^{-2} \mathrm{~d}^{-1}$ in 1975-1984, on average) and destruction of organic matter (from $7.7 \mathrm{Kcal} \mathrm{m}^{-2} \mathrm{~d}^{-1}$ in $1967-1974$ to 15.1 Kcal m${ }^{-2} \mathrm{~d}^{-1}$ in 1975-1984 on average) were then noted in summer (Zdanowski et al. 1999). This period included rapid changes and was characterized by an evident shift in 1975 from a clear-water into a turbid-water state, from high/good to moderate/poor ecological status, and from meso-eutrophy to eutrophy. Such drastic changes in the water quality of Lake Warniak were comparable with those in the very shallow Lake Pogubie Wielkie, known as a type of winter-kill-susceptibile tench-pike, after submerged macrophyte disappearance (Hutorowicz and Zdanowski 1993).

3. The third period (1985-1994) included the highest biomass of seston-feeding silver carp and bighead 
Table 15

Lake Warniak timeline

\begin{tabular}{|c|c|c|c|c|c|c|}
\hline & Periods & Introduction or stocking & Fish pressure & Alternative stable state & Ecological status & Trophic state \\
\hline 1967 & I & $\mathrm{CC}$ & $\mathrm{AF}$ & clear-water & & meso-eutrophy \\
\hline 1968 & & $\mathrm{CC}$ & & & & \\
\hline 1969 & & $\mathrm{CC}$ & & & & \\
\hline 1970 & & $\mathrm{CC}+\mathrm{GC}+\mathrm{SC}+\mathrm{BC}$ & & & & \\
\hline 1971 & & $\mathrm{GC}$ & & & & \\
\hline 1972 & & - & & & n.d. & \\
\hline 1973 & & $\mathrm{GC}+\mathrm{SC}+\mathrm{BC}+\mathrm{CC}$ & & & & \\
\hline 1974 & & $\mathrm{GC}$ & & & & \\
\hline 1975 & II & $\mathrm{GC}+\mathrm{SC}+\mathrm{BC}$ & $\mathrm{AF}+\mathrm{CC}+\mathrm{GC}$ & turbid-water & n.d. & eutrophy \\
\hline 1976 & & $\mathrm{GC}+\mathrm{SC}+\mathrm{BC}+\mathrm{CC}$ & & & & \\
\hline 1977 & & $\mathrm{GC}+\mathrm{CC}$ & & & & \\
\hline 1978 & & $\mathrm{GC}+\mathrm{CC}$ & & & & \\
\hline 1979 & & - & & & n.d. & \\
\hline 1980 & & - & & & & \\
\hline 1981 & & $\mathrm{SC}+\mathrm{BC}+\mathrm{P}+\mathrm{CC}$ & & & & \\
\hline 1982 & & $\mathrm{CC}+\mathrm{P}$ & & & & \\
\hline 1983 & & - & & & n.d. & \\
\hline 1984 & & $\mathrm{SC}+\mathrm{BC}$ & & & & \\
\hline 1985 & III & $\mathrm{SC}+\mathrm{BC}+\mathrm{P}$ & S-FF & turbid-water & & eutrophy \\
\hline 1986 & & - & & & & \\
\hline 1987 & & $\mathrm{P}$ & & & & \\
\hline 1988 & & $\mathrm{CC}$ & & & & \\
\hline 1989 & & $\mathrm{P}$ & & & & \\
\hline 1990 & & $\mathrm{P}$ & & & n.d. & \\
\hline 1991 & & - & & & & \\
\hline 1992 & & - & & & & \\
\hline 1993 & & - & & & & \\
\hline 1994 & & $\mathrm{P}$ & & & & \\
\hline 1995 & IV & $\mathrm{P}$ & $\mathrm{AF}+\mathrm{S}-\mathrm{FF}$ & clear-water & & eutrophy \\
\hline 1996 & & $\mathrm{P}$ & & & & \\
\hline 1997 & & $\mathrm{P}$ & & & & \\
\hline 1998 & & $\mathrm{P}$ & & & & \\
\hline 1999 & & - & & & n.d. & \\
\hline 2000 & V & $\mathrm{P}$ & $\mathrm{AF}$ & clear-water & & meso-eutrophy \\
\hline 2001 & & $\mathrm{P}$ & & & & \\
\hline 2002 & & $\mathrm{P}+\mathrm{WC}$ & & & & \\
\hline 2003 & & $\mathrm{P}$ & & & & \\
\hline 2004 & & $\mathrm{P}$ & & & & \\
\hline 2005 & VI & $\mathrm{P}+\mathrm{EE}$ & $\mathrm{AF}$ & turbid-water & & eutrophy \\
\hline 2006 & & $\mathrm{EE}$ & & & & \\
\hline 2007 & & - & & & & \\
\hline 2008 & & $\mathrm{P}+\mathrm{WC}$ & & & & \\
\hline 2009 & & $\mathrm{P}+\mathrm{EE}$ & & & & \\
\hline 2010 & & $\mathrm{P}+\mathrm{WC}$ & & & & \\
\hline 2011 & & $\mathrm{P}$ & & & & \\
\hline 2012 & & $\mathrm{P}$ & & & & \\
\hline 2013 & & $\mathrm{P}$ & & & & \\
\hline 2014 & & $\mathrm{P}$ & & & & \\
\hline
\end{tabular}

CC - common carp, GC - grass carp, SC - sliver carp, BC - bighead carp, P - pike, WC - wels catfish, EE - European eel, AF autochthonous fish, S-FF - seston-feeding fish, - means no introduction or stocking, ecological status: high (blue), good (green), moderate (yellow) and poor (orange), n.d. - no data 
carp in 1992, winter fish kills in 1985 and 1987, and the sporadic introduction of common carp, pike, and European eel, among other species. Significant decreases occurred in phytoplankton biomass, including in that of cyanobacteria, and nannoplanktonic algae dominated. Summer primary production and destruction of organic matter (both $14.2 \mathrm{Kcal} \mathrm{m}^{-2} \mathrm{~d}^{-1}$, on average) were lower than in 1975-1984 (Zdanowski et al. 1999). Significant changes were also noted in zooplankton that included low biomass and the domination of small-sized rotifers of the genera Keratella, Polyarthra, Brachionus, and Trichocerca (Zdanowski et al. 1999, Tunowski 2006, 2009). After their re-introduction through human intervention, submerged macrophytes began to re-colonize in 1993 (Hutorowicz and Dziedzic 2008). Water quality during this period was characterized by a turbid-water state and the good/moderate/poor ecological status of the eutrophic shallow lake.

4. The fourth period (1995-1999) included intense fish exploitation of primarily herbivorous and seston-feeding fish species in 1995 and 1997 and winter fish kills in 1996 that reduced this fish pressure, but the role of autochthonous fish became more important. Submerged macrophytes overgrew the lake bottom densely with a total biomass of up to 550 tons (Zdanowski et al. 1999), and the dominant charophytes were Chara globularis and C. rudis (Hutorowicz and Dziedzic 2008). The maximum summer biomass of phytoplankton dominated by dinoflagellates (Peridinium) and cryptophytes (Cryptomonas) decreased considerably. The summer primary production and destruction of organic matter also dropped to a similar average of $7.7 \mathrm{Kcal} \mathrm{m}^{-2} \mathrm{~d}^{-1}$, and these values were comparable with data from 1967-1974 (Zdanowski et al. 1999). The biomass of rotifer-dominated zooplankton (primarily Asplanchna priodonta Gosse) was also very low (Zdanowski et al. 1999). This period was characterized by a shift from a turbid-water into a clear-water state, and from the moderate (1995) to the high (1997-1998) ecological status of the eutrophic shallow lake.
5. The fifth period (2000-2004) after the removal of experimentally introduced fish included pilot stocking with autochthonous predatory fish, primarily pike and just wels catfish in 2002. Total fish and pike catches peaked in 2001 (Zakęś et al. 2015). Dense charophytes with maximum growth in 2002 (Bałdyga 2008) and the relatively low phytoplankton biomass dominated by cryptophytes induced a clear-water state and a high/good ecological status, which together contributed to the meso-eutrophic conditions of the lake.

6. The sixth period (2005-2014) included the highest fish catches in 2005, because of the high share of non-predatory small fish and the lack of catches in 2007-2009 and 2012 (Zakęś et al. 2015). No winter fish kills were noted, but good oxygen conditions were observed throughout the growth seasons from as early as 2000 and also in the winter of 2011-2014 (this continues to the present) (Napiórkowska-Krzebietke et al. 2012, Zakęś et al. 2015, Kalinowska et al. 2017). Charophytes almost disappeared from the lake in 2005, and only residual phytocoenoses of submerged macrophytes with $C$. demersum occurred (Bałdyga 2008). Currently, only single individuals are observed very rarely growing on the lake bottom; these are primarily of the genus Potamogeton (B. Zdanowski - personal communication). This period was characterized by phytoplankton with a maximal biomass that was approximately four-fold higher than in the previous period and a phytoplankton structure that shifted from one dominated by cyanobacteria to one dominated by dinoflagellates and from one dominated by cryptophytes to one dominated by diatoms. The zooplankton was represented by the large cladoceran Daphnia and copepod Cyclops and also small rotifers of the genera Keratella, Polyarthra, Brachionus, Filinia, Kellicottia, and Trichocerca. Generally, this period was characterized by a turbid-water state, good/moderate/poor ecological status, and the eutrophic state of the shallow lake. 


\section{Phytoplankton growth patterns and shifts in dominance}

In 2000-2004, the two similar biomass peaks in the seasonal growth pattern of phytoplankton were consistent with the original Plankton Ecology Group (PEG) Model typical of oligotrophic (Sommer et al. 1986) or moderately nutrient-rich (Oleksowicz 1988) stratified waters. The main representatives of the phytoplankton were primarily the large and small cryptophytes Cryptomonas curvata, C. marssonii, $C$. erosa, Plagioselmis nannoplanctica, and Rhodomonas lens, which are typical of various habitats and are able to occur in almost all lentic ecosystems with low grazing pressure $(\mathrm{Y})$, or they are typical of shallow environments that range from meso-eutrophic to eutrophic (X2) (Reynolds et al. 2002, Padisák et al. 2009). This period could be classified as a clear-water state because of the relatively low phytoplankton biomass, the constant domination of the same cryptophytes throughout the growth season, good water transparency, and the stage dominated by Charales in shallow meso-eutrophic Lake Warniak. Similar findings are reported, inter alia, for a shallow lake dominated by Chara in Estonia (Tõnno et al. 2003).

Seasonal phytoplankton growth in the second period (2005-2014) resembled patterns of one high biomass peak that occurred in the middle of summer with the domination of cyanobacteria. Such seasonal development is somewhat similar to the PEG Model that is typical of eutrophic (Sommer et al. 1986) or nutrient-rich (Oleksowicz 1988) stratified waters and that occurs in productive fishponds (Napiórkowska-Krzebietke and Hutorowicz 2012). The domination structure varied significantly from period to period, but it was possible to distinguish four stages of generally dominant $(\geq 50 \%)$ groups in the phytoplankton: those dominated by cyanobacteria in 2005-2008; by dinoflagellates in 2009-2011; by cryptophytes in 2012; by diatoms in 2013-2014. In particular, shifts in the functional traits of phytoplankton assemblages followed the coda $\mathrm{K} \rightarrow \mathrm{L}_{\mathrm{O}}+\mathrm{Y} \rightarrow \mathrm{Y}+\mathrm{L}_{\mathrm{O}}+\mathrm{F}+\mathrm{X} 2 \rightarrow \mathrm{D}+\mathrm{K}+\mathrm{P}+\mathrm{A}$. Thus, their representatives usually occurred in higher abundance in the shallow, nutrient-rich water column, i.e., coda K, Y, LO, X2, D, P, or in clear, deep, well-mixed, nutrient-poor lakes, i.e., coda A, F (Reynolds et al. 2002, Padisák et al. 2009). The whole period of 2005-2014 was determined to be a turbid-water state because of the relatively high phytoplankton biomass, the highly varied seasonal phytoplankton domination structure, the lower water transparency, and the disappearance of Charales. The exception could be the structure of the phytoplankton assemblages in 2012, which was similar to that of 2001, and the lowest phytoplankton biomass for the 2005-2014 period, which suggested a short-term shift back toward the phytoplankton taxonomic structure that occurred when there was a clear-water state. Cluster analysis based on taxon biomass indicated the same tendency. This phenomenon could be confirmation of the possibility of a transition from one state to another without a significant change in nutrient enrichment (Scheffer et al. 1993). However, the findings of Wang et al. (2016) suggest there are higher contents of mobile C and $\mathrm{P}$ after macrophytes disappear, which can enhance phytoplankton growth.

Compared with historical data (Spodniewska and Hilbricht-Ilkowska 1973, Spodniewska 1975, Węgleńska et al. 1979), the seasonal phytoplankton growth in 2000-2004 was the most similar to that of 1968 when common carp was introduced, whereas in 2005-2014 it was the most similar to that of 1967 at the beginning of the experiments and to 1973 when the biomass of common carp and grass carp began to grow rapidly. The maximum phytoplankton biomass of $19.5 \mathrm{mg} \mathrm{dm}^{-3}$ in 1967-1974 (Spodniewska and Hillbricht-Ilkowska 1973, Węgleńska et al. 1979) was similar to the maximum for 2005-2014, when autochthonous fish dominated the ichthyofauna with relatively low cyprinid pressure. In 1976-1993, when the pressure of introduced cyprinids, initially of common carp and grass carp and later of silver carp and bighead carp, was high, phytoplankton biomass increased to as high as 50.0 $\mathrm{mg} \mathrm{dm}^{-3}$ (Krzywosz 1999, Zdanowski et al. 1999). After the pressure of introduced fish was reduced 
significantly, phytoplankton biomass decreased considerably.

The multiple approaches presented for describing phytoplankton response to fish-induced environmental changes can facilitate predicting probable changes throughout shallow lake ecosystems followed by changes in certain quality elements. Historical data in conjunction with current data were also used to investigate how different variables can affect each other.

\section{Hypothesis 1. Elevated temperature and nutrient enrichment enhance phytoplankton growth and shifts in structure toward cyanobacteria domination}

In phytoplankton-temperature relations, a significantly positive correlation indicated the distinct enhancement of total biomass throughout the growth seasons in 2000-2014 along with an increase of water temperatures, which was directly associated with climatic/meteorological seasonal changes. Water temperatures had a similar positive effect on the biomass of particular groups such as cyanobacteria, planktonic charophytes, chlorophytes, euglenophytes, and dinoflagellates. However, the phytoplankton-temperature dependence was not as clearly evident in multi-year (1967-2014) comparisons. The thermal regime of the surveyed lake is dependent on the micro-climate that prevails in the mesoregion of the Masurian Lake District in northeastern Poland, which is in the temperate zone, and long-term variations in climatic factors, primarily atmospheric air temperature, precipitation, and wind. Domination shifts toward increased cyanobacteria biomass were recorded when the average annual air temperature was higher by approximately $2^{\circ} \mathrm{C}$ than the multi-year average $\left(6.9^{\circ} \mathrm{C}\right)$ and in both dry and wet years (2005-2008), which seems to confirm the theory described by Elliot (2012), Jeppesen et al. (2014), and Rigosi et al. (2014). On the other hand, the dominant cyanobacteria were primarily picoplanktonic colonial Aphanocapsa, which contributed the most to the maximal phytoplankton biomasses in the warmest years of 2007 and 2008 and in one of the driest years in 2005. Thus, these results are in accordance with the findings of Wood et al. (2017) that indicate that climate warming, especially when it coincides with extended droughts favor picocyanobacteria. The very good mixing conditions throughout the water column meant that homothermia was noted most often in the shallow Lake Warniak. Thus, the water column was also well-oxygenated with periods of supersaturation during all the growth seasons of 2000-2010, except for the early spring in 2010, when hypoxia $(<50 \%$ oxygenation) occurred in the near-bottom layers (Napiórkowska-Krzebietke et al. 2012). Good oxygen conditions for fish survival were noted in 2000-2014 and even later, and these also included periods of ice-cover (Zakęś et al. 2015, Kalinowska et al. 2017). Compared with earlier studies, oxygen deficits were recorded during periods of ice cover in the 1950 s, then in the 1970 s with winter fish kills, as well as several times in the 1980s and 1990s (Zachwieja 1972, Karpiński 1994, Zdanowski et al. 1999). With regard to the II degree of staticity in Lake Warniak (Napiórkowska-Krzebietke et al. 2012), it was possible that production and decomposition occurred in the same water layer.

Several studies have been undertaken to quantify the key role of nutrients, primarily $\mathrm{TP}$ and $\mathrm{TN}$, as drivers of changes in phytoplankton growth, structure, and species domination (e.g. Smith et al. 2016, Søndergaard et al. 2017). In Lake Warniak, the average seasonal TP content was the highest in 1975-1984 when the submerged macrophytes disappeared, which is consistent with the findings of Wang et al. (2016). Multi-year comparisons from 1967-1998 (historical data) and 2000-2014 (current data), indicate that the mean concentrations of TP were very similar. However, there were significant positive relationships among phytoplankton features and phosphates and total phosphorus. The highest summer biomass of cyanobacteria was noted in the 1975-1984 period with the highest TP concentrations (Zdanowski et al. 1999). In summer, precipitation could have played an additional important role in $\mathrm{P}$ enrichment. According to Kowalczewski and 
Rybak (1981), the atmospheric deposition of phosphorus in Lake Warniak was calculated at $20 \mu \mathrm{mol} P$ $\mathrm{m}^{-2} \mathrm{~d}^{-1}$. In 2000-2014, total nitrogen concentrations were slightly lower than in 1967-1998, and they did not play any significant role in phytoplankton growth. However, a distinct positive correlation was noted between ammonium nitrogen and total phytoplankton biomass. To conclude, hypothesis 1 was confirmed in the case of phosphorus enrichment concerning the entire 1967-2014 period; however, elevated temperatures also contributed to phytoplankton changes, but only in the 2000-2014 period.

\section{Hypothesis 2: Competition and selective grazing limit phytoplankton growth and biodiversity}

Submerged and emerged macrophytes are key stabilizing factors in nutrient exchange from the immediate catchment area and bottom sediments in shallow lakes. Furthermore, competition and allelopathy usually play very important roles in the relationships among submerged macrophytes and phytoplankton (e.g., Lürling et al. 2006), and this includes the presence of allelopathically active macrophytes, strain-specific phytoplankton taxa, and their local adaptation to allelochemicals (Eigemann 2013). Therefore, one of two contrasting alternative stable states can occur; the clear-water state with the dominance of submerged macrophytes or the turbid-water state with the dominance of phytoplankton conditioned by various factors (Scheffer et al. 1993, Scheffer and van Nes 2007). Accordingly, the 2000-2004 period in Lake Warniak was most similar to the stable clear-water state with the dominance of submerged macrophytes, whereas the 2005-2014 period was similar to that of a turbid-water state with the dominance of phytoplankton in which only residual phytocoenoses or single specimens of submerged macrophytes were noted in the inshore zone of the lake (K. Stawecki and B. Zdanowski - personal communication). The first period with Charales domination was characterized by lower species richness than the period with phytoplankton domination. This shift to a turbid-water state could have been enhanced in the warmer years (Elliot 2012, Bergkemper and Weisse 2017) that were recorded, especially in 2007-2008 and 2014. Other factors triggering this shift could also have been predator-prey cycles or a complex of internally and externally generated fluctuations (Naselli-Flores et al. 2003, Salmaso 2003, Scheffer and Carpenter 2003).

Significant negative phytoplankton-macrophyte relationships were confirmed in comparisons of ecological status assessments performed with the phytoplankton based multimetric PMPL MOD (Napiórkowska-Krzebietke 2015) for "Total Biomass" and "Cyanobacteria Biomass" and for periods with and without submerged macrophytes. The PMPL $\mathrm{MOD}_{\mathrm{D}}$ values indicated high/good status in 1967-1974 and 1996-2004, when the lake was in a clear-water state dominated by angiosperm submerged macrophytes (C. demersum and E. canadensis) or Charales ( $C$. globularis, $C$. rudis). The maximal biomasses of submerged macrophytes were also comparable in both periods analysed (Zdanowski et al. 1999, Bałdyga 2008). In 1976-1995 and 2005-2014, the PMPL MOD values indicated the deterioration of water quality to poor ecological status when distinct increases were noted mostly of cyanobacteria in the phytoplankton biomass, and chlorophyll $a$ content increased as the submerged macrophytes disappeared. The maximal values of total phytoplankton biomass recorded in 2005-2014 and 1976-1995 were characteristic of a phytoplankton bloom intensity of $8-21 \mathrm{mg} \mathrm{dm}^{-3}$ and 21-100 $\mathrm{mg} \mathrm{dm}^{-3}$, which were characteristic of the moderate and poor ecological status of the lake, respectively (Napiórkowska-Krzebietke and Dunalska 2015). Cyanobacteria, represented mostly by the chroococaleans Aphanocapsa incerta and Microcystis aeruginosa and nostocaleans of the genus Dolichospermum (previously Anabaena) co-dominated in the summer phytoplankton assemblages. Most of these species are well-known as toxic or potentially toxic (Kobos et al. 2013). Some symptoms of changes toward a turbid-water state in Lake Warniak were visible. According to Søndergaard et al. (2017), macrophyte loss can be exacerbated by the abundant 
growth of filamentous algae in winter and by phytoplankton and periphyton in summer, which is consistent since expected allelopathy trends increase with climate warming (Jeppessen et al. 2014).

The studies on zooplankton in Lake Warniak in the summers of 1967-1998 proved that there were significant changes in its biomass, numbers, and composition (Zdanowski et al. 1999, Tunowski 2006, 2008). Starting from the co-domination of cladocerans, copepods, and rotifers in 1967, subsequent zooplankton dominants were as follows: cladocerans (1968, 1978); copepods (1970-1974); rotifers (1976, 1984-1997); rotifers and copepods (1998). Similar high variations were also noted in phytoplankton biomass and structure, which were exhibited in shifts from cyanobacteria and nannoplankton co-domination through nannoplankton domination to cyanobacteria domination, including well-known toxic or potentially toxic species of the genera Microcystis and Anabaena (currently Dolichospermum) (Spodniewska and Hillbricht-Ilkowska 1973, Węgleńska et al. 1979, Krzywosz 1999, Zdanowski et al. 1999). The highest zooplankton and phytoplankton biomasses were recorded in the 1975-1984 period, with the maximum in 1978. These were accompanied by the high co-pressure of autochthonous fish and introduced common carp and grass carp. There was a significant linear relationship between phytoplankton and zooplankton in 1967-1998. The functioning of the planktonic food web, including the short grazing chain, can be described by trophic efficiency. The highest trophic efficiency was in the 1967-1974 period in parallel with low phytoplankton biomass, the high share of large filtrators of Cladocera and Copepoda (Daphnia cucullata, D. longispina and Eudiaptomus graciloides), good water quality, a clear-water state dominated by macrophytes, and the domination of autochthonous fish in the ichthyofauna, all of which indicated that the functioning of the ecosystem was stable. The lowest trophic efficiency was recorded under the following conditions: high cyanobacteria dominated phytoplankton biomass; low rotifer dominated zooplankton biomass; a turbid-water state; the highest pressure of seston-feeding fish in 1985-1994. This low trophic efficiency was also noted in the next period of 1995-1998 during clear-water state. During this period, the zooplankton comprised small-sized species of the genera Keratella, Polyarthra, Brachionus, and Trichocerca, and their pressure on phytoplankton was very limited. Similar findings that indicate the reduced impact of zooplankton characterized by the low abundance of large cladocerans on phytoplankton were observed in the hypertrophic Lake Uzarzewskie (Dondajewska et al. 2017). Reduced zooplankton grazing pressure on phytoplankton can also be exacerbated by climate warming when a higher share of small-sized zooplankton taxa is expected (Meerhoff et al. 2007). The next phase in Lake Warniak that was dominated by Chara, when the biomass of "edible" phytoplankton of nannoplankton origin was approximately $50 \%$ of the total biomass, was similar to that in the shallow eutrophic Lake Prossa in Estonia (Tõnno et al. 2003) where zooplankton pressure was high. In Lake Warniak, both zooplankton and phytoplankton biomasses were low at this time, which indicated moderate trophic efficiency. The next changes toward higher planktonic biomass (after 2004) were characterized by rather low trophic efficiency because of the high share of either cyanobacteria or large dinoflagellates. While cyanobacteria cannot always limit zooplankton abundance, according to Jia et al. (2017), large-sized cladoceran species can even be positively correlated with cyanobacteria.

It was possible to calculate the biodiversity indices only for the current period of 2000-2014 to determine the effect of competition and selective grazing on phytoplankton biodiversity. S-WI, evenness, and species richness were higher in 2005-2014 with the turbid-water state and even moderate/poor ecological status compared to 2000-2004 with a clear-water state dominated by Chara and a high/good ecological status. To conclude, hypothesis 2 was confirmed with regard to both competition between macrophytes and phytoplankton and the short grazing chain during the stage when autochthonous fish dominated the ichthyofauna, which in turn, significantly limited phytoplankton biomass and biodiversity. 


\section{Hypothesis 3: Key drivers (factors/species) affect phytoplankton-related changes throughout the ecosystem}

\section{Nutrients}

The functional traits of dominant taxa as a response to nutrient-related environmental changes confirmed the high fluctuation and the lack of stability in phytoplankton assemblages where the main representatives of coda Y + X2 + X1 + $\mathrm{L}_{\mathrm{O}}(2000-2004) \rightarrow$ $\mathrm{K}(2005-2008) \rightarrow \mathrm{L}_{\mathrm{O}}+\mathrm{Y}(2009-2011) \rightarrow \mathrm{Y}+\mathrm{L}_{\mathrm{O}}+\mathrm{F}$ $+\mathrm{X} 2$ (2012) $\rightarrow \mathrm{D}+\mathrm{K}+\mathrm{P}+\mathrm{A}(2013-2014)$ are typical of both nutrient-poor and nutrient-rich lakes (Reynolds et al. 2002, Padisák et al. 2009). The role of phosphorus was important for phytoplankton growth manifested primarily by significant positive correlations and also by changes in the values of the eco-sensitivity factor, which describes taxa sensitivity along with the eutrophication gradient expressed as TP concentration (Phillips et al. 2013, Napiórkowska-Krzebietke et al. 2017). The highest values of the eco-sensitivity factor recorded in 2005-2008 revealed the distinct domination of the tolerant taxa $A$. incerta and $M$. aeruginosa in the phytoplankton, which occurred simultaneously with higher TP. It coincides with the bottom-up control by food availability that only phosphorus plays an important role and that of nitrogen was diminished.

\section{Submerged macrophytes}

The changes in macrophyte communities and the accompanying environmental changes primarily due to the introduction of herbivorous grass carp in 1970 were noted on a large scale, and they were of a high amplitude. Their durability was also variable and unstable. Regardless of the long-term relations between phytoplankton and submerged macrophytes, they were negative and statistically significant. The phase when macrophytes were dominated primarily by $C$. demersum and E. canadensis and a clear-water state in 1967-1974 (Krzywosz 1997, Zdanowski et al. 1999) was characterized by relatively small phytoplankton biomass and low chlorophyll $a$ contents and good water transparency. The water quality in the lake in this period was at least of a good (high plus good) ecological status based on PMPLMOD, which corresponded to the I-II water quality class. The disappearance of submerged macrophytes for 17 years (1975-1992) was caused mainly by high grass carp pressure and was associated with significantly increased phytoplankton biomass and the phase dominated by phytoplankton in the turbid-water state.

The Chara re-domination, after its first occurrence in 1958-1959 (Bernatowicz 1969, Dąmbska 1969, Hutorowicz and Dziedzic 2008) in the submerged macrophyte communities evidently stabilized the clear-water state and the high ecological status in the meso-eutrophic Lake Warniak in 1997-2004. These findings are similar to those of Tónno et al. (2003) in a Chara lake. The positive results of macrophyte recovery and improvement of light conditions following biomanipulation as a restoration tool were confirmed by Yu et al. (2016) and Rosińska et al. (2017). After the disappearance of Chara in 2004, the role of $C$. demersum in the macrophyte community increased (Bałdyga 2008), but this species can also occur under enhanced eutrophication conditions. Such changes, including the rapid loss of Chara and the gradual loss of other macrophytes were accompanied by decreasing water quality exemplified by a decrease of SDD, an increase of chlorophyll $a$ content and phytoplankton biomass, and the TLI-based eutrophic state in 2005 that persisted until 2014. Generally, charophytes are very sensitive to decreases in water transparency and increases in trophic levels (e.g., Krupska et al. 2012). Thus, Chara species played a significant role in maintaining a clear-water state in Lake Warniak in 1997-2004.

\section{Fish fauna}

Some multiple metrics of fish demonstrated an increasing trend along with autotrophic activity and a variety of fishery activities (Deines et al. 2015, Ritterbusch et al. 2017). However, a certain deviation from positive relationships can be expected because of the regional climate. Some significant correlations 
were noted in the positive role phytoplankton played on fish production (Napiórkowska-Krzebietke et al. 2016). For example, in Egypt, the enhancement of primary and secondary production (primarily of phytoplankton and zooplankton) as natural fish food is one of the potential strategies for increasing fish production (Hussian et al. 2015). In the late 1960s, a study on food resources and fish stocking in Lake Warniak confirmed that the basic food for pike was usually roach and perch (Ciepielewski 1973). Common carp, bream, and tench fed on bottom fauna, and the fauna fed on the plants; crucian carp fed on zooplankton, and roach fed on macrophytes (95\%) and algae (4\%) (Prejs 1973). Some literature reports suggest that phytoplankton are important food resources for fish larvae or even for adults like silver carp and bighead carp (Conover et al. 2007, Sauvanet et al. 2013, Anderson et al. 2017, Napiórkowska-Krzebietke 2017 and references therein); however, phytoplankton may not fully support proper growth in larger individuals (Malzahn et al. 2007). Temporary oxygen deficits near the bottom sediments in 1967-1974 (Zachwieja 1973, Węgleńska et al. 1979) and then sporadically (Zdanowski et al. 1999) and winter fish kills in 1970, 1985, 1987, and 1996 contributed to serious reductions in both autochthonous and allochthonous fish biomasses in Lake Warniak. These uncontrolled events can have a cascading effect on the functioning of food webs in lakes (Balayla et al. 2010, Sayer et al. 2016). Additionally, the intense fish catches before 2000 that exceeded $150 \mathrm{~kg} \mathrm{ha}^{-1}$ in 1995 and 1997 , and those after 2000 of approximately $50 \mathrm{~kg} \mathrm{ha}^{-1}$ in 2001 and 2005 (Zdanowski et al. 1999, Zakęś et al. 2015) lowered fish biomass considerably.

Grass carp was first introduced outside its native range of occurrence after 1945 (Kirkağaç 2011), and it was first introduced in Poland in 1964 (Gierałtowski 1967). These were done for both aquatic management and aquaculture purposes (Opuszyński and Shireman 1995). Earlier studies indicated that grass carp introduction significantly impacted aquatic environments, including both physicochemical and biological water quality parameters (e.g., Rose 1972, Lembi et al. 1978, Krzywosz et al. 1980, Shireman et al. 1985, Krzywosz 1997, Kirkağaç and Demir 2006, Krupska et al. 2012). In the 1970s, grass carp was the key species that indirectly, but significantly, affected phytoplankton abundance and structure in Lake Warniak (Spodniewska 1975, Węgleńska et al. 1979). Then, two other cyprinids, silver carp and bighead carp, took over this role by reducing the top-down control by zooplankton on phytoplankton, and, contrary to assumptions, they enhanced phytoplankton biomass. This is consistent with the findings of Opuszyński (1978, 1987), Radke and Kahl (2002), and Zhou et al. (2011) that biomanipulation with silver carp and bighead carp can be ineffective in limiting the phytoplankton biomass and cyanobacteria cannot be successfully digested. Furthermore, these two cyprinid species are known to be difficult fish to catch, and they are not attractive to anglers; thus, their biomasses are hard to control. The successful removal of herbivorous and seston-feeding fish species from Lake Warniak was only possible by intense fish catches and winter fish kills. Similar to the results of the meta-data-analysis on 128 biomanipulations in 123 lakes by Bernes et al. (2015), average Secchi disk depth significantly increased and average chlorophyll $a$ concentrations significantly decreased in Lake Warniak. These positive effects persisted for as long as seven years after the successful removal of the herbivorous and seston-feeding fish, but they were also supported by the submerged macrophyte re-colonization.

After the period of the more or less intense introduction of herbivorous and seston-feeding fish species and irregular winter fish kills, pilot stocking with an autochthonous population of predatory fish was initiated in Lake Warniak. Throughout the 2000-2014 period, Lake Warniak was regularly stocked with pike, whereas with wels catfish, and European eel only for three years. The same fish species and also pikeperch were used as a biomanipulation tool to improve water quality in Maltański Reservoir (Gołdyn et al. 2014, Kozak et al. 2015). Furthermore, pike is the most popular, well-known fish species used to maintain proper ichthyofauna structure and appropriate food web equilibrium, and it is important worldwide in biomanipulations applied to 
restore degraded water reservoirs (e.g., Jeppesen et al. 2012, Gołdyn et al. 2014) by significantly reducing planktivorous and planktophagous fish (Skov et al. 2003, Skov and Nilsson 2007, Bernes et al. 2015). Presumably, this management strategy should be helpful in facilitating clear-water state by enhanced grazing pressure on phytoplankton. In Lake Warniak, a clear-water state and high/good ecological status persisted only from 1997 to 2004, which was the period directly after the removal of herbivorous and seston-feeding fish in the first years of regular pilot stocking with predatory pike when submerged macrophyte biomass was high. A shift toward deteriorating water quality after 2004 did not coincide with any further fish stocking, but it is important that the share of pike in total monitoring catches declined. This, in turn, appears to confirm the general decreasing tendency in the share of pike along with the deteriorating environmental conditions noted in Polish polymictic lakes during the WFD intercalibartion on Lake Fish Index systems (Ritterbusch et al. 2017). Furthermore, shares of perch, tench, and large roach also decreased, whereas those of pikeperch and crucian carp increased as the ecological status of polymictic lakes worsened.

Multi-year relationships between phytoplankton and fish were significant in Lake Warniak. They were negatively correlated with phytoplankton for autochthonous fish. Thus, top-down control by the grazing pressure of the large filtrators Cladocera and Copepoda and fish was important in periods when autochthonous fish dominated the ichthyofauna of Lake Warniak. On the other hand, positive phytoplankton-fish relationships were noted for all introduced fish, but also separately for two seston-feeding fish species and grass carp. Such positive inter-correlated quantitative dependencies confirm a low or even the lack of their importance for top-down control in this lake.

Furthermore, similarly to the Maltański Reservoir that was subjected to biomanipulation mainly with pike (Gołdyn et al. 2014), colonial cyanobacterial blooms also occurred in Lake Warniak in 2005-2008.
The biomass of the dinoflagellate Peridinium in 2009-2011 increased considerably. This was similar to the results of Ofir et al. (2017) and suggested that biomanipulation could fail to improve water quality or to significantly decrease phytoplankton biomass. Conversely, an increase in Peridinium biomass and water deterioration were both noted. Thus, after 2004, rather symptoms of ichthyoeutrophication, similar to those in 1976-1994, were detected again in Lake Warniak (Opuszyński 1987) with high pressure from grass carp, silver carp, and bighead carp than improved water quality. These findings provide important insight for future lake management, which should focus on the overall food web structure and effective energy flows; in short, an ecosystem based approach should be applied. A mass balance model that describes food web functioning against the background of ecosystem properties was elaborated for a shallow macrophytic lake (Guo et al. 2013). The results suggest that the stocking should be directed at increasing predatory diversity using piscivorous and omnivorous species, and, furthermore, at developing eco-friendly fisheries together with the utilization and protection of submerged plants. To conclude, hypothesis 3 was confirmed with regard to phosphorus, Chara species, large filtrators of Cladocera and Copepoda, and autochthonous fish species. These are the key drivers that affect changes associated with phytoplankton throughout the shallow lake ecosystems.

The case study of the shallow pond-type Lake Warniak is a good example of natural process of lake extinction accelerated by human activities associated with unsuccessful biomanipulation measures, including experimental stocking with the cyprinids common carp, grass carp, silver carp, and bighead carp. Furthermore, fisheries management can either decelerate, if appropriate, or accelerate, if inappropriate, this natural process that is also accompanied by significant changes related to the environment, such as shifts in phytoplankton biomass and structure, slower or faster rates of helophyte and floating-leaved plant spread, and the colonization or disappearance of submerged macrophytes. 


\section{Summary and conclusions}

Historically, the shallow pond-type Lake Warniak was subjected to restoration measures including the introduction of herbivorous grass carp and seston-feeding silver carp and bighead carp to control submerged macrophytes and phytoplankton. The state of the lake shifted from a clear-water (1967-1974) to a turbid-water state (1975-1995) as the result of this biomanipulation. Then, after reducing fish pressure, through the significant removal of introduced fish and submerged macrophyte re-colonization, there was another shift from a turbid-water to a clear-water state that persisted until 2004. Then, another turbid-water state occurred during the period when there was significant Charales decline and substantial reductions in submerged macrophyte biomass.

In comparison to historical data from the 1967-1998 period when non-native fish were experimentally introduced into the lake, the current data from all the growth seasons during the 15-year study (2000-2014, with predatory fish pilot stocking) indicate that long-term changes occurred in the phytoplankton. In 2000-2014, the phytoplankton assemblages, which included representatives that usually occur in both nutrient-rich and nutrient-poor lakes, were characterized by changes from period to period as follows:

a) cryptophyte dominated (2000-2004) and functional $\mathrm{Y}+\mathrm{X} 2+\mathrm{X} 1+\mathrm{L}_{\mathrm{O}}$ assemblages with a maximum biomass of $5.0 \mathrm{mg} \mathrm{dm}^{-3}$;

b) cyanobacteria dominated (2005-2008) and functional $\mathrm{K}$ assemblages with a maximum biomass of $20.0 \mathrm{mg} \mathrm{dm}^{-3}$;

c) dinoflagellate dominated (2009-2011) and functional $\mathrm{L}_{\mathrm{O}}+\mathrm{Y}$ assemblages with a maximum biomass of $16.0 \mathrm{mg} \mathrm{dm}^{-3}$;

d) cryptophyte dominated (2012) and functional Y + $\mathrm{L}_{\mathrm{O}}+\mathrm{F}+\mathrm{X} 2$ assemblages with a maximum biomass of $9.0 \mathrm{mg} \mathrm{dm}^{-3}$;

e) diatom dominated (2013-2014) and functional D $+\mathrm{K}+\mathrm{P}+\mathrm{A}$ assemblages with a maximum biomass of $15.0 \mathrm{mg} \mathrm{dm}^{-3}$.
Rapid changes in the biomass and structural components of phytoplankton assemblages after the disappearance of Charales in 2004 were characterized by:

a) a lack of stability or distinct tendencies in biomass size until 2014;

b) successive, high-amplitude, impermanent changes in phytoplankton structure approximately every two or three years or even from year to year;

c) high shares of cyanobacteria in summer phytoplankton indicating shifts toward cyanobacteria domination in 2005-2008 and then their subsequent decline;

d) high fluctuation in domination structures from period to period;

e) increases in total biomass and species richness;

f) a return to typical phytoplankton-dominated state after the decline of macrophytes that were typical of a turbid-water state.

The multi-year (1967-2014) analysis of phytoplankton responses to fish-induced environmental changes in a temperate shallow lake identified a strict dependency. In verifying all of the study hypotheses, it was possible to draw more conclusions.

1. The total phytoplankton biomass increased with increasing water temperatures throughout all of the seasons of the studied period (2000-2014). A phytoplankton domination shift toward cyanobacteria was recorded in warmer years when the average annual air temperature was higher by approximately $2^{\circ} \mathrm{C}$ than the $1953-1999$ mean of $6.9^{\circ} \mathrm{C}$. The phytoplankton-temperature dependence was not as evident in multi-year (1967-2014) comparisons.

2. Only phosphorus played an important role in bottom-up control of food availability. The role of nitrogen was limited considerably.

3. The phytoplankton-macrophyte (primarily submerged) dependence can suggest the occurrence of strong competition in Lake Warniak. C. demersum and E. canadensis in 1967-1974 and Chara species in 1997-2004 played key roles in maintaining a macrophyte dominated clear-water state with at least a good ecological status and meso-eutrophic conditions in Lake Warniak. 
4. The higher biodiversity indices in 2005-2014 with a turbid-water state, moderate/poor ecological status, and eutrophy than in 2000-2004 with the Chara dominated clear-water state, high/good ecological status, and meso-eutrophy suggest that submerged macrophyte competition together with a lower trophic state can accelerate the loss of biodiversity.

5. Four distinct periods were identified-two with macrophyte dominated clear-water state, low phytoplankton biomass, and high shares of nannoplankton (1967-1974 and 1995-2004) and two with phytoplankton dominated turbid-water state, macrophyte loss or their residual phytocoenoses or single specimens, and relatively high shares of cyanobacteria (1975-1994 and 2005-2014)-that confirmed the transition from one state to another occurring only with slight changes from meso-eutrophy to eutrophy, but with substantial shifts in fish pressure.

6. A significant positive relationship between phytoplankton and zooplankton, especially in 1967-1998, confirmed the important role of the short grazing chain in top-down control. Furthermore, the highest trophic efficiency in 1967-1974 was concurrent with low phytoplankton biomass, the high share of large cladoceran and copepod filtrators Daphnia cucullata, D. longispina, and Eudiaptomus graciloides, good water quality, macrophyte dominated clear-water state, and the domination of autochthonous fish in the ichthyofauna. In contrast, the lowest trophic efficiency in 1985-1994 was associated with high phytoplankton biomass dominated by cyanobacteria, low zooplankton biomass dominated by rotifers, turbid-water state, and the highest pressure of silver carp and bighead carp.

7. The multi-year significant negative relationships suggest the importance of phytoplankton top-down control exerted by grazing pressure in the periods when autochthonous fish, which also include predatory fish, dominated the lake ichthyofauna. In contrast, positive relationships with all introduced fish and also separately with seston-feeding fish and grass carp suggest their weak influence or even the absence of it on the top-down control of phytoplankton, and periods in which they exerted high pressure were more similar to ichthyoeutrophication than to improved water quality.

8. The recent study period (2000-2014), during which predatory fish pilot stocking with pike was performed, suggests that the role of this fish in the control of phytoplankton growth is important, but only in concert with the domination of Charales and the removal of herbivorous and seston-feeding fish. The unstable phytoplankton growth and structure recorded after the disappearance of Charales in 2004 suggests that any improvement in water quality was only temporary despite continued stocking with pike.

Acknowledgments. The material was collected and analysed primarily as a part of statutory research (S-009) conducted at the Stanisław Sakowicz Inland Fisheries Institute in Olsztyn. I am grateful to Professor Bogusław Zdanowski for his kind help, essential suggestions, and consultations. I wish to thank Professor Bogusław Zdanowski, Professor Łucjan Chybowski, Dr. Bożena Szczepkowska, Konrad Stawecki, Jakub Pyka, Joanna Hutorowicz, Bartosz Czarnecki, Barbara Błocka, and Anna Szostek for providing unpublished data on physicochemical parameters, fish biomass, and meteorological data. I am also grateful to Dr. hab. Elżbieta Zębek for her help in performing CCA analyses.

\section{References}

Abd El Baky H.H., El-Baroty G.S. 2013 - Healthy Benefit of Microalgal Bioactive Substances - J. Aquat. Sci. 1(1): 11-23.

Amaral P.A.P., Coral L.A., Nagel-Hassemer M.E., Belli T.J., Lapolli F.R. 2013 - Association of dissolved air flotation (DAF) with microfiltration for cyanobacterial removal in water supply - Desalin. Water Treat. 51: 1664-1671.

Anderson K.R., Chapman D.C., Wynne T.T., Paukert C.P. 2017 - Assessment of phytoplankton resources suitable for bigheaded carps in Lake Michigan derived from remote sensing and bioenergetics - J. Great Lakes Res. 43(3): 90-99.

Balayla D., Lauridsen T.L., Søndergaard M., Jeppesen E. 2010 - Larger zooplankton in Danish lakes after cold 
winters: are winter fish kills of importance? Hydrobiologia 649: 159-172.

Bałdyga E. 2008 - The dynamics of submerged vegetation in the Lake Warniak - PhD thesis, UWM, Olsztyn, 86 p. (in Polish).

Bergkemper V., Weisse T. 2017 - Phytoplankton response to the summer 2015 heat wave - a case study from prealpine Lake Mondsee, Austria - Inland Waters 7(1): 88-99.

Bernatowicz S. 1969 - Macrophytes in the lake Warniak and their chemical composition - Ekol. Pol. 17: 447-467.

Bernes C., Cartenter S.R., Gårdmark A., Larsson P., Persson L., Skov C., Speed J.D.M., Van Donk E. 2015 - What is the influence of a reduction of planktivorous and benthivorous fish on water quality in temperate eutrophic lakes? A systematic review - Environ. Evid. 4(13): 3-144.

Białokoz W. 1997 - Intensity and effectiveness of feeding by selected fish species - Arch. Pol. Fish. 5: 5-36 (in Polish).

Brentrup J.A., Williamson C.E., Colom-Montero W., Eckert W., de Eyto E., Grossart H-P., Huot Y., Isles P., Knoll L.B., Leach T.H., McBride C.G., Pierson D., Potami F., Read J.S., Rose K.C., Samal N.R., Staehr P.A., Winslow L.A. 2016 - The potential of high-frequency profiling to assess vertical and seasonal patterns of phytoplankton dynamics in lakes: an extension of the Plankton Ecology Group (PEG) model - Inland Waters 6: 565-580.

Burns N.M., Rutherford C.R., Clayton J.S. 1999 - A monitoring and classification system for New Zealand lakes and reservoirs - Lake Reserv. Manage. 14(4): 255-271.

CEN EN 15204, 2006. Water quality - Guidance standard for the routine analysis of phytoplankton abundance and composition using inverted microscopy (Utermöhl technique).

Ciepielewski W. 1973 - Experimentally increased fish stock in the pond type lake Warniak. III. Biomass and production of pike (Esox lucius L.) - Ekol. Pol. 21: 445-463.

Ciepielewski W. 1985 - Experimentally increased fish stock in the pond type lake Warniak (Poland). Changes of ichthyofauna between 1970 and 1983 - Ekol. Pol. 33: 37-59.

Commission Decision of 20 September 2013 establishing, pursuant to Directive 2000/60/EC of the European Parliament and of the Council, the values of the Member State monitoring system classifications as a result of the intercalibration exercise and repealing Decision 2008/915/EC. Official Journal of the European Union 2013/480/EU.

Conover G., Simmonds R., Whalen M. 2007 - Management and control plan for bighead, black, grass, and silver carps in the United States - Asian Carp Working Group, Aquatic Nuisance Species Task Force, Washington, D.C., 223 p.
Dąmbska I. 1969 - Charales of the lakes complex Wielkie Mamry - Bad. Fizjogr. nad Polską Zach. 22: 151-160 (in Polish with French summary)

de Jesus Raposo M.F., de Morais R.M.S.C., de Morais A.M.M.B. 2013 - Bioactivity and applications of sulphated polysaccharides from marine microalgae, a review - Mar. Drugs 11(1):233-252.

Deines A.M., Bunnell D.B., Rogers M.W., Beard Jr T.D., Taylor W.W. 2015 - A review of the global relationship among freshwater fish, autotrophic activity, and regional climate - Rev. Fish Biol. Fisher. 25(2): 323-336.

Desvilettes C., Bec A. 2009 - Formation and transfer of fatty acids in aquatic microbial food webs: Role of heterotrophic protists - In: Lipids in aquatic ecosystems (Eds) M.T. Arts, M.T. Brett, M.J. Kainz, Springer Dordrecht Heidelberg London New York, 25-43 p.

DIN EN 16695, 2015 - Water quality - Guidance on the estimation of phytoplankton biovolume - German version EN 16695:2015, Edition 2015-12 (Wasserbeschaffenheit - Anleitung zur Abschätzung des Phytoplankton-Biovolumens; Deutsche Fassung EN 16695:2015).

Dondajewska R., Kozak A., Kowalczewska-Madura K., Budzyńska A., Gołdyn R., Podsiadłowski S., Tomkowiak A. 2017 - The response of a shallow hypertrophic lake to innovative restoration measures - Uzarzewskie Lake case study - Ecol. Eng. DOI: 10.1016/j.ecoleng.2017.07.010.

Dunalska J.A., Grochowska J., Wiśniewski G., Napiórkowska-Krzebietke A. 2015 - Can we restore badly degraded urban lakes? - Ecol. Eng. 82: 432-441.

Dunst R.C., Born S.M., Uttormark P.D., Smith S.A., Nichols S.A., Peterson J.O., Knauer D.R., Serns S.L., Winter D.R., Wirth T.L. 1974 - Survey of lake rehabilitation techniques and experiences - Department of Natural Resources, Technical Bulletin No. 75, Madison, Wiscon$\sin$.

Effler S.W., Spada M.E., Gelda R.K., Peng F., Matthews D.A., Kearns C.M., Hairston N.G.Jr. 2015 - Daphnia grazing, the clear water phase, and implications of minerogenic particles in Onondaga Lake - Inland Waters 5(4): 317-330.

Eigemann F. 2013 - Allelopathic effects of submerged macrophytes on phytoplankton: determining the factors of phytoplankton sensitivity and detection of new modes of action - Dissertation, Berlin, $141 \mathrm{p}$.

Elliot J.A. 2012 - Is the future blue-green? A review of the current model predictions of how climate change could affect pelagic freshwater cyanobacteria - Water Res. 46(5): 1364-1371.

European Commission 2000 - Directive of the European Parliament and of the Council 2000/60/EC establishing a framework for community action in the field of water policy - Official Journal 2000 L 327/1, European Commission, Brussels, $72 \mathrm{p}$. 
Fei Y. 1989 - Chapter 5. Pond Culture of Food Fish - In: Integrated Fish Farming in China. Network of Aquaculture Centers in Asia and Pacific (NACA), Bangkok, Thailand. $278 \mathrm{p}$.

Gierałtowski M. 1967 - Acclimatization of herbivorous fish species in Poland - Gosp. Ryb. 1: 5-7 (in Polish).

Gołdyn R., Podsiadłowski S., Dondajewska R., Kozak A. 2014 - The sustainable restoration of lakes - towards the challenges of the Water Framework Directive - Ecohydrol. Hydrobiol. 14: 68-74.

Guiry M.D., Guiry, G.M. 2017 - AlgaeBase. World-wide electronic publication, National University of Ireland, Galway. http://www.algaebase.org; searched on 16 January 2017.

Guo C., Ye S., Lek S., Liu J., Zhang T., Yuan J., Li Z. 2013 The need for improved fishery management in a shallow macrophytic lake in the Yangtze River basin: Evidence from the food web structure and ecosystem analysis Ecol. Model. 267: 138-147.

Hayes M., Skomedal H., Skjånes K., Mazur-Marzec H., Toruńska-Sitarz A., Catala M., Isleten Hosoglu M., García-Vaquero M. 2017 - Microalgal proteins for feed, food and health - In: Microalgal-based biofuels and bioproducts. From Feedstock cultivation to end products. Edition 1 (Eds) C. Gonzalez-Fernandez, R. Munoz, Woodhead publishers Elesevier, 347-367.

Hillbricht-Ilkowska A., Kajak Z. 1986 - Parameters and indices useful in controlling functional and structural changes in lakes undergoing eutrophication - In: Monitoring of lake ecosystems (Ed.) A. Hillbricht-Ilkowska, Zesz. Nauk. PAN „Człowiek i Środowisko”, Wrocław, Warszawa, Kraków, Gdańsk, Łódź: 23-45 (in Polish, English summary).

Huang W., Chu H., Dong B., Hu M., Yu Y. 2015 - A membrane combined process to cope with algae blooms in water - Desalination 355: 99-109.

Huber-Pestalozzi G. 1983 - Das phytoplankton des Süßwassers. Systematik und Biologie. 7 Teil, 1 Häfte: Chlorophyceae (Grünalgen) Ordnung Chlorococcales - In: Die Binnengewässer Einzeldarstellungen aus der Limnologie und ihren Nachbargebieten (Ed.) A. Thienemann, E. Schweizerbart'sche Verlasbuchhandlung, Stuttgart, $1044 \mathrm{p}$.

Hussian A.M., Napiórkowska-Krzebietke A., Toufeek M.E.F., Abd El-Monem A.M., Morsi H.H. 2015 - Phytoplankton response to changes of physicochemical variables in Lake Nasser, Egypt - J. Elem. 20(4): 855-871.

Hutorowicz A., Zdanowski B. 1993 - Environmental and trophic conditions in Lake Pogubie Wielkie after disappearance of submerged macrophytes - Arch. Pol. Fish. 1(2): 125-143.

Hutorowicz A., Dziedzic J. 2008 - Long-term changes in macrophyte vegetation after reduction of fish stock in a shallow lake - Aquat. Bot. 88 (3): 265-272.
Jeppesen E., Meerhoff M., Davidson T.A., Trolle D., Søndergaard M., Lauridsen T.L., Bekliğlu M., Brucet S., Volta P., González-Bergonzoni I., Nielsen A. 2014 - Climate change impacts on lakes: an integrated ecological perspective based on a multi-faced approach with special focus on shallow lakes - J. Limnol. 73(S1): 88-111.

Jeppesen E., Søndergaard M., Lauridsen T.L., Davidson T.A., Liu Z., Mazzeo N., Trochine C., Özkan K., Jensen H.S., Trolle D., Starling F., Lazzaro X., Johansson L.S., Bjerring R., Liboriussen L., Larsen S.E., Landkildehus F., Egemose S., Meerhoff M. 2012 - Biomanipulation as a restoration tool to combat eutrophication: recent advances and future challenge - In: Advances in Ecological Research (Eds) U.J. GuyWoodward, J.O.G. Eoin, Academic Press: 411-488.

Jia J., Shia W., Chena Q., Lauridsen T.L 2017 - Spatial and temporal variations reveal the response of zooplankton to cyanobacteria - Harmful Algae 64: 63-73.

Jurkiewicz-Karnkowska E., Jakubik B., Lewandowski K. 2017 - Long-term changes in the malacofauna of the pond-type experimental Lake Warniak (Mazurian Lakeland, north-eastern Poland) - Folia Malacol. 25(1): 27-36.

Kaiser H.F. 1958 - The varimax criterion for analytic rotation in factor analysis - Psychometrika 23: 187-200.

Kaiser H.F. 1960 - The application of electronic computers to factor analysis - Educ. Psychol. Meas. 20: 141-151.

Kalinowska K., Napiórkowska-Krzebietke A., Bogacka-Kapusta E., Hutorowicz J., Pyka J., Stawecki K., Kapusta A., Chybowski Ł. 2017 - Microbial and classic food web components under ice in eutrophic lakes of different morphometry and fisheries management - Oceanol. Hydrobiol. St. 46(3): 271-282.

Karpiński A. 1994 - The changes of phosphorus concentration in water and bottom sediments of three eutrophic lakes - PhD thesis, Olsztyn, 72 p. (in Polish).

Kelly M. 2004 - International and European standards for algal-based monitoring - Oceanol. Hydrobiol. St. 33: 77-85.

Kerekes J. 1977 - The index of lake basin permanence - Int. Revue ges. Hydrobiol. Hydrogr. 62: 291-293.

Kirkağaç M.U. 2011 - The status of grass carp (Ctenopharyngodon idella, Valenciennes 1844) in Turkey - Ankara Üniv. Vet. Fak. Derg. 58: 217-221.

Kirkağaç M.U., Demir N. 2006 - The effects of grass carp (Ctenopharyngodon idella Val., 1844) on water quality, plankton, macrophytes and benthic macroinvertebrates in a Spring pond - Turk. J. Fish. Aquat. Sci. 6: 7-15.

Kobos J., Błaszczyk A., Hohlfeld N., Toruńska-Sitarz A., Krakowiak A., Hebel A., Stryk K., Grabowska M., Toporowska M., Kokociński M., Messyasz B., Rybak A., Napiórkowska-Krzebietke A., Nawrocka L., Pełechata A., Budzyńska A., Zagajewski P., Mazur-Marzec H. 2013 - 
Cyanobacteria and cyanotoxins in Polish freshwater bodies - Oceanol. Hydrobiol. St. 42(4): 358-378.

Komárek J., Anagnostidis K. 1999 - Cyanoprokaryota 1. Teil: Chroococcales - In: Süßwasserflora von Mitteleuropa (Ed.) A. Pascher, Gustaw Fischer Jena-Stuttgart-Lübeck Ulm, 548 p.

Komárek J., Anagnostidis K. 2005 - Cyanoprokaryota 2. Teil: Oscillatoriales - In: Süßwasserflora von Mitteleuropa (Ed.) A. Pascher, Gustaw Fischer Jena-Stuttgart-Lübeck Ulm, 759 p.

Kovač D.J., Simeunović J.B., Babić O.B., Mišan A.Č., Milovanović I. Lj. 2013 - Algae in food and feed - Food Feed Res. 40(1): 21-31.

Kowalczewski A., Rybak J.I. 1981 - Atmospheric fallout as a source of phosphorus for Lake Warniak - Ekol. Pol. 29: 63-71.

Kozak A., Gołdyn R., Dondajewska R. 2015 - Phytoplankton Composition and Abundance in Restored Maltański Reservoir under the Influence of Physico-Chemical Variables and Zooplankton Grazing Pressure - PLoS ONE 10(4): e0124738.

Krammer K., Lange-Bertalot H. 1986 - Bacillariophyceae 1. Teil: Naviculaceae - In: Süßwasserflora von Mitteleuropa (Ed.) A. Pascher, VEB Gustaw Fischer Verlag, Jena, 876 p.

Krammer K., Lange-Bertalot H. 1988 - Bacillariophyceae 2. Teil: Epithemiaceae, Surirellaceae - In: Süßwasserflora von Mitteleuropa (Ed.) A. Pascher, Gustaw Fischer Verlag, Stuttgart-New York, 596 p.

Krammer K., Lange-Bertalot H. 1991 - Bacillariophyceae 3. Teil: Centrales, Fragilariaceae, Eunotiaceae - In: Süßwasserflora von Mitteleuropa (Ed.) A. Pascher, Gustaw Fischer Verlag, Stuttgart-Jena, 576 p.

Krupska J., Pełechaty M., Pukacz A., Ossowski P. 2012 Effects of grass carp introduction on macrophyte communities in a shallow lake - Ocean. Hydrobiol. St. 41(1): 35-40.

Krzywosz T. 1997 - The effect of grass carp (Ctenopharyngodon idella Valenciennes, 1844) on the environment of selected lakes - Arch. Pol. Fish. 5: 5-38 (in Polish with English abstract and summary).

Krzywosz T., Krzywosz W., Radziej J. 1980 - The effect of grass carp (Ctenopharyngodon idella Val.) on aquatic vegetation and ichthyofauna of Lake Dgal Wielki - Ekol. Pol. 28: 433-450.

Krzywosz W. 1999 - Relationships between trophic indicators and phytoplankton composition, biomass and photosynthetic activity in small eutrophic lakes - Pol. J. Ecol. 47(1): 15-27.

Lembi C.A., Ritenour B.G., Iverson E.M., Forss E.C. 1978 The effects of vegetation removal by grass carp on water chemistry and phytoplankton in Indian ponds - Trans. Am. Fish. Soc. 107: 161-171.
Lorenzen C.J. 1967 - Determination of chlorophyll and pheo-pigments: spectrophotometric equations - Limnol. Oceanogr. 12: 343-346.

Lürling M., van Geest G., Scheffer M. 2006 - Importance of nutrient competition and allelopathic effects in suppression of the green alga Scenedesmus obliquus by the macrophytes Chara, Elodea and Myriophyllum Hydrobiologia 556: 209-220.

Lürling M., Waajen G., de Senerpont Domis L.N. 2016 - Evaluation of several end-of-pipe measures proposed to control cyanobacteria - Aquat. Ecol. 50: 499-519.

Malzahn A.M., Boersma M., Wiltshire K.H., Clemmesen C., Laakmann S. 2007 - Comparative nutritional condition of larval dab and lesser sandeel in a highly variable environment - Mar. Ecol. Prog. Ser. 334: 205-212.

Meerhoff M., Iglesias C., Teixeira-de Mello F., Clemente J.M., Jensen E., Lauridsen T.L., Jeppesen E. 2007 - Effects of habitat complexity on community structure and predator avoidance behaviour of littoral zooplankton in temperate versus subtropical shallow lakes - Freshwater Biol. 52: 1009-1021.

Mickiewicz M., Wołos A. 2014 - Administrative, legal, natural, and socioeconomic factors that impede the functioning and development of inland fisheries in Poland - Arch. Pol. Fish. 22: 281-288.

Moss B., Kosten S., Meerhoff M., Battarbee R.W., Jeppesen E., Mazzeo N., Havens K., Lacerot G., Liu Z., De Meester L., Paerl H., Scheffer M. 2011 - Allied attack: climate change and eutrophication - Inland Waters 1: 101-105.

Napiórkowska-Krzebietke A. 2004 - Long-term changes of phytoplankton in lakes Niegocin, Mamry Północne and Kirsajty - PhD thesis, Olsztyn, 141 p. (in Polish).

Napiórkowska-Krzebietke A. 2014 - Phytoplankton of artificial ecosystems - an attempt to assess water quality Arch. Pol. Fish. 22: 81-96.

Napiórkowska-Krzebietke A. 2015 - Cyanobacterial bloom intensity in the ecologically relevant state of lakes - an approach to Water Framework Directive implementation - Oceanol. Hydrobiol. St. 44(1): 97-108.

Napiórkowska-Krzebietke A. 2017 - Phytoplankton as a basic nutritional source in diets of fish - J. Elem. 22(3): 831-841.

Napiórkowska-Krzebietke A., Dunalska J. 2015 Phytoplankton-based recovery requirement for urban lakes in the implementation of the Water Framework Directive's ecological targets - Oceanol. Hydrobiol. St. 44(1): 109-119.

Napiórkowska-Krzebietke A., Dunalska J.A., Zębek E. 2017 Taxa-specific eco-sensitivity in relation to phytoplankton bloom stability and ecologically relevant lake state - Acta Oecol. 81: 10-21.

Napiórkowska-Krzebietke A., Hussian A.M., Abd El-Monem A.M., El-Far A.M. 2016 - The relationship between 
phytoplankton and fish in nutrient-rich shallow Lake Qarun, Egypt - Oceanol. Hydrobiol. St. 45(4): 539-553.

Napiórkowska-Krzebietke A., Hutorowicz A. 2012 Phytoplankton Assemblages in Fishponds Fed with Treated Wastewater - In: Phycological Reports: Current advances in algal taxonomy and its applications: phylogenetic, ecological and applied perspective (Eds) K. Wołowski, I. Kaczmarska, J.M. Ehrman, A.Z. Wojtal, Institute of Botany Polish Academy of Sciences, Kraków: 275-285.

Napiórkowska-Krzebietke A., Hutorowicz A. 2014 Phytoplankton in an ecological status assessment of the vendace-type Lake Dejguny (northeastern Poland) Arch. Pol. Fish. 22: 29-40.

Napiórkowska-Krzebietke A., Hutorowicz A. 2015 - The physicochemical background for the development of potentially harmful cyanobacterium Gloeotrichia echinulata J. S. Smith ex Richt - J. Elem. 20(2) 363-376.

Napiórkowska-Krzebietke A., Kobos J., 2016 - Assessment of the cell biovolume of phytoplankton widespread in coastal and inland water bodies - Water Res. 104:

Napiórkowska-Krzebietke A., Stawecki K., Pyka J.P., Hutorowicz J., Zdanowski B. 2013 - Phytoplankton in relation to water quality of a mesotrophic lake - Polish J. Environ. Stud. 22(3): 793-800.

Napiórkowska-Krzebietke A., Stawecki K., Pyka J.P., Zdanowski B., Zębek E. 2016 - Phytoplankton and the physicochemical background in an assessment of the ecological and trophic conditions in vendace-type lakes J. Elem. 21(1): 159-172.

Napiórkowska-Krzebietke A., Szostek A., Szczepkowska B., Błocka B. 2012 - Thermal and oxygen conditions in lakes under restoration following the removal of herbivorous and seston-filtering fish - Arch. Pol. Fish. 20: 39-50.

Naselli-Flores L., Padisák J., Dokulil M.T., Chorus I. 2003 Equilibrium/steady-state concept in phytoplankton ecology - Hydrobiologia 502 (Dev. Hydrobiol. 172): 395-403.

Ofir E., Heymans J.J., Shapiro J., Goren M., Spanier E., Gal G. 2017 - Predicting the impact of Lake Biomanipulation based on food-web modelling - Lake Kinneret as a case study - Ecol. Model. 348: 14-24.

Oleksowicz A.S. 1988 - The dynamics of algal communities in the Kashubian Lakes of different trophy - Torun, Rozprawy UMK, p. 84 (in Polish with English summary)

Opuszyński K. 1978 - The effect of silver carp (Hypophthalmichthys molitrix Val.) on eutrophication of carp pond environment. Part VII. Summary - Roczn. Nauk roln., H. 99: 127-151 (in Polish).

Opuszyński K. 1987 - The feedback effect between the eutrophication process and the changes in the fish associates. The theory of ichthyoeutrophication - Wiad. ekol. 33(1): 21-30 (in Polish).
Opuszyński K., Shireman J.V. 1995 - Herbivorous fishes: culture and use for weed management - CRC Press, Boca Raton, Florida, 223 p.

Padisák J., Borics G., Feher G., Grigorszky I., Oldal I., Schmidt A., Zambone-Doma Z. 2003 - Dominant species, functional assemblages and frequency of equilibrium phases in late summer phytoplankton assemblages in Hungarian small shallow lakes - Hydrobiologia 502 (Dev. Hydrobiol. 172): 157-168.

Padisák J., Crossetti L.O., Naselli-Flores L. 2009 - Use and misuse in the application of the phytoplankton functional classification: a critical review with updates Hydrobiologia 621: 1-19.

Parparov A., Gal G., Hamilton D., Kasprzak P., Ostapenia A. 2010 - Water Quality Assessment, Trophic Classification and Water Resources Management - J. Water Resource Prot. 2: 907-915.

Phillips G., Free G., Karottki I., Laplace-Treyture C., Maileht K., Mischke U., Ott I., Pasztaleniec A., Portielje R., Søndergaard M., Trodd W., Van Wichelen J. 2014 Phytoplankton classification systems of member states In: Annex A of Water Framework Directive Intercalibration Technical Report Central Baltic Lake Phytoplankton Ecological Assessment Methods (Ed.) S. Poikane, Publications Office of the European Union, Luxembourg, http://dx.doi.org/10.2788/73991.

Phillips G., Lyche-Solheim A., Skjelbred B., Mischke U., Drakare S., Free G., Järvinen M., de Hoyos C., Morabito G., Poikane S., Carvalho L. 2013 - A phytoplankton trophic index to assess the status of lakes for the Water Framework Directive - Hydrobiologia 704(1): 75-95.

Pielou E.C. 1966 - The measurement of diversity in different types of biological collections - J. Theor. Biol. 13: 131-144.

Pliński M., Picińska J., Targoński L. 1984 - Method defining the biomass of marine phytoplankton by means of computers - Zesz. Nauk. WBiNoZ Gdansk University, 10: 129-155 (in Polish).

Prejs A. 1973 - Experimentally increased fish stock in the pond type lake Warniak. IV. Feeding of introduced and autochthonous non-predatory fish - Ekol. Pol. 21: 465-504.

Pulina S., Brutemark A., Suikkanen S., Padedda B.M., Grubisic L.M., Satta C.T., Caddeo T., Farina P., Sechi N., Luglé A. 2016 - Effects of warming on a Mediterranean phytoplankton community - Web Ecol. 16: 89-92.

Radke R.J., Kahl U. 2002 - Effects of a filter-feeding fish [silver carp, Hypophthalmichthys molitrix (Val.)] on phytoand zooplankton in a mesotrophic reservoir: results from an enclosure experiment - Freshwater Biol. 47: 2337-2344.

Regulation 2016 - Regulation of the Minister of the Environment of 21 July 2016 on status classification of surface water bodies and environmental quality standards for 
priority substances - Official Journal of the Laws of 2016, Item 1187 (in Polish).

Reynolds C.S., Huszar V., Kruk C., Naselli-Flores L., Melo S. 2002 - Towards a functional classification of the freshwater phytoplankton - J. Plankton Res. 5: 417-428.

Rigosi A., Carey C.C., Ibelings B.W., Brookes J.D. 2014 - The interaction between climate warming and eutrophication to promote cyanobacteria is dependent on trophic state and varies among taxa - Limnol. Oceanogr. 59(1): 99-114.

Ritterbusch D., Argillier C., Arle J., Białokoz W., Birzaks J., Blabolil P., Breine J., Draszkiewicz-Mioduszewska H., Jaarsma N., Karottki I., Krause T., Kubečka J., Lauridsen T., Logez M., Maire A., Palm A., Peirson G., Ř́ha M., Szlakowski J., Virbickas T., Poikane S. 2017 - Water Framework Directive Intercalibration: Central-Baltic Lake Fish fauna ecological assessment methods; Part A: Descriptions of fish-based lake assessment methods EUR 28022 EN. DOI: 10.2791/084375

Rojo C., Álvarez-Cobelas M. 2003 - Are there steady state phytoplankton assemblages in the field? - Hydrobiologia 502 (Dev. Hydrobiol. 172): 3-12.

Rose S. 1972 - What about the white amur? A superfish or a supercurse? - Florida Naturalist: 156-157.

Rosińska J., Rybak M., Gołdyn R. 2017 - Patterns of macrophyte community recovery as a result of the restoration of a shallow urban lake - Aquat. Bot. 138: 45-52.

Salmaso N. 2003 - Life strategies, dominance patterns and mechanisms promoting species coexistence in phytoplankton communities along complex environmental gradients - Hydrobiologia 502 (Dev. Hydrobiol. 172): 13-36.

Sauvanet J., Bourdier G., Jouve L., Bec A., Desvilettes C. 2013 - Feeding of pike larvae (Esox lucius L.) in an alluvial river backwater: fatty acid as markers of two organic matter flows - Fundam. Appl. Limnol. 183(4): 337-350.

Sayer C.D., Davidson T.A., Rawcliffe R., Langdon P.G., Leavitt P.R., Cockerton G., Rose N.L., Croft T. 2016 - Consequences of Fish Kills for Long-Term Trophic Structure in Shallow Lakes: Implications for Theory and Restoration Ecosystems 19: 1289-1309.

Scheffer M., Carpenter S.R. 2003 - Catastrophic regime shifts in ecosystems: linking theory to observation - Trends Ecol. Evol. 18(12): 648-656.

Scheffer M., van Nes E.H. 2007 - Shallow lakes theory revisited: various alternative regimes driven by climate, nutrients, depth and lake size - Hydrobiologia 584(1): 455-466.

Scheffer M., Hosper S.H., Meijer M.L., Moss B., Jeppesen E. 1993 - Alternative equilibria in shallow lakes - Trends Ecol. Evol. 8: 275-279.

Scheffer M., Strile D., van Nes E.H., Hosper H. 2003 - Climatic effects on regime shifts in lakes: A reply - Limnol. Oceanogr. 48(3): 1353-1356.
Shannon C.E., Weaver W. 1949 - The mathematical theory of communication - Urbana.

Shields R.J., Lupatsch I. 2012 - Algae for aquaculture and animal feeds - Technikfolgenabschätzung - Theorie und Praxis 21(1): 23-37.

Shireman J.V., Hoyer M.V., Maceina M.J., Canfield D.E. 1985 - The water quality and fishery of Lake Baldwin, Florida: 4 years after macrophyte removal by grass carp In: Lake and Reservoir Management: Practical Apllication, Proceedings of the 4th. Annual Conference of the North American Lake Management Society: 201-206.

Sitarek M., Napiórkowska-Krzebietke A., Mazur R., Czarnecki B., Pyka J.P., Stawecki K., Olech M., Sołtysiak S., Kapusta A. 2017 - Application of Effective Microorganisms Technology as a lake restoration tool - A case study of Muchawka Reservoir - J. Elem. 22(2): 529-543.

Skov C., Lousdal O., Johansen P.H., Berg S. 2003 - Piscivory of $0+$ pike (Esox lucius L.) in a small eutrophic lake and its implication for biomanipulation - Hydrobiologia 506: 481-487.

Skov C., Nilsson P.A. 2007 - Evaluating stocking of YOY pike Esox lucius as a tool in the restoration of shallow lakes Freshwater Biol. 52(9): 1834-1845.

Smith V.H., Wood S.A., McBride C.G., Atalah J., Hamilton D.P., Abell J. 2016 - Phosphorus and nitrogen loading restraints are essential for successful eutrophication control of Lake Rotorua, New Zealand - Inland Waters 6: 273-283.

Sommer U., Gliwicz Z.M., Lampert W., Duncan A. 1986 The PEG-model of seasonal succession of planktonic events in freshwaters - Arch. Hydrobiol. 106: 433-71.

Søndergaard M., Lauridsen T.L., Johansson L.S., Jeppesen E. 2017 - Nitrogen or phosphorus limitation in lakes and its impact on phytoplankton biomass and submerged macrophyte cover - Hydrobiologia 795(1): 35-48.

Spodniewska I. 1975 - Effect of an experimentally changed fish stock on phytoplankton structure, biomass and production in the pond type Lake Warniak - Symp. Biol. Hung. 15: 103-108.

Spodniewska I., Hillbricht-Ilkowska A. 1973 - Experimentally increased fish stock in the pond type lake Warniak. VI. Biomass and production of phytoplanktonEkol. Pol. 21: 519-532.

Standard Methods for Examination of Water \& Wastewater 1999 - Am. Publ. Health ASN., New York.

Talling J.F. 2003 - Phytoplankton-zooplankton seasonal timing and the 'clear-water phase' in some English lakes Freshwater Biol. 48: 39-52.

Terech-Majewska E., Pajdak J., Siwicki A.K. 2016 - Water as a source of macronutrients and micronutrients for fish, with special emphasis on the nutritional requirements of two fish species: the common carp (Cyprinus carpio) and 
the rainbow trout (Oncorhynchus mykiss) - J. Elem. 21(3): 947-961.

Tõnno I., Künnap H., Nõges T. 2003 - The role of zooplankton grazing in the formation of 'clear-water phase' in a shallow charophyte-dominated lake - Hydrobiologia 506(1): 353-358.

Tunowski J. 2006 - The changes in structure and abundance of zooplankton under the influence of a large stock of bighead and silver carp in polymictic Lake Warniak Komun. Ryb. 1: 7-14 (in Polish).

Tunowski J. 2008 - Changes of zooplankton induced by fish pressure in chosen eutrophic lakes - In: The application of statistical methods in science research III, StatSoft Polska, Kraków: 393-404 (in Polish).

Utermöhl H. 1958 - Zur Vervollkommung der quantitativen Phytoplankton-Methodik - Mitt. internat. Verein. Limnol. 9: 1-38 (in German).

Vavilala S.L., D’Souza J.S. 2015 - Algal Polysaccharides and Their Biological Applications - In: Marine Algae Extracts: Processes, Products, and Applications, First Edition (Eds) S-K Kim, K. Chojnacka, Wiley-VCH Verlag GmbH \& Co. KGaA: 411-451.

Wang H.J., Wang H.Z., Liang X.M., Pan B.Z., Kosten S. 2016 - Macrophyte species strongly affects changes in C, N, and $\mathrm{P}$ stocks in shallow lakes after a regime shift from macrophyte to phytoplankton dominance - Inland Waters 6(3): 449-460.

Węgleńska T., Dusoge K., Ejsmont-Karabin J., Spodniewska I., Zachwieja J. 1979 - Effect of winter-kill and changing fish stock on the pond-type Lake Warniak - Ekol. Pol. 27(1): 39-70.

Welcomme R. 2016 - Inland Fisheries: Past, Present, and Future - In: Freshwater, Fish and the Future (Eds) W.W. Taylor, D.M. Bartley, C. I. Goddard, N.J. Leonard, R. Welcomme, Proceedings of the Global Cross-Sectoral Conference: 7-14.

Westlake D.F., Květ J., Szczepański A. 1998 - The production ecology of wetlands. The IBP synthesis - Cambridge University Press.

Westrick J.A., Szlag D.C., Southwell B.J., Sinclair J. 2010 A review of cyanobacteria and cyanotoxins removal/inactivation in drinking water treatment - Anal. Bioanal. Chem. 397: 1705-1714.

Wood S.A., Borges H., Puddick J., Biessy L., Atalah J., Hawes I., Dietrich D.R., Hamilton D.P. 2017 - Contrasting cyanobacterial communities and microcystin concentrations in summers with extreme weather events: insights into potential effects of climate change - Hydrobiologia 785: 71-89.

WoRMS Editorial Board 2017 - World Register of Marine Species - Available from http://www.marinespecies.org at VLIZ, accessed 2017-07-28.

Yu J., Liu Z., He H., Zhen W., Guan B., Chen F., Li K., Zhong P., Teixeira-de Mello F., Jeppesen E. 2016 - Submerged macrophytes facilitate dominance of omnivorous fish in a subtropical shallow lake: Implications for lake restoration - Hydrobiologia 775: 97-107.

Zachwieja J. 1972 - Long-term changes of physical-chemical properties of water in lakes under meteorological conditions - PhD thesis, Olsztyn, p. 50 (in Polish).

Zachwieja J. 1973 - Experimentally increased fish stock in the pond type Lake Warniak. 1. Physical and chemical conditions in lake water - Ekol. Pol. 21: 405-422

Zakęś Z., Szczepkowski M., Kapusta A., Różyński M., Stawecki K., Pyka J., Szczepkowska B., Wunderlich K., Kozłowski M., Kowalska A., Hopko M. 2015 - From aquaculture into the Wild. Developing alternative methods for managing predatory fish in lake fisheries - IFI Olsztyn, 224 p. (in Polish with English summary).

Zawisza J., Ciepielewski W. 1973 - Experimentally increased fish stock in the pond type lake Warniak. II. Changes of the autochthonous ichtyofauna due to the introduction of carp (Cyprinus carpio L.) and bream (Abramis brama (L.)) - Ekol. Pol. 21:423-444.

Zdanowski B., Hutorowicz A., Tunowski J., Świątecki A., Olejnik G., Krzywosz T., Białokoz W., Chybowski Ł., Krzywosz W., Błocka B., Hutorowicz J., Robak A., Prusik S., Koprowska L., Ciemiński J., Węgleńska T., Lewandowski K., Jurkiewicz-Karnkowska E. 1999 Ecological effects of long-term pressure of phytophagous and seston-feeding fish on the structure and functioning of the shallow Lake Warniak (Mazurian Lakeland, Poland) - Acta Hydrobiol. 41: 29-47 and Errata Acta Hydrobiol. 42(3/4): 347.

Zębek E., Napiórkowska-Krzebietke A. 2016 - Response of phytoplankton to protective-restoration treatments enhancing water quality in a shallow urban lake - Environ. Monit. Assess. 188: 623-638.

Zhou G., Zhao X., Bi Y., Hu Z. 2011 - Effects of silver carp (Hypophthalmichthys molitrix) on spring phytoplankton community structure of Three-Gorges Reservoir (China): results from an enclosure experiment - J. Limnol. 70(1): 26-32. 